\title{
Savannah River Site Environmental Report for 2003
}

Editor

Albert R. Mamatey
Technical Consultants

Pete Fledderman

Timothy Jannik 



\section{Acknowledgments}

- The editor acknowledges with deep appreciation the efforts of the following individuals, who (in addition to the chapter authors and compilers) conducted reviews for-and/or contributed valuable resources, information, or technical data to- the Savannah River Site Environmental Report for 2003.

$\begin{array}{llll}\text { Brent Blunt } & \text { Dave Filler } & \text { Janice Lawson } & \text { Linda Nass } \\ \text { Mike Boerste } & \text { Susie Grant } & \text { Sherrod Maxwell } & \text { Ross Natoli } \\ \text { Jim Bollinger } & \text { Lina Guanlao } & \text { Jack Mayer } & \text { Rick Page } \\ \text { Palmer Bowen } & \text { Alex Guanlao } & \text { Larry McCollum } & \text { Bill Payne } \\ \text { Sandra Boynton } & \text { Chuck Hunter } & \text { Ken McLeod } & \text { Kathy Petty } \\ \text { Dean Campbell } & \text { Laura Janecek } & \text { Frank Melendez } & \text { Fran Poda } \\ \text { Tiajuana Cochnauer } & \text { Paul Johns } & \text { Barry Myers } & \text { Jason Ward }\end{array}$

Environmental Advisory Committee:

Dr. Edgar Berkey - Vice President and Chief Quality Officer, Concurrent Technologies Corporation; Adjunct Professor of Environmental Engineering, University of Pittsburgh

Dr. Keros Cartwright - Principal Hydrogeologist, Illinois Geological Survey; Adjunct Professor of Geology, University of Illinois

Dr. Bernd Kahn - Director, Environmental Research Center; Professor Emeritus, Nuclear Engineering and Health Physics, Georgia Institute of Technology

Dr. Milton Russell - Senior Fellow, Joint Institute for Energy and Environment (a research collaboration of the University of Tennessee, Oak Ridge National Laboratory, and the Tennessee Valley Authority; Professor Emeritus of Economics, University of Tennessee

Dr. Bernard Sweeney - Director, Stroud Water Research Center, Pennsylvania; Adjunct Professor of Zoology, University of Pennsylvania

Dr. Gordon Wolman - Professor of Geography and Environmental Engineering, Johns Hopkins University

- $\quad$ Listed below are those who provided expert publications support.

$\begin{array}{llll}\begin{array}{l}\text { Steve Ashe, } \\ \text { Bruce Boulineau, }\end{array} & \text { Stephanie Doetsch, } & \text { Trish Baughman, Paula } & \text { Debbie Beckett (forms) } \\ \text { Tom Kotti, } & \text { Don Lechner, } & \text { Bragg, Cherry Glisson, } & \text { Gwen Collins, Berkie } \\ \text { Hugh Smith, } & \text { Lisa McCullough, } & \text { Bernadette Hobbs, } & \text { Meriweather, and } \\ \text { and Byron Williams } & \text { Michelle Norris, } & \text { Vivian McDuffie, and } & \text { Terry Witherspoon } \\ \text { (photography) } & \text { Shirley Priester, and } & \text { Pam Reeves (external } & \text { (customer service) } \\ \text { Janet Devore (layout) } & \text { Joan Toole (printing } & \text { web posting) } & \text { Lisa McCollough and } \\ & \text { and CD production) } & \text { Eleanor Justice } & \text { Joan Toole (quality } \\ & & \text { (illustrating) } & \text { assurance) }\end{array}$

- A special thanks to Mary Baranek for coordinating the DOE-SR review and approval process, which requires dedication and support from both DOE-SR and WSRC.

$\begin{array}{llll}\text { Ben Gould (DOE-SR) } & \text { Randy Collins (WSRC) } & \text { Larry DeWitt (WSRC) } & \text { Barbara Smith (WSRC) } \\ \text { Bill Taylor (DOE-SR) } & \text { Tom Coughenour } & \text { Wileva Dunar (WSRC) } & \text { Pam Rouse (WSRC) } \\ \text { Gail Whitney (DOE-SR) } & \text { (WSRC) } & \text { Bob Shankle (WSRC) } & \text { Cathie Witker (WSRC) }\end{array}$


- Thanks to John Aull, Karl Bergmann, Chuck Harvel, and Tracey Humphrey for providing computer hardware and software support.

- Marvin Stewart is acknowledged with appreciation for providing Internet expertise.

- Gratitude is expressed to the following for management, administrative, and other support:

$\begin{array}{llll}\text { Brenda Alejo } & \text { Bonnie Dillabough } & \text { Mike Hughes } & \text { Joyce Ray } \\ \text { Patricia Allen } & \text { Daryl Doman } & \text { David Hughey } & \text { Jeffrey Ritchie } \\ \text { Perry Allen } & \text { Janice Duke } & \text { Jay Hutchison } & \text { Katie Scott } \\ \text { Margaret Arnett } & \text { Roger Duke } & \text { Gale Jernigan } & \text { Ranae Sharpe } \\ \text { Lydia Bates } & \text { Mike Dukes } & \text { Alan Lawson } & \text { Mark Spires } \\ \text { Margie Batten } & \text { Sylvia Finklin } & \text { Bill Lewis } & \text { Dan Stewart } \\ \text { Connie Black } & \text { Kathie Goehle } & \text { Bob Lorenz } & \text { John Strack } \\ \text { Judi Bolen } & \text { Sonny Goldston } & \text { Bill Macky } & \text { Becky Sturdivant } \\ \text { Nancy Brown } & \text { June Hall } & \text { Jeanne Malanowski } & \text { John Thomas } \\ \text { Mike Burroughs } & \text { Calvin Hamilton } & \text { Tony Melton } & \text { Robbie Timmerman } \\ \text { Becky Chavous } & \text { Tyrone Hanberry } & \text { Ken Mishoe } & \text { Helen Villasor } \\ \text { Lynette Connelly } & \text { Tim Hartley } & \text { Ann Odom } & \text { Kat Williams } \\ \text { Roslyn Cooke } & \text { Jim Heffner } & \text { Wayne Pippen } & \\ \text { Janet Crawford } & \text { Jack Herrington } & \text { Christine Posey } & \\ \text { Sharon Crawford } & \text { Elouise Holmes } & \text { Caroline Rachels } & \end{array}$




\section{Preface}

The Savannah River Site Environmental Report for 2003 (WSRC-TR-2004-00015) is prepared for the U.S. Department of Energy (DOE) according to requirements of DOE Order 231.1, "Environment, Safety and Health Reporting," and DOE Order 5400.5, "Radiation Protection of the Public and Environment." The report's purpose is to

- present summary environmental data that characterize site environmental management performance

- confirm compliance with environmental standards and requirements

- highlight significant programs and efforts

- $\quad$ assess the impact of SRS operations on the public and the environment

This year's report reflects a continuing effort (begun in 2001) to streamline the document and thereby increase its cost effectiveness-without omitting valuable technical data. To that end each author will continue to work toward presenting results in summary fashion, focusing on historical trends. Complete data tables again are included on the $\mathrm{CD}$ inside the back cover of the report. The $\mathrm{CD}$ also features an electronic version of the report; an appendix of site, environmental sampling location, dose, and groundwater maps; and complete 2003 reports from a number of other SRS organizations.

SRS has had an extensive environmental monitoring program in place since 1951 (before site startup). In the 1950s, data generated by the onsite environmental monitoring program were reported in site documents. Beginning in 1959, data from offsite environmental surveillance activities were presented in reports issued for public dissemination. SRS reported onsite and offsite environmental monitoring activities separately until 1985, when data from both programs were merged into one public document. The Savannah River Site Environmental Report for 2003 is an overview of effluent monitoring and environmental surveillance activities conducted on and in the vicinity of SRS from January 1 through December 31, 2003. It is prepared by the Environmental Services Section (ESS) of Westinghouse Savannah River Company (WSRC). The "SRS Environmental Monitoring Plan" (WSRC-3Q1-2-1000) and the "SRS Environmental Monitoring Program" (WSRC-3Q1-2-1100) provide complete program descriptions and document the

\section{Report Available on Web}

Readers can find the SRS Environmental Report on the World Wide Web at the following address:

http://www.srs.gov/general/pubs/ERsum/index.html

To inquire about the report, please contact

J.D. Heffner, Manager

Environmental Monitoring and Analysis

Westinghouse Savannah River Company

Building 735-B

Aiken, SC 29808

Telephone: 803-952-6931

E-mail address: james.heffner@srs.gov

rationale and design criteria for the monitoring program, the frequency of monitoring and analysis, the specific analytical and sampling procedures, and the quality assurance requirements.

Variations in the environmental report's data content from year to year reflect changes in the routine program or difficulties encountered in obtaining or analyzing some samples. Examples of such problems include adverse environmental conditions (such as flooding or drought), sampling or analytical equipment malfunctions, and compromise of the samples in the preparation laboratories or counting room.

The following information should aid the reader in interpreting data in this report:

- Analytical results and their corresponding uncertainty terms generally are reported with up to three significant figures. This is a function of the computer software used and may imply greater accuracy in the reported results than the analyses would allow.

- Units of measure and their abbreviations are defined in the glossary (beginning on page 83) and in charts at the back of the report.

- The reported uncertainty of a single measurement reflects only the counting error-not other components of random and systematic error in the measurement process-so some results may imply a greater confidence than the determination would suggest.

- An uncertainty quoted with a mean value represents the standard deviation of the mean 
value. This number is calculated from the uncertainties of the individual results. For an unweighted mean value, the uncertainty is the sum of the variances for the individual values divided by the number of individual results squared. For a weighted mean value, the uncertainty is the sum of the weighted variances for the individual values divided by the square of the sum of the weights.

- All values represent the weighted average of all acceptable analyses of a sample for a particular analyte. Samples may have undergone multiple analyses for quality assurance purposes or to determine if radionuclides are present. For certain radionuclides, quantifiable concentrations may be below the minimum detectable activity of the analysis, in which case the actual concentration value is presented to satisfy DOE reporting guidelines.

- The generic term "dose," as used in the report, refers to the committed effective dose equivalent (50-year committed dose) from internal deposition of radionuclides and to the effective dose equivalent attributable to beta/gamma radiation from sources external to the body. 


\section{Contents}

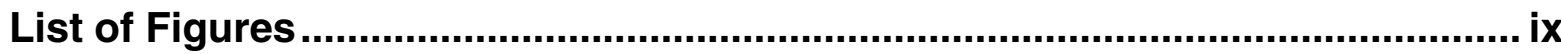

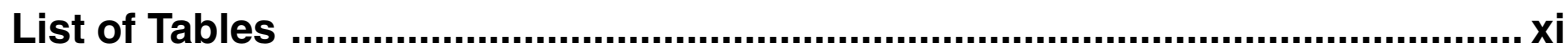

Acronyms and Abbreviations ............................................................................... Xii

Sampling Location Information ................................................................ xvii

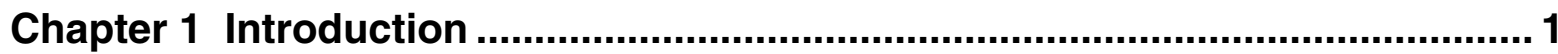

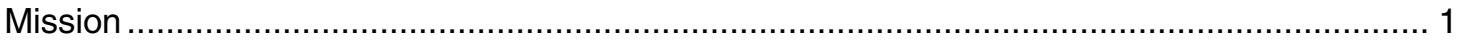

Site Location, Demographics, and Environment ............................................................ 1

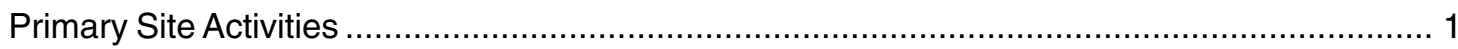

Chapter 2 Environmental Compliance .............................................................. 5

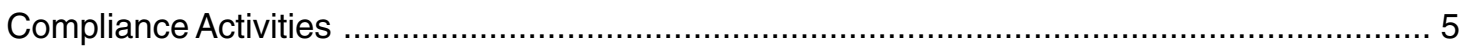

Environmental Release Response and Reporting .............................................................. 16

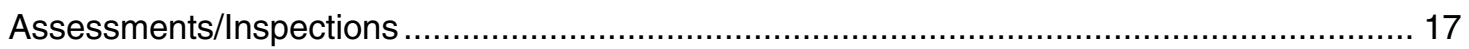

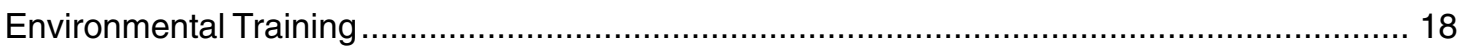

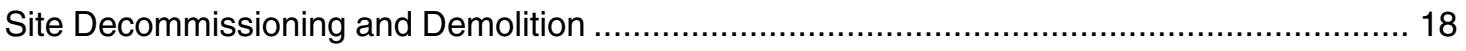

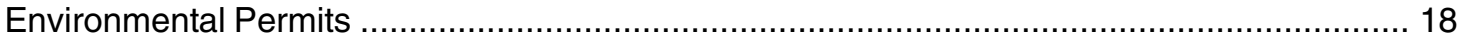

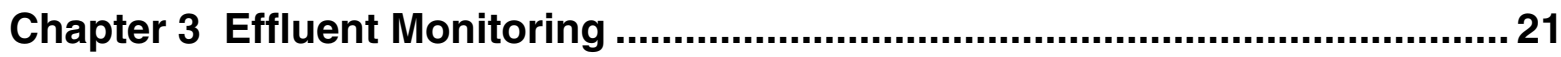

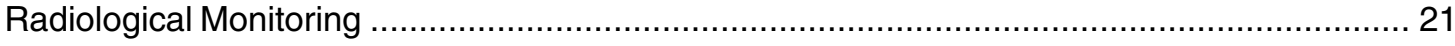

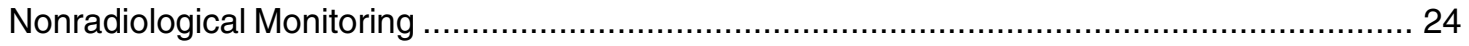

Chapter 4 Environmental Surveillance .......................................................... 29

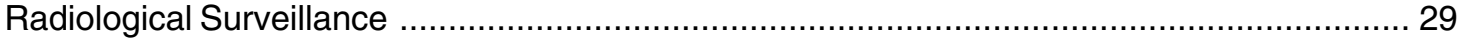

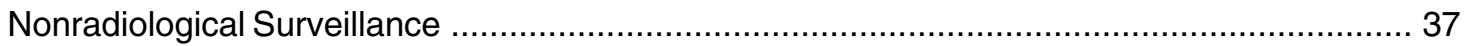

Chapter 5 Potential Radiation Doses …............................................................ 39

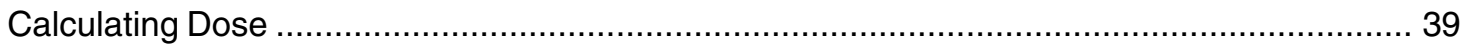

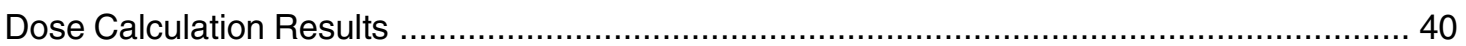




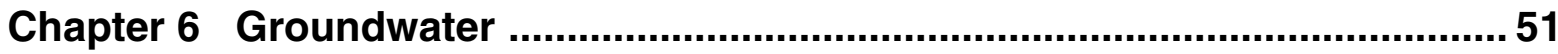

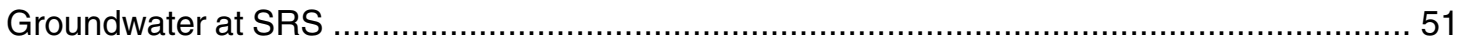

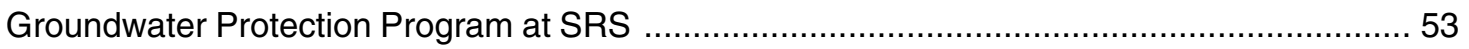

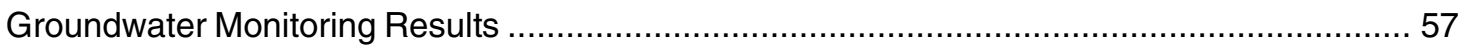

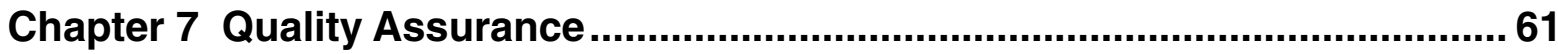

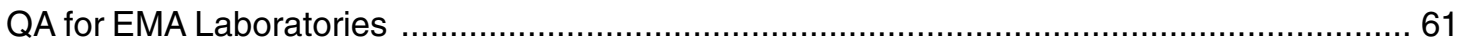

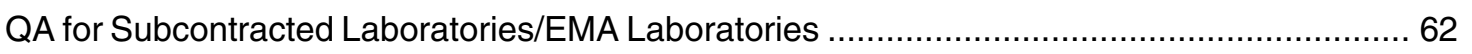

Appendix A Applicable Guidelines, Standards, and Regulations ...................67

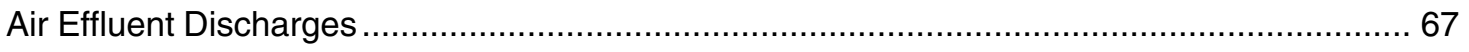

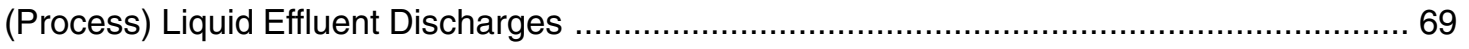

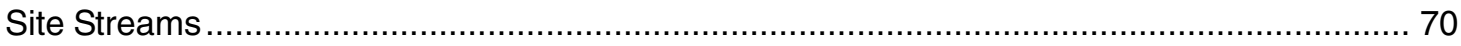

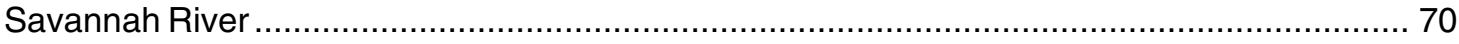

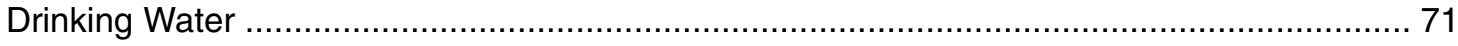

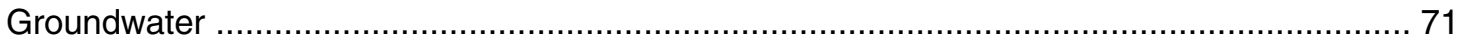

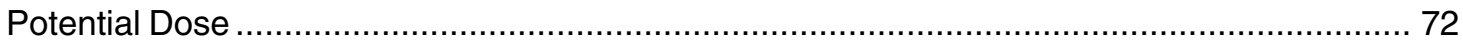

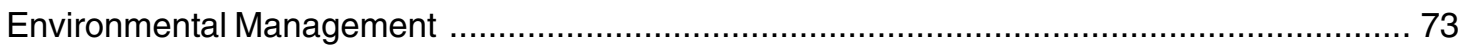

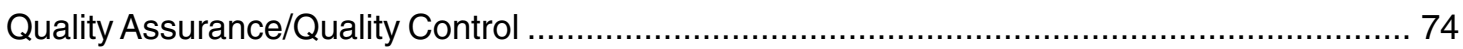

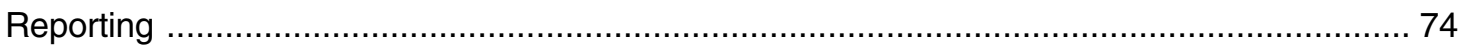

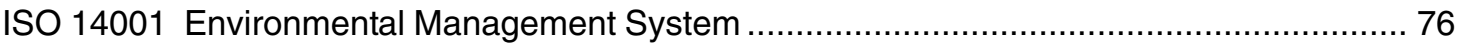

Appendix B Radionuclide and Chemical Nomenclature ..................................79

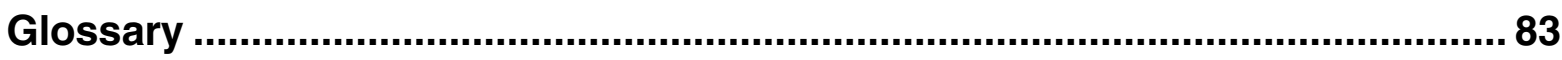

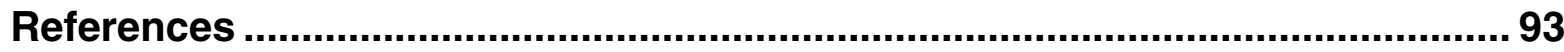




\section{List of Figures}

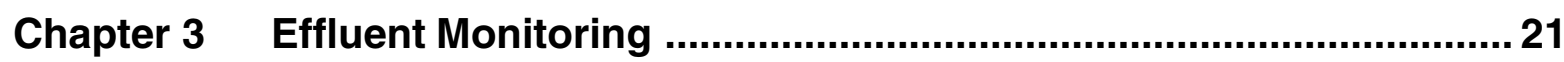

Figure 3-1 Ten-Year History of SRS Annual Atmospheric Tritium Releases ...................... 22

Figure 3-2 Ten-Year History of Direct Releases of Tritium to SRS Streams ...................... 24

Chapter 4 Environmental Surveillance ........................................................29

Figure 4-1 Tritium from SRS Seepage Basins and SWDF to Site Streams, 1994-2003 …...................................................................... 32

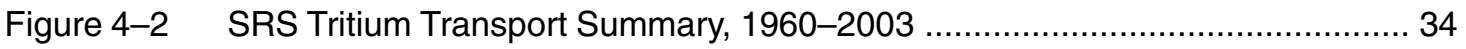

Chapter 5 Potential Radiation Doses ….......................................................... 39

Figure 5-1 Ten-Year History of SRS Maximum Potential All-Pathway Doses .................... 45

Figure 5-2 Ten-Year History of Savannah River Creek Mouth Fisherman's Dose ............. 48

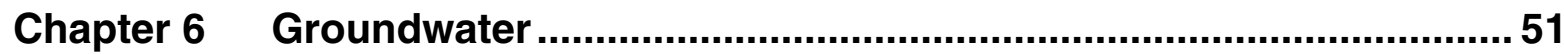

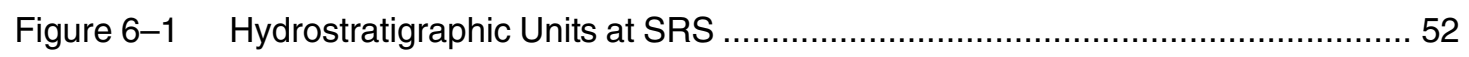

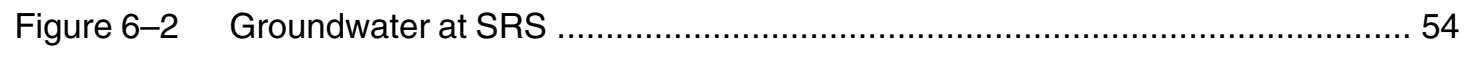

Appendix A Applicable Guidelines, Standards, and Regulations ...................67

Figure A-1 SRS EM Program QA/QC Document Hierarchy ...................................... 75 



\section{List of Tables}

Chapter 2 Environmental Compliance …........................................................ 5

Table 2-1 Some Key Regulations With Which SRS Must Comply .................................... 6

Table 2-2 SRS Reporting Compliance with Executive Order 12856 .................................. 8

Table 2-3 Types/Quantity of NEPA Activities at SRS During 2003 ................................... 9

Table 2-4 SRS Construction and Operating Permits, 1999-2003 .................................. 19

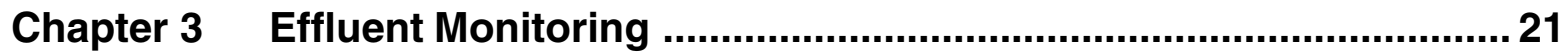

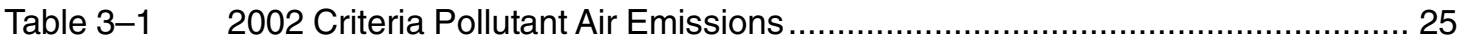

Table 3-2 SRS Power Plant Boiler Capacities …......................................................... 26

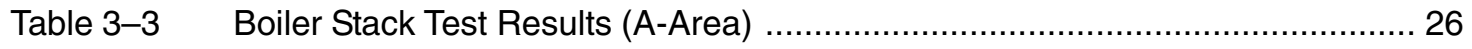

Table 3-4 2003 Exceedances of SCDHEC-Issued NPDES Permit

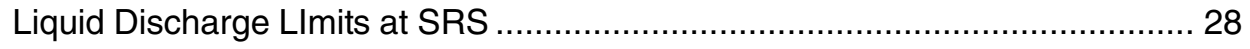

Chapter 5 Potential Radiation Doses ........................................................... 39

Table 5-1 2003 Radioactive Liquid Release Source Term and 12-Month Average Downriver Radionuclide Concentrations Compared to EPA's

Drinking Water Maximum Contaminant Levels (MCL)

Table 5-2 Potential Dose to the Maximally Exposed Individual from SRS

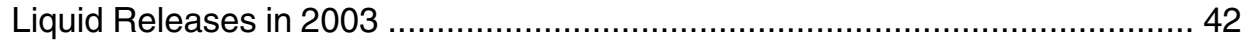

Table 5-3 Potential Dose to the Maximally Exposed Individual from SRS Atmospheric Releases in 2003.

Table 5-4 2003 Maximum Potential All-Pathway and Sportsman Doses Compared to the DOE All-Pathway Dose Standard.

Table 5-5 Potential Lifetime Risks from the Consumption of Savannah River Fish Compared to Dose Standards

Chapter 6 Groundwater

Table 6-1 Summary of Maximum Groundwater Monitoring Results for Major Areas Within SRS, 2002-2003 59

Chapter 7 Quality Assurance

Table 7-1 Subcontract Laboratory Performance in EPA Water Pollution Studies ............... 62

Table 7-2 Subcontract Laboratory Performance on Environmental Resource Associates (ERA) Standards 64

Appendix A Applicable Guidelines, Standards, and Regulations

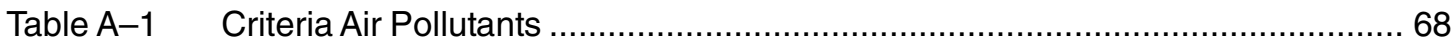

Table A-2 Airborne Emission Standards for SRS Coal-Fired Boilers ............................. 69

Table A-3 Airborne Emission Standards for SRS Fuel Oil-Fired Package Boilers ............. 69

Table A-4 South Carolina Water Quality Standards for Freshwaters .............................. 70 



\section{Acronyms and Abbreviations}

Note: Sampling location abbreviations can be found on page xvii.

A

AEC - U.S. Atomic Energy Commission

ALARA - As low as reasonably achievable

ANSP - Academy of Natural Sciences of Philadelphia

B

BCG - Biota concentration guide

BOD - Biological oxygen demand

BSRI - Bechtel Savannah River, Inc.

Btu - British thermal unit

C

CAA - Clean Air Act

CAAA - Clean Air Act Amendments of 1990

CAB - Citizens Advisory Board

CAS - Chemical abstract numbers

CBU - Closure Business Unit

CDC - Centers for Disease Control and Prevention

CERCLA - Comprehensive Environmental Response, Compensation, and Liability Act (Superfund)

CFC - Chlorofluorocarbon

CFR - Code of Federal Regulations

CIF - Consolidated Incineration Facility

CLED - Contaminated large-equipment disposition

CMP - Chemicals, metals, and pesticides

COU - Catalytic oxidation unit

CSRA - Central Savannah River Area

CSSX - Caustic side solvent extraction
CSWTF - Central Sanitary Wastewater Treatment Facility

C-TOX - Chronic toxicity

CWA - Clean Water Act

CX - Categorical exclusion

D

D\&D - Decommissioning and demolition

DCG - Derived concentration guide

DOE - U.S. Department of Energy

DOE/EML - U.S. Department of Energy

Environmental Measurements Laboratory

DOE-HQ - U.S. Department of Energy-

Headquarters

DOE-SR - U.S. Department of Energy-Savannah River Operations Office

DUS - Dynamic underground stripping

DWPF - Defense Waste Processing Facility

DWS - Drinking water standards

E

EA - Environmental assessment

ECA - Environmental compliance authority

EE/CA - Engineering evaluation/cost analysis

EGG - Environmental Geochemistry Group (now the Geochemical Monitoring group)

EIS - Environmental impact statement

EMA - Environmental Monitoring and Analysis group (formerly the Environmental Monitoring Section)

EMCAP - Environmental Monitoring Computer

Automation Program 
EMS - Environmental Monitoring Section of the Environmental Protection Department (of

Westinghouse Savannah River Company), now the Environmental Monitoring and Analysis group

EPA - U.S. Environmental Protection Agency

EPCRA - Emergency Planning and Community

Right-to-Know Act

EPD - Environmental Protection Department (of Westinghouse Savannah River Company), now the Environmental Services Section

ERA - Environmental Resource Associates

ERD - Environmental Restoration Division (now Soil and Groundwater Closure Projects)

ERDMS - Environmental Restoration Data Management System

ESCO - Energy Services Company

ESS - Environmental Services Section (formerly the Environmental Protection Department)

ETF - Effluent Treatment Facility

EST - Environmental Sciences and Technology

Department

$\mathbf{F}$

FDP - Facilities Disposition Projects (now Site

Decommissioning and Demolition

FFA - Federal Facility Agreement

FFCA - Federal Facility Compliance Agreement

FFCAct - Federal Facility Compliance Act

FONSI - Finding of no significant impact

FSSBU - Field Support Services Business Unit

G

GDNR - Georgia Department of Natural Resources

GIMS - Geochemical Information Management

System

GIS - Geographic Information System
GOCO - Government-owned, contractor-operated

GPMP - Groundwater Protection Management

Program Plan

GSMP - Groundwater Surveillance Monitoring

Program

GSA - General Separations Area

H

HBFC - Hydrobromofluorocarbon

HCFC - Hydrochlorofluorocarbon

HEAST - Health Effects Assessment Summary Tables (EPA)

HVAC - Heating, ventilation, and air conditioning

HWMF - Hazardous waste management facilities

ICRP - International Commission on Radiological Protection

ISO - International Organization for Standardization

$\mathbf{K}$

KAMS - K-Area materials storage

$\mathbf{L}$

LDR - Land disposal restrictions

LLD - Lower limit of detection

LLW - Low-level radioactive waste

M

MACT - Maximum achievable control technology

MAP - Mitigation action plan

MCL - Maximum contaminant level

MDA - Minimum detectable activity 
MDC - Minimum detectable concentration

MDL - Minimum detectable limit

MLLW - Mixed (i.e., hazardous and radioactive) lowlevel radioactive waste

MOX - Mixed oxide

MRD - Mean relative difference

mrem - Millirem

MWMF - Mixed Waste Management Facility

NCRP - National Council on Radiation Protection and Measurements

NELAC - National Environmental Laboratory Accreditation Conference

NEPA - National Environmental Policy Act

NESHAP - National Emission Standards for Hazardous Air Pollutants

NFN - No file negative

NHPA - National Historic Preservation Act

NIST - National Institute of Standards and Technology

NOV - Notice of violation

NPDES - National Pollutant Discharge Elimination System

NRC - Nuclear Regulatory Commission

NSPS - New Standards of Performance for Stationary Sources

NWP - Nationwide permit

0

ODS - Ozone-depleting substance

OBU - Operations Business Unit
PAR Pond - Pond constructed at Savannah River Site in 1958 to provide cooling water for P-Reactor and R-Reactor (P and R; hence, PAR)

PEIS - Programmatic environmental impact statement

pH - Measure of the hydrogen ion concentration in an aqueous solution (acidic solutions, $\mathrm{pH}$ from 0-6; basic solutions, $\mathrm{pH}>7$; and neutral solutions, $\mathrm{pH}=7$ )

ppm - Parts per million

PQL - Practical quantitation limit

Q

QA - Quality assurance

QAP - Quality Assurance Program (U.S. Department of Energy)

QA/QC - Quality assurance/quality control

QC - Quality control

$\mathbf{R}$

RBOF - Receiving Basin for Offsite Fuel

RCRA - Resource Conservation and Recovery Act

RFI/RI - RCRA facility investigation/remedial investigation

ROD - Record of decision

ROSRS - Remote-operations size-reduction system

$\mathbf{R Q}$ - Reportable quantity

RTF - Replacement Tritium Facility

$\mathbf{S}$

SARA - Superfund Amendments and Reauthorization Act

SCDHEC - South Carolina Department of Health and Environmental Control 
SCHWMR - South Carolina Hazardous Waste Management Regulations

SDWA - Safe Drinking Water Act

SEIS - Supplemental environmental impact statement

SES - Shealy Environmental Services, Inc.

S\&HO - Safety and Health Operations

SGCP - Soil and Groundwater Closure Projects

SIRIM - Site Item Reportability and Issues

Management

S\&M - Surveillance and maintenance

SRARP - Savannah River Archaeological Research

Program

SREL - Savannah River Ecology Laboratory

SRIP - Savannah River implementation procedure

SRL - Savannah River Laboratory (now Savannah River Technology Center)

SRS - Savannah River Site

SRTC - Savannah River Technology Center (formerly Savannah River Laboratory)

STP - Site treatment plan

SU - Standard unit

SUD - Site Utilities Division of Westinghouse Savannah River Company

SVE - Soil vapor extraction

SWD - Solid Waste Division (now Solid Waste and Infrastructure, a part of the Operations Business Unit)

SWDF - Solid Waste Disposal Facility
SW\&I - Solid Waste and Infrastructure (a part of Operations Business Unit; includes former Solid Waste Division)

SWMF - Solid Waste Management Facility

$\mathbf{T}$

TCLP - Toxicity Characteristic Leaching Procedure

TLD - Thermoluminescent dosimeter

TMDL - Total maximum daily load

TPBARS - Tritium-producing burnable absorber rods

TRU - Transuranic waste

TSCA - Toxic Substances Control Act

TSS - Total suspended solids

U

USFS-SR - U.S. Department of Agriculture Forest Service-Savannah River

USGS - U.S. Geological Survey

V

VIA - Values impact assessment

VOC - Volatile organic compound

W

WET - Whole effluent toxicity

WIPP - Waste Isolation Pilot Plant

WSRC - Westinghouse Savannah River Company 


\section{Sampling Location Information}

Note: This section contains sampling location abbreviations used in the text and/or on the sampling location maps. It also contains a list of sampling locations known by more than one name (see next page).

\begin{tabular}{ll}
$\begin{array}{ll}\text { Location } \\
\text { Abbreviation }\end{array}$ & Location Name/Other Applicable Information \\
\hline 4M & Four Mile \\
4MC & Four Mile Creek \\
BDC & Beaver Dam Creek \\
BG & Burial Ground \\
EAV & E-Area Vaults \\
FM & Four Mile \\
FMC & Four Mile Creek (Fourmile Branch) \\
GAP & Georgia Power Company \\
HP & HP (sampling location designation only; not an actual abbreviation) \\
HWY & Highway \\
KP & Kennedy Pond \\
L3R & Lower Three Runs \\
NRC & Nuclear Regulatory Commission \\
NSB L\&D & New Savannah Bluff Lock \& Dam \\
PAR & "P and R" Pond \\
PB & Pen Branch \\
RM & River Mile \\
SC & Steel Creek \\
SWDF & Solid Waste Disposal Facility \\
TB & Tims Branch \\
TC & Tinker Creek \\
TNX & Multipurpose Pilot Plant Campus \\
U3R & Upper Three Runs \\
&
\end{tabular}




\section{Sampling Locations Known by More Than One Name}

Augusta Lock and Dam; New Savannah Bluff Lock and Dam

Beaver Dam Creek; 400-D

Four Mile Creek-2B; Four Mile Creek at Road C

Four Mile Creek-6; Four Mile Creek at Road A-13-2

Lower Three Runs-2; Lower Three Runs at Patterson Mill Road

Pen Branch-3; Pen Branch at Road A-13-2

R-Area downstream of $R-1 ; 100-R$

River Mile 118.8; U.S. Highway 301 Bridge Area; Highway 301; US 301

River Mile 129.1; Lower Three Runs Mouth

River Mile 141.5; Steel Creek Boat Ramp

River Mile 150.4; Vogtle Discharge

River Mile 152.1; Beaver Dam Creek Mouth

River Mile 157.2; Upper Three Runs Mouth

River Mile 160.0; Dernier Landing

Steel Creek at Road A; Steel Creek-4; Steel Creek-4 at Road A; Steel Creek at Highway 125

Tims Branch at Road C; Tims Branch-5

Tinker Creek at Kennedy Pond; Tinker Creek-1

Upper Three Runs-4; Upper Three Runs-4 at Road A; Upper Three Runs at Road A; Upper Three Runs at Road 125

Upper Three Runs-1A; Upper Three Runs-1A at Road 8 


\section{Chapter 1}

\section{Introduction}

Pete Fledderman and Al Mamatey

Environmental Services Section

$\mathrm{T}$ HE Savannah River Site (SRS), one of the facilities in the U.S. Department of Energy (DOE) complex, was constructed during the early 1950s to produce basic materials (such as plutonium-239 and tritium) used in nuclear weapons. The site covers approximately 310 square miles in South Carolina and borders the Savannah River.

\section{Mission}

SRS's mission is to fulfill its responsibilities safely and securely in the stewardship of the nation's nuclear weapons stockpile, nuclear materials, and the environment. These stewardship areas reflect current and future missions to

- meet the needs of the enduring U.S. nuclear weapons stockpile

- $\quad$ store, treat, and dispose of excess nuclear materials safely and securely

- $\quad$ treat and dispose of legacy wastes from the Cold War and clean up environmental contamination

SRS will continue to improve environmental quality and clean up its legacy waste sites and manage any waste produced from current and future operations. Managing this waste will include working with DOE and the State of South Carolina to ensure that there is a safe and acceptable way to permanently dispose of high-level waste and nuclear materials off site and to find mutually acceptable solutions for disposition of waste.

\section{Site Location, Demographics, and Environment}

SRS covers 198,344 acres in Aiken, Allendale, and Barnwell counties of South Carolina. The site is approximately 12 miles south of Aiken, South Carolina, and 15 miles southeast of Augusta, Georgia.

The average population density in the counties surrounding SRS is about 91 people per square mile, with the largest concentration in the Augusta metropolitan area. Based on 2000 U.S. Census Bureau data, the population within a 50-mile radius of the center of SRS is approximately 712,780 .
Various industrial, manufacturing, medical, and farming operations are conducted near the site. Several major industrial and manufacturing facilities are located in the area, and a variety of crops is produced on local farms.

\section{Water Resources}

SRS is bounded on its southwestern border by the Savannah River for about 35 river miles and is approximately 160 river miles from the Atlantic Ocean.

The Savannah River is used as a drinking water supply source for some residents downriver of SRS. The river also is used for commercial and sport fishing, boating, and other recreational activities. There is no known use of the river for irrigation by farming operations downriver of the site.

\section{Land and Forest Resources}

The SRS region is part of the Southern Bottomland Hardwood Swamp region, which extends south from Virginia to Florida and west along the Gulf of Mexico to the Mississippi River drainage basin.

About 200 Carolina bays exist on SRS. These unique wetlands provide important habitat and refuge for many plants and animals.

\section{Animal and Plant Life}

Most of SRS has been virtually undisturbed for decades because of its isolation; this has facilitated a healthy, diverse ecosystem. About 260 species of birds, 60 species of reptiles, 40 species of amphibians, 80 species of freshwater fish, and 50 species of mammals exist on site.

\section{Primary Site Activities}

\section{Separations}

Originally, site facilities generated materials for nuclear weapons. Since the end of the Cold War in 1991, however, their purpose has shifted to the stabilization of nuclear materials from onsite and offsite sources to ensure safe long-term storage or disposal. 


\section{Spent Nuclear Fuel}

The site's spent nuclear fuel facilities house used fuel elements from reactors. These elements were generated during site reactor operations and also come from offsite sources.

\section{Tritium}

SRS tritium facilities recycle the tritium from nuclear weapons reservoirs that have been returned from service. This allows the United States to use its tritium supplies effectively and efficiently.

\section{Waste Management}

The site's waste management facilities manage

- the large volumes of radiological and nonradiological waste created by previous operations of the nuclear reactors and their support facilities

- $\quad$ newly generated waste created by ongoing site operations

Although the primary focus is on safely managing the high-level liquid waste, the site also must handle, store, treat, dispose of, and minimize solid waste resulting from past, ongoing, and future operations. Solid waste includes hazardous, low-level, mixed, sanitary, and transuranic wastes. More information about high-level and solid wastes is included on the CD housed inside the back cover of this report.

\section{Site Decommissioning and Demolition}

With the rapidly declining need for a large nuclear weapons stockpile, many SRS facilities no longer produce or process nuclear materials. They have become surplus and must be dispositioned safely and economically. Many of them are large and complex and contain materials that, if improperly handled or stored, could be hazardous. SRS faces a major task in the cleanup, reuse, safe storage, and demolition of these facilities. The Facilities Decommissioning Division (later the Facilities Disposition Projects) was established in 1996 to meet this challenge. In 2002, SRS began extensive decommissioning activities in D-Area, M-Area, and TNX. Site D\&D (decommissioning and demolition) - also known as $\mathrm{CH} 2 \mathrm{SRC}$, a subsidiary of $\mathrm{CH} 2 \mathrm{M}$ Hill-assumed and significantly expanded these responsibilities in 2003. More information about site D\&D activities is included on the $\mathrm{CD}$ accompanying this report.

\section{Soil and Groundwater Closure Projects}

The Soil and Groundwater Closure Projects (SGCP) organization is responsible for the closure of the 515 inactive waste units at SRS. In their closure efforts, SGCP personnel safely remove, stabilize, contain, or otherwise treat a contaminant so that it will not harm human health or the environment.

SGCP adopted an accelerated cleanup plan in 2003 through area-by-area closure and integration with Site D\&D. Area closures and integration with Site D\&D will complete remediation 14 years earlier than previously planned and will delete site areas from the Superfund's National Priorities List. T-Area is the first area scheduled for closure-in 2006. Work on the last waste unit in the SGCP program is scheduled for completion in 2025 .

\section{Environmental Monitoring}

SRS has always been concerned about the safety of the public. The site is committed to protecting human health and reducing the risks associated with past, current, and future operations. Sampling locations, sample media, sampling frequency, and types of analysis are selected based on environmental regulations, exposure pathways, public concerns, and measurement capabilities.

\section{Releases}

Releases to the environment of radioactive and nonradioactive materials come from legacy contamination as well as from ongoing site operations. For instance, shallow contaminated groundwater-a legacy-flows slowly toward onsite streams and swamps and into the Savannah River. In ongoing site operations, releases occur during the processing of nuclear materials.

Meeting certain regulations, such as the Safe Drinking Water Act and the Clean Air Act, requires that releases of radioactive materials from site facilities be limited to very small fractions of the amount handled. The site follows a philosophy that emissions (discharges) be kept far below the regulatory standards.

\section{Pathways}

The routes that contaminants can follow to get to the environment and then to people are known as exposure pathways. A person potentially can be exposed when he or she breathes the air, eats locally produced foods and milk, drinks water from the Savannah River, eats fish caught from the Savannah River, or uses the 
Savannah River for recreational activities such as boating, swimming, etc.

One way to learn if contaminants from the site have reached the environment is through environmental monitoring. The site gathers thousands of air, water, soil, sediment, food, vegetation, and animal samples each year. The samples are analyzed for potential contaminants released from site operations, and the potential radiation exposure to the public is assessed. Samples are taken at the points where materials are released from the facilities (effluent monitoring) and out in the environment (environmental surveillance).

\section{Research and Development}

The Savannah River Technology Center (SRTC) - the site's applied research and development laboratorycreates, tests, and implements solutions to SRS's technological challenges. Other environmental research is conducted at SRS by the following organizations:

- Savannah River Ecology Laboratory (SREL) More information can be obtained by contacting SREL at $803-725-2473$ or by viewing the laboratory's website at http://www.uga.edu/srel. Also, SREL's technical progress report for 2003 is included on the CD accompanying this document.

- U.S. Department of Agriculture Forest ServiceSavannah River (USFS-SR) - More information can be obtained by contacting USFS-SR at 803$725-0006$ or $803-725-0237$ or by viewing the USFS-SR website at http://www.srs.gov/general/ enviro/srfs.htm. Also, USFS-SR's 2003 report is included on the CD accompanying this document.

- Savannah River Archaeological Research Program (SRARP) - More information can be obtained by contacting SRARP at 803-725-3623. 



\section{Chapter 2}

\section{Environmental Compliance}

Dave Lester

Environmental Services Section
Contributing authors' names appear on page 19.

\section{Land Disposal Restrictions}

The 1984 RCRA amendments established Land Disposal Restrictions (LDRs) to minimize the threat of hazardous constituents migrating to groundwater sources. The same restrictions apply to mixed (hazardous and radioactive) waste.

Treatability variances are an option available to waste generation facilities if alternate treatment methods are appropriate for specific waste streams. SRS has identified three mixed waste streams that are potential candidates for a treatability variance. Because of special problems associated with radioactive components, these variances have been completed and sent to EPA, where they continue to await approval.

\section{Federal Facility Compliance Act}

The Federal Facility Compliance Act (FFCAct) was signed into law in October 1992 as an amendment to the Solid Waste Disposal Act to add provisions concerning the application of certain requirements and sanctions to federal facilities. A Site Treatment Plan (STP) consent order was obtained and implemented in 1995, as required by the FFCAct. A Statement of Mutual Understanding (SMU) for Cleanup Credits was executed in October 2003. The SMU allows SRS to earn credits for certain accelerated cleanup actions. Credits then can be applied to the STP commitments. SRS issued an annual update to the STP November 7, 2003, that identified changes in mixed waste treatment and inventory. STP updates will continue to be produced annually unless the consent order is modified.

\section{Underground Storage Tanks}

The 19 underground storage tanks at SRS that house petroleum products and hazardous substances, as defined by the Comprehensive Environmental Response, Compensation, and Liability Act (CERCLA), are regulated under Subtitle I of RCRA. These tanks require a compliance certificate annually from SCDHEC to continue operations. SCDHEC conducts an annual compliance inspection-and-records audit prior to issuing the compliance certificate. SCDHEC's 2003 inspection/audit found all 19 tanks to be in compliance. 
Table 2-1 Some Key Regulations With Which SRS Must Comply

Legislation What It Requires/SRS Compliance Status

RCRA

Resource Conservation and Recovery Act

FFCAct

Federal Facility Compliance Act

\section{CERCLA; SARA}

Comprehensive Environmental Response, Compensation, and Liability Act (1980);

Superfund Amendments and

Reauthorization Act (1986)

CERCLA/Title III (EPCRA)

Emergency Planning and Community

Right-to-Know Act (1986)

\section{NEPA}

National Environmental Policy Act (1969)

SDWA

Safe Drinking Water Act (1974)

CWA: NPDES

Clean Water Act (1977); National Pollutant

Discharge Elimination System

CAA; NESHAP

Clean Air Act (1970); National Emission

Standards for Hazardous Air Pollutants
The management of hazardous and nonhazardous wastes and of underground storage tanks containing hazardous substances and petroleum products - In compliance

The development by DOE of schedules for mixed waste treatment to avoid waiver of sovereign immunity and to meet LDR requirements - In compliance

The establishment of liability, compensation, cleanup, and emergency response for hazardous substances released to the environment - In compliance

The reporting of hazardous substances used on site (and their releases) to EPA, state, and local planning units - In compliance

The evaluation of the potential environmental impact of federal activities and alternatives - In compliance

The protection of public drinking water systems - In compliance

The regulation of liquid discharges at outfalls (e.g., drains or pipes) that carry effluents to streams - In compliance

The establishment of air quality standards for criteria pollutants, such as sulfur dioxide and particulate matter, and hazardous air emissions, such as radionuclides and benzene, - In compliance

The regulation of use and disposal of PCBs - In compliance

Toxic Substances Control Act (1976)

ties of residual waste could remain in high-level waste tanks was inconsistent with the Nuclear Waste Policy Act. DOE is pursuing judicial and legislative remedies, but until such a process is available, grouting and closure of tanks $18 \mathrm{~F}$ and $19 \mathrm{~F}$ cannot take place. The next action for these tanks is grouting and closure.

In addition to the work being completed on Tanks $18 \mathrm{~F}$ and $19 \mathrm{~F}$, closure activities started for the $1 \mathrm{~F}$ evaporator system. Current plans are to have waste removal and characterization of the $1 \mathrm{~F}$ evaporator system completed in order to grout in sequence with tanks $18 \mathrm{~F}$ and 19F. Upon completion, this would be the first high-level waste evaporator system to be closed in the DOE complex. 


\section{Waste Minimization Program}

The SRS Waste Minimization Program is part of a broad, ongoing effort to prevent pollution and minimize waste on site. The program is designed to meet the requirements of RCRA, of DOE orders, and of applicable executive orders. At SRS, all operations are concerned with increasing pollution prevention awareness and successes. Pollution Prevention (P2) is integral to the SRS Environmental Management Policy, Environmental Management System (EMS), and Safety Management System (SMS). SRS embraces pollution prevention as a primary strategy to operate in a compliant, cost-effective manner that protects the environment and the safety and health of employees and the public. The P2 Program strives to (1) reduce employee exposure to toxic and radioactive materials and (2) mitigate environmental impacts of site operations. In the process, these activities help reduce the costs of operations. SRS's P2 Program establishes the environmental management preference of source reduction and recycling over treatment, storage, and disposal—and the preferred use of energy efficient and resource conservative practices and operations.

Each year, DOE recognizes its top achievers in the area of pollution prevention (P2) through the DOE National P2 Awards Program. SRS has done well historically in competing for this recognition. The SRS P2 Program continues to distinguish itself as a nationally recognized leader in 2003, with SRS teams winning four of the $14 \mathrm{DOE}$ award categoriesBio-based Products, Education and Outreach, Waste/ Pollution Avoidance, and Hazardous/Radioactive Recycling.

\section{P2 Program Results}

SRS completed 81 documented P2 initiatives in 2003, resulting in a total annualized solid waste avoidance of $4,337 \mathrm{~m}^{3}$ and cost avoidance of $\$ 57$ million. This represents a greater than 10:1 return on program investment over the life of the project, and exceeds the P2 Program target goal by 175 percent.

SRS also has active industrial and office waste recycling programs, having achieved a recycle rate of 41 percent $(1,036$ metric tons recycled) of office-type sanitary waste in 2003 and a 27-percent recycle rate $(4,725$ metric tons) of the total sanitary waste stream, including industrial waste.

\section{Comprehensive Environmental Response, Compensation, and Liability Act}

SRS was placed on the National Priority List in December 1989, under the legislative authority of CERCLA (Public Law 96-510), as amended by the Superfund Amendments and Reauthorization Act of 1986 (SARA, Public Law 99-499). In accordance with Section 120 of CERCLA, DOE, EPA Region IV, and SCDHEC entered into the Federal Facility Agreement (FFA), which became effective August 16, 1993.

SRS has 515 waste units in the Soil and Groundwater Closure Projects program. At the end of 2003, remediation was in progress, or had been completed, in 335 units and areas ( 300 complete and 35 in the remediation phase). Closure activities during 2003 included the following:

- Remedial Investigations (RIs) were initiated on the Fourmile Branch Integrator Operable Unit (IOU), Pen Branch IOU, and Upper Three Runs IOU.

- A RCRA Facility Investigation/Remedial Investigation (RFI/RI) was initiated on the M-Area settling basin inactive process sewers to manhole 1.

- Remedial actions were initiated at the A-Area miscellaneous rubble pile, Ford Building seepage basin, L-Area Reactor seepage basin, L-Area rubble pile, L-Area burning/rubble pit, L-Area gas cylinder disposal facility, three R-Area Bingham pump outage pits, and three R-Area unknowns.

- Remedial actions were completed and post-construction reports/final remediation reports were submitted for two A-Area burning/ rubble pits, A-Area rubble pit, Ford Building seepage basin, and L-Area Reactor seepage basin.

- An interim action post-construction report was submitted for the Old Radioactive Waste Burial Ground (solvent tanks).

- Removal actions were initiated for the C-Area ash pile off Powerline Road and C-Area ash pile.

- Records of Decision (RODs) were submitted to the regulators for their review and comments for the L-Area hot shop, sandblast area CML-003, six R-Area Reactor seepage basins, R-Area overflow basin, Road A chemical basin, TNX 
Table 2-2 SRS Reporting Compliance with Executive Order 12856

\begin{tabular}{lll}
\hline $\begin{array}{l}\text { EPCRA } \\
\text { Citation }\end{array}$ & $\begin{array}{l}\text { Activity } \\
\text { Regulated }\end{array}$ & $\begin{array}{c}\text { Reported per } \\
\text { Applicable } \\
\text { Requirement }\end{array}$ \\
\hline $302-303$ & Planning Notification & Not Required a \\
304 & Extremely Hazardous Substances & Not Required a \\
$311-312$ & Release Notification & Yes \\
313 & $\begin{array}{l}\text { Material Safety Data Sheet/ } \\
\text { Chemical Inventory }\end{array}$ & Yes \\
\hline$\quad$ Not required to report under provisions of “Executive Order 12856 and SARA Title III Reporting Requirements
\end{tabular}

burying ground, new TNX seepage basin, old TNX seepage basin, and TNX groundwater.

- RODs received project manager approval in preparation for submittal to EPA, SCDHEC, and DOE for agreement signatures for the A-Area miscellaneous rubble pile, two Central Shops burning/rubble pits, L-Area hot shop, sandblast area CML-003, three R-Area Bingham pump outage pits, three R-Area unknowns, Road A chemical basin, TNX burying ground, new TNX seepage basin, old TNX seepage basin, and TNX groundwater.

- Final agency agreements were obtained, and RODs were issued for the P-Area burning/rubble pit, General Separations Area consolidation unit, R-Area acid/caustic basin, L-Area rubble pile, L-Area burning/rubble pit, L-Area gas cylinder disposal facility, three R-Area Bingham pump outage pits, three R-Area unknowns, two Central Shops burning/rubble pits, and the A-Area miscellaneous rubble pile.

- ROD amendments were approved for seven chemical, metals, and pesticide pits.

- An explanation of significant difference was approved for three P-Area reactor seepage basins.

- Site evaluation reports were submitted for 16 site evaluation areas.

A listing of all waste units at SRS can be found in appendix C ("RCRA/CERCLA Units List") and appendix G ("Site Evaluation List") of the FFA.

\section{Emergency Planning and Community Right-to-Know Act}

The Emergency Planning and Community

Right-to-Know Act (EPCRA) of 1986 requires facilities to notify state and local emergency planning entities about their hazardous chemical inventories and to report releases of hazardous chemicals. The Pollution Prevention Act of 1990 expanded the Toxic Chemical Release Inventory report to include source reduction and recycling activities.

\section{Tier II Inventory Report}

Under Section 312 of EPCRA, SRS completes an annual Tier II Inventory Report for all hazardous chemicals present at the site in excess of specified quantities during the calendar year. Hazardous chemical storage information is submitted to state and local authorities by March 1 for the previous calendar year.

\section{Toxic Chemical Release Inventory Report}

Under Section 313 of EPCRA, SRS must file an annual Toxic Chemical Release Inventory report by July 1 for the previous year. SRS calculates chemical releases to the environment for each regulated chemical that exceeds its established threshold, and reports the release values to EPA on Form $\mathrm{R}$ of the report.

The Form R for 2003 identified 13 chemicals, with releases totaling 234,636 pounds. As in 2002, nitrate, chromium, and zinc compounds were the largest contributors to the total reportable releases in 2003. 


\section{Executive Order 12856}

Executive Order 12856, "Federal Compliance with Right-to-Know Laws and Pollution Prevention Requirements," requires that all federal facilities comply with right-to-know laws and pollution prevention requirements. SRS complies with the applicable reporting requirements for EPCRA, as indicated in table $2-2$, and the site incorporates the toxic chemicals on the Toxic Release Inventory report into its pollution prevention efforts.

\section{National Environmental Policy Act}

The National Environmental Policy Act (NEPA) establishes policies and goals for the protection, maintenance, and enhancement of the human environment in the United States. NEPA provides a means to evaluate the potential environmental impact of major federal activities that could significantly affect the quality of the environment and to examine alternatives to those actions.

In 2003, 250 reviews of newly proposed actions were conducted at SRS and formally documented. The types and numbers of NEPA activities conducted on site in 2003 are presented in table 2-3. Among the specific activities were the following:

- A Programmatic Environmental Assessment (PEA) (DOE/EA-1393) and a signed Finding of No Significant Impact (FONSI) were completed to analyze the potential environmental impacts of the implementation of a long-term comprehensive

\section{Table 2-3 Types/Quantity of NEPA Activities at SRS during 2003}

\begin{tabular}{lr}
\hline Type of NEPA Documentation & Number \\
\hline Categorical Exclusion & 227 \\
Tiered to Previous NEPA Documentation & 20 \\
Environmental Assessment & 3 \\
Programmatic Environmental Assessment & 1 \\
Engineering Evaluation/Cost Analysis & 2 \\
Environmental Impact Statement & 4 \\
Supplemental Environmental & 1 \\
Impact Statement & \\
Programmatic Environmental & 1 \\
Impact Statement &
\end{tabular}

Total

a Nine of the 259 NEPA activities were carryovers from 2002, leaving 250 newly proposed actions in 2003. management program for potentially reusable low enriched uranium, natural uranium, and depleted uranium.

- A revised FONSI was issued for transportation of radioactive waste across SRS. The proposed action was transporting commercial shipments of low-level waste across SRS to the disposal facility in Barnwell, South Carolina, using the SRS rail and road systems. Specifically, the action dealt with allowing Southern California Edison to transport the decommissioned San Onofre reactor vessel to Barnwell.

- A revised FONSI was issued for the expansion and operation of the SRS Central Shops borrow pit. The proposed action involved the expansion and operation of part of the borrow pit to allow for the cost-effective disposal of inert construction and demolition debris that had been going to the Three Rivers Solid Waste Authority Regional Landfill.

- An amended Record of Decision (ROD) was issued for the Interim Management of Nuclear Materials Environmental Impact Statement (EIS). The proposed action was for DOE to dispose of certain material, including cobalt-60 and thulium-170, as waste, and to compare the materials and disposal technologies evaluated in the SRS Waste Management EIS (DOE/EIS0217) and the Interim Management of Nuclear materials EIS (DOE/EIS-0220).

- An amended ROD was issued for changes needed to the surplus plutonium disposition program. A Supplement Analysis (DOE/EIS-0283-SA1) supporting the amended ROD evaluates the impacts of making plutonium feed from the Mixed Oxide Fabrication Facility from approximately 6.5 tons of plutonium material originally intended for immobilization.

\section{Safe Drinking Water Act}

The federal Safe Drinking Water Act (SDWA) was enacted in 1974 to protect public drinking water supplies. SRS drinking water is supplied by 18 separate systems, all of which utilize groundwater sources. The A-Area, D-Area, and K-Area systems are actively regulated by SCDHEC, while the remaining 15 site water systems receive sporadic regulatory inspections.

Samples are collected and analyzed periodically by SRS and SCDHEC to ensure that all site domestic water systems meet SCDHEC and EPA bacteriological and chemical drinking water quality standards. All samples collected in 2003 met these standards. 
The B-Area Bottled Water Facility is listed as a public water system by SCDHEC. Results from quarterly bacteriological analyses and annual complete chemical analyses performed in 2003 met SCDHEC and FDA water quality standards. The bottled water facility is not subject to the lead and copper requirements.

SCDHEC conducted its survey of the A-Area, D-Area, and K-Area domestic water systems in March 2003. Survey results indicated a "satisfactory" rating.

SRS received no NOVs in 2003 under the SDWA.

\section{Clean Water Act}

\section{National Pollutant Discharge Elimination System}

The Clean Water Act (CWA) of 1972 created the National Pollutant Discharge Elimination System (NPDES) program, which is administered by SCDHEC under EPA authority. The program is designed to protect surface waters by limiting releases of nonradiological effluents into streams, reservoirs, and wetlands.

SRS had three NPDES permits in 2003, as follows:

- One permit for industrial wastewater discharge (SC0000175)

- $\quad$ Two general permits for stormwater discharge (SCR000000 for industrial and SCR100000 for construction)

More information about the NPDES permits can be found in chapter 3, "Effluent Monitoring."

The results of monitoring for compliance with the industrial wastewater discharge permit were reported to SCDHEC in the monthly discharge monitoring reports, as required by the permit.

During October, SCDHEC conducted its annual 2-week audit of the SRS NPDES permitted outfalls. Overall, SRS received one noncompliance rating for this audit. The rating was issued primarily for problems involving flow measurements at one NPDES outfall. Additional information about this audit is contained in the "Assessments/Inspections" section of this chapter, beginning on page 16).

The outfalls covered by the industrial stormwater permit (SCR000000) were reevaluated in 2002. This resulted in the development of a new sampling plan, which was implemented in 2003.

Under the Code of Federal Regulations (CFR) Oil Pollution Prevention regulation (40 CFR 112), SRS must report petroleum product discharges of 1,000 gallons or more into or upon the navigable waters of the United States, or petroleum product discharges in harmful quantities that result in oil sheens. No such incidents occurred at the site during 2003.

SRS has an agreement with SCDHEC to report petroleum product discharges of 25 gallons or more to the environment. One such incident in this category occurred at the site during 2003. This involved a 40-gallon diesel fuel leak from a commercial truck fuel line traveling across the site on a state road (not associated with SRS operations), and it was reported appropriately. The diesel fuel was leaked onto the road surface and was cleaned up by site personnel without entering any watersheds or endangering the environment.

A consent order was signed December 15, 2003, between SRS and SCDHEC to prevent permit limit exceedances for mercury at the F-08 outfall. The revised NPDES permit required SRS to meet stringent mercury limits beginning in December 2003. This innovative, "up-front" consent order provided SRS 5 years for compliance with mercury limits, which is the same time provided in the NPDES permit to meet other metals limits. The consent order required implementation of a Mercury Minimization Plan, which has been submitted to SCDHEC and is awaiting approval.

\section{Notices of Violation (NPDES)}

SRS's 2003 compliance rate for the NPDES program under the CWA was 99.8 percent. One NOV was issued to the site during 2003 in association with the NPDES program.

SRS received an NOV from SCDHEC September 29 for permit exceedances for copper and lead at the F08 NPDES outfall. The copper and lead levels were attributed to flush water from jet cleaning at a process water well within the facility. The site has discontinued well cleaning activities until an acceptable method can be evaluated to ensure that future cleaning activities do not result in a permit violation. No further action was required by SCDHEC.

Ten exceedances at NPDES outfalls occurred at SRS in 2003. A list of these-including outfall locations, probable causes, and corrective actions - can be found in chapter 3 (table 3-4). Seven of the exceedances were for chronic toxicity or acute toxicity at outfalls A-01, A-11 and G-10. Two toxicity exceedances at outfall A-11 were attributed to high amounts of suspended solids resulting from excessive rains just prior to sampling. Four exceedances, at outfalls A-01, A-11 and G-10, were the result of unhealthy breeding 
stocks at the subcontract laboratory performing the analyses. The inability of the laboratory cultures to survive and multiply resulted in invalid tests. Dietary improvements were made to the breeding stock, eliminating the problem. The final toxicity exceedance occurred at the A-11 outfall. No cause for the failure has been determined and subsequent analyses of the discharge failed to identify the presence of a toxicant in the effluent. As previously noted, three metals exceedances occurred at the $\mathrm{F}-08$ outfall, resulting in an NOV from SCDHEC.

\section{Dredge and Fill; Rivers and Harbors}

The CWA, Section 404, "Dredge and Fill Permitting," as amended, and the Rivers and Harbors Act, Section 9 and 10," Construction Over and Obstruction of Navigable Waters of the United States," protect U.S. waters from dredging and filling and construction activities by the permitting of such projects. Dredgeand-fill operations in U.S. waters are defined, permitted, and controlled through implementation of federal regulations in $33 \mathrm{CFR}$ and $40 \mathrm{CFR}$.

In 2003, SRS conducted activities under five Nationwide Permits (NWPs) as part of the NWP program (general permits under Section 404), but under no individual Section 404 permits. The activities were as follows:

- Dam construction on an unnamed tributary to Fourmile Branch for the Mixed Waste Management Facility Groundwater Interim Measures project was conducted under NWP-38, "Hazardous Waste Cleanup." Mitigation for the impact to wetlands must be addressed before the permit can be considered closed.

- The plugging of ditches and the removal of undesirable vegetation in 16 Carolina bays in the SRS Carolina Bay Restoration Project, permitted under NWP-27, "Wetland Restoration," was completed and closed in January.

- The TNX Water Pumphouse, 681-4T, on the Savannah River was removed and the bank stabilized under NWP-13, "Bank Stabilization." The project was completed and a permit closure notification was sent to the U.S. Army Corps of Engineers in October.

- The Pond B Dam Repair Project was permitted by letter from the U.S. Army Corps of Engineers in September 2003 under NWP-3, "Maintenance," so that the dam and the toe drain can be repaired. The work is scheduled to begin in 2004.

- The Mixed Waste Management Facility dam intake structure modification was applied for under NWP-38, "Hazardous Waste Cleanup."
The modification will improve the efficiency of the treatment system for tritium. Approval of this request is anticipated in early 2004.

\section{Construction in Navigable Waters}

SCDHEC Regulation 19-450, "Permit for Construction in Navigable Waters," protects the state's navigable waters through the permitting of any dredging, filling, construction, or alteration activity in, on, or over state navigable waters, in or on the beds of state navigable waters, or in or on land or waters subject to a public navigational servitude. The only state navigable waters at SRS are Upper Three Runs Creek (through the entire site) and Lower Three Runs Creek (upstream to the base of the PAR Pond Dam).

In 2003, SCDHEC issued an exemption letter for the removal and bank stabilization of the TNX Water Pumphouse, 681-4T.

\section{Federal Insecticide, Fungicide, and Rodenticide Act}

The Federal Insecticide, Fungicide, and Rodenticide Act restricts the application of restricted pesticides through a state-administered certification program. SRS complies with these requirements through procedural guidelines, and the site's pesticide procedure provides guidelines for pesticide use and requires that applicators of restricted-use pesticides be state certified.

\section{Clean Air Act}

\section{Regulation, Delegation, and Permits}

The Clean Air Act (CAA) provides the basis for protecting and maintaining air quality. Some types of SRS air emissions are regulated by EPA, but most are regulated by SCDHEC, which must ensure that its air pollution regulations are at least as stringent as the federal requirements. This is accomplished through SCDHEC Regulation 61-62, "Air Pollution Control Regulations and Standards."

Under the CAA, and as defined in federal regulations, SRS is classified as a "major source" and, as such, has been issued one operating permit for all of its sources of air pollutants. On February 19, 2003, SCDHEC's Bureau of Air Quality issued SRS its Title V Operating Permit (TV-0080-0041, which had an effective date of April 1, 2003, and an expiration date of March 31, 2008. As issued, the Title V Operating Permit regulates both radioactive and nonradioactive toxic and criteria pollutant emissions from approximately 98 emission units, with each emission unit having specific emission limits, operating conditions, and monitoring 
and reporting requirements. The permit also contains a listing, known as the Insignificant Activities List, of 1,329 SRS sources that are exempt based on insignificant emission levels, or equipment size or type. SRS also holds one construction permit for a new facility that is under construction.

During 2003, 14 of the permitted nonexempt emission units were taken out of service and voided on the Title V Permit. Of the other 84 nonexempt emission units, two were placed on the Insignificant Activities List, and 78 operated in some capacity during 2003. The remaining six were being maintained in "cold standby" status.

During 2003, SCDHEC conducted compliance inspections or stack tests of 175 permitted significant and insignificant sources at SRS, reviewing 317 permitted parameters.

\section{Notices of Violation (CAA)}

As a result of a failed biennial stack emissions test, SRS was issued an NOV, resulting in an overall site CAA compliance rate of 99.7 for 2003. The NOV, received by the site in May, was the result of an exceedance of the particulate matter emission limit observed during a biennial compliance stack test conducted at the A-Area No. 1 Boiler in February. Following receipt of the preliminary test report, immediate actions were taken to correct the cause of the high particulate matter emission rate, and a follow-up stack test was conducted in April, demonstrating compliance with the permit limit.

\section{National Emission Standards for Hazardous Air Pollutants}

The National Emission Standards for Hazardous Air Pollutants (NESHAP) is a CAA-implementing regulation that sets air quality standards for air emissions containing hazardous air pollutants, such as radionuclides, benzene, and asbestos. The current list of 189 air pollutants includes all radionuclides as a single item. Regulation of these pollutants has been delegated to SCDHEC; however, EPA Region IV continues to regulate some aspects of NESHAP radionuclides.

NESHAP Radionuclide Program Subpart H of 40 CFR 61 was issued December 15, 1989, after which an evaluation of all air emission sources was performed to determine compliance status. The Savannah River Operations Office (DOE-SR) and EPA Region IV signed a Federal Facility Compliance Agreement (FFCA) October 31, 1991, providing a schedule to bring SRS's emissions monitoring into compliance with regulatory requirements. The FFCA was officially closed — and the site declared compliant_-by EPA Region IV May 10, 1995. Subpart H was revised by EPA September 9, 2002, with an effective date of January 1, 2003. This revision added inspection requirements for existing SRS sources and allowed the use of ANSI N13.1-1999 for establishing monitoring requirements. SRS is performing all required inspections, has monitoring systems compliant with the regulation, and remains in compliance with Subpart $\mathrm{H}$ of 40 CFR 61.

During 2003, the maximally exposed individual effective dose equivalent, calculated using the NESHAP-required CAP88 computer code, was estimated to be $0.05 \mathrm{mrem}(0.0005 \mathrm{mSv})$, which is 0.5 percent of the 10 mrem per year $(0.10 \mathrm{mSv}$ per year $)$ EPA standard (chapter 5, "Potential Radiation Doses").

\section{NESHAP Nonradionuclide Program}

SRS uses many chemicals identified as toxic or hazardous air pollutants, but most of them are not regulated under the CAA or under federal NESHAP regulations. Except for asbestos, SRS facilities and operations do not fall into any of the "categories" listed in the subparts. Under Title III of the federal Clean Air Act Amendments (CAAA) of 1990, EPA in December 1993 issued a final list of hazardous air pollutant-emitting source categories potentially subject to maximum achievable control technology (MACT) standards.

As a result of EPA failing to meet the original rule development schedule, another CAA requirement, known as the 112 (j) MACT Hammer Permit Application, became effective 2 years after the missed scheduled date. This required the submittal of a two-part permit application by facilities considered "major" for hazardous air pollutants. Part I of the application, submitted to SCDHEC May 14, 2002, identified the MACT source categories that might be applicable to SRS and the facilities that could be impacted.

Part II of the application, originally due November 15, 2002, would have required each facility to identify the methods or control strategies it would use to reduce applicable pollutant emission levels. However, because of a December 2002 settlement agreement it reached with an environmental watch group, EPA has proposed a new schedule for promulgating the final rules for the remaining MACT source categories. This extends the development date into August 2005, with additional MACT Hammer provisions to take place 60 days after that date. The rules with potential impact to 
SRS facilities are to be promulgated by April 2004, with a compliance deadline 3 years later. In August 2003, EPA issued two of the MACT standards, "Site Remediation and Miscellaneous Metal Parts" and "Products Surface Coatings," which would potentially affect SRS facilities. As written, the Site Remediation MACT potentially would apply to the SRS soil vapor extraction and groundwater air stripper units; however, it includes an exemption for remediation units that are permitted under the RCRA and CERCLA corrective actions, which these SRS units are. With respect to the Miscellaneous Metal Parts and Products Surface Coatings MACT, it was anticipated originally that the SRS construction paint facility in N-Area would be subject to the requirements of this rule. However, because of the facility's limited use of surface coatings each year, SCDHEC has made an initial determination that the paint facility could qualify for the 250-gallon-per-year usage exemption.

In an attempt to regulate hazardous or toxic air pollutants in South Carolina, SCDHEC established Air Pollution Control Regulation 61-62.5, Standard No. 8, "Toxic Air Pollutants," in June 1991. To demonstrate compliance with this standard, SRS completed and submitted an air emissions inventory and air dispersion modeling data for all site sources in 1993. The submitted data demonstrated compliance by computer modeling the accumulated ambient concentration of individual toxic air pollutants at the boundary line and comparing them to the Standard No. 8 maximum allowable concentrations. To ensure continued compliance with Standard No. 8, new sources of toxic air pollutants must be permitted. This requires submittal of appropriate air permit applications and air dispersion modeling. Sources with emissions below a threshold of 1,000 pounds per month of any single toxic air pollutant may be exempted from permitting requirements. During 2003, 13 sources of toxic air pollutants either were issued a construction permit or exempted from permitting requirements.

\section{NESHAP Asbestos Abatement Program}

SRS began an asbestos abatement program in 1988 and continues to manage asbestos-containing material by "best management practices." Site compliance in asbestos abatement, as well as demolitions, falls under South Carolina and federal regulations, including SCDHEC Regulation R.61-86.1 ("Standards of Performance for Asbestos Projects") and 40 CFR 61, Subpart M ("National Emission Standards for Asbestos").

During 2003, SRS personnel removed and disposed of an estimated 306 square feet and 1,571 linear feet of regulated asbestos-containing material.
Radiological asbestos waste was disposed of at the SRS low-level burial ground, which is permitted by SCDHEC as an asbestos waste disposal site.

Nonradiological asbestos waste was disposed of at the Three Rivers Landfill, located on site, which also is an SCDHEC-approved asbestos waste landfill.

\section{Other CAA Requirements}

Only a few of the major sections of the CAA and its 1990 amendments and regulations have had, or are expected to have, a significant impact on SRS sources and facilities. These include Title V ("Permits") and Title VI ("Stratospheric Ozone Protection)." The other regulations affecting SRS facilities are implemented primarily in SCDHEC Regulation 61-62 and in existing operating or construction permits.

Title V Operating Permit Program As previously indicated, the CAAA of 1990 also include, under Title $\mathrm{V}$, a major new permitting section expected to have a significant impact on the site through increased reporting and recordkeeping requirements.

SRS and SCDHEC had been developing the Title V (Regulation 62.70, "Title V Operating Permit Program”) operating air permit since 1996, with several drafts of the permit being sent out for public comments. SCDHEC addressed the comments it received, and the SRS Title V permit was issued in February 2003, with an effective date of April 1, 2003.

Ozone Depleting Substances Title VI of the CAAA of 1990 addresses stratospheric ozone protection. This law requires that EPA establish a number of regulations to phase out the production and consumption of ozone-depleting substances (ODSs).

Several sections of Title VI of the CAAA of 1990, along with recently established EPA regulations found in 40 CFR 82, apply to the site. The ODSs are regulated in three general categories, as follows:

- Class I substances - chlorofluorocarbons (CFCs), Halons, carbon tetrachloride, methyl chloroform, methyl bromide, and hydrobromofluorocarbons (HBFCs)

- Class II substances - hydrochlorofluorocarbons (HCFCs)

\section{- $\quad$ Substitute substances}

The "Savannah River Site Refrigerant Management Plan," completed and issued in September 1994, provides guidance to assist SRS and DOE in the phaseout of CFC refrigerants and equipment.

SRS has reduced CFC refrigerant usage in large ODS emission sources more than 99 percent compared to 
1993 baseline data. The site used 450 pounds of CFC refrigerants in 2001, then reduced that amount to 180 pounds in 2002 and 50 pounds in 2003.

The SRS CAAA of 1990 Title V operating air permit application includes ODS emission sources. All large (greater than or equal to 50-pound charge) heating, ventilation, and air conditioning/chiller systems for which there are recordkeeping requirements are included as fugitive emission sources.

SRS is phasing out its use of Halon as a result of the DOE 1999 Pollution Prevention and Energy Efficient Leadership Goal to eliminate use of Class I ODSs by 2010 "to the extent economically practicable." A Halon 1301 alternative study was completed by the site's fire protection and systems engineering groups in 2000 to (1) recommend alternative fire suppression agents to replace Halon 1301 and (2) provide a method for assigning modification priorities to site fire protection systems that use Halon 1301.

Additionally, a Halon 1301 phaseout plan and schedule have been developed by Fire Protection Engineering to help meet DOE's goal. The plan includes an SRS Halon 1301 fire suppression system inventory that identifies systems in operation, systems abandoned in place, and systems that have been dismantled and taken to the DOE complex's Halon repository, located at SRS.

Halon 1301 total inventory on site decreased from 102,285 pounds in 2002 to 75,577 pounds in 2003. At the end of 2003, the site had an inventory of 51,737 pounds of stored Halon 1301, after having shipped approximately 15,000 pounds to the Defense Logistics Agency in Virginia. In addition, 22,040 pounds are contained in the 95 operating systems (down from 110 in 2002), and 1,800 pounds in the two systems that have been abandoned in place.

\section{Air Emissions Inventory}

SCDHEC Regulation 61-62.1, Section III ("Emissions Inventory"), requires compilation of an air emissions inventory for the purpose of locating all sources of air pollution and defining and characterizing the various types and amounts of pollutants. To demonstrate compliance, SRS personnel conducted the initial comprehensive air emissions inventory in 1993.

The inventory identified approximately 5,300 radiological and nonradiological air emission sources. Source operating data and calculated emissions from 1990 were used to establish the SRS baseline emissions and to provide data for air dispersion modeling. This modeling was required to demonstrate sitewide compliance with Regulation 61-62.5, Standard No. 2 ("Ambient Air Quality Standards"), and Standard No. 8 .

Regulation 61-62.1, Section III, requires that inventory data be updated and recorded annually but reported only every even calendar year. The emissions inventory is updated each year in accordance with SRS procedures and guidelines. Calendar year 2002 operating data for permitted and other significant sources were collected but not reported to SCDHEC in 2003. Because data collection for all SRS sources begins in January and requires up to 6 months to complete, this report provides emissions data for calendar year 2002. Compilation of 2003 data will be completed and submitted to SCDHEC in 2004 and reported in the SRS Environmental Report for 2004.

\section{Toxic Substances Control Act}

The Toxic Substances Control Act (TSCA) gives EPA comprehensive authority to identify and control chemical substances manufactured, imported, processed, used, or distributed in commerce in the United States. Reporting and record keeping are mandated for new chemicals and for any chemical that may present a substantial risk of injury to human health or the environment.

Polychlorinated biphenyls (PCBs) have been used in various SRS processes. The use, storage, and disposal of these organic chemicals are specifically regulated under 40 CFR 761, which is administered by EPA. SRS has a well-structured PCB program that complies with this TSCA regulation, with DOE orders, and with WSRC policies.

The site's 2003 PCB document log was completed in full compliance with 40 CFR 761 and submitted to EPA Region 4. The disposal of nonradioactive PCBs routinely generated at SRS is conducted at EPA-approved facilities within the regulatory period. For some forms of radioactive PCB wastes, disposal capacity is not yet available, and the wastes must remain in long-term storage. Such wastes are held in TSCA-compliant storage facilities in accordance with 40 CFR 761.

In 1993, PCBs were confirmed to be present as a component of dense nonaqueous phase liquids in samples from two groundwater monitoring wells around the M-Area Hazardous Waste Management Facility. Regulators were notified, and a modification to the RCRA Part B Permit Application to address the discovery of PCBs was submitted to SCDHEC. Soil and Groundwater Closure Projects and Savannah River Technology Center (SRTC) personnel continue 
to study ways to remediate the dense nonaqueous phase liquids.

In 1996 and subsequent years, site personnel discovered PCBs in certain painted surfaces and in other solid forms within several facilities constructed prior to TSCA. As such discoveries were made, SRS worked with EPA on related TSCA compliance issues. Current TSCA regulations prohibit the use and distribution in commerce of these forms of PCBs above specified concentrations. In December 1999, however, EPA issued a proposed rule to authorize the continued use of these forms of PCBs. EPA still has not issued a final rule.

\section{Endangered Species Act}

The Endangered Species Act of 1973, as amended, provides for the designation and protection of wildlife, fish, and plants in danger of becoming extinct. The act also protects and conserves the critical habitats on which such species depend.

Several threatened and endangered species exist at SRS. The site conducts research on the wood stork, the red-cockaded woodpecker, the bald eagle, the shortnose sturgeon, and the smooth purple coneflower. Programs designed to enhance the habitat of such species are in place.

No biological assessments and/or biological evaluations were prepared for NEPA documents for new projects at SRS in 2003. However, to ensure protection of threatened and endangered species, biological assessments and biological evaluations were conducted to evaluate potential impacts of forestry related activities. None of these activities was found to have had any significant potential impact on threatened and endangered species.

\section{National Historic Preservation Act}

The National Historic Preservation Act (NHPA) of 1966, Section 106, governs the protection and preservation of archaeological and historical resources. SRS ensures that it is in compliance with the NHPA through several processes. During 2003, extensive efforts were made through interactions with the South Carolina State Historical Preservation Office to identify SRS historic properties and to develop the SRS Cold War Programmatic Agreement (PA). Memoranda of agreement were used to deal, on an interim basis, with buildings included as part of the accelerated cleanup effort in several site areas, pending completion of the PA. A draft PA and a draft of the SRS Cultural Resources Management Plan were provided in November to the organizations belonging to the consulting parties, which include responsible state and federal agencies as well as area stakeholders interested in SRS.

In addition, the site helps ensure that it remains in compliance with NHPA through its Site Use Program. All sites being considered for activities such as construction are evaluated by University of South Carolina Savannah River Archaeological Research Program (SRARP) personnel to ensure that archaeological or historic sites are not impacted. Reviews of timber compartment prescriptions include surveying for archaeological resources and documenting areas of importance with regard to historic and prehistoric significance.

SRARP personnel reviewed 66 site-use packages and surveyed 405 acres during 2003. Most of the site-use packages were found to have no activities of significant impact in terms of the NHPA, but six of them resulted in surveys being conducted in 2003 because of the potential land for alteration. SRARP personnel also surveyed 1,530 acres in 2003 in support of onsite forestry activities. In addition, 304 acres of timber compartment clear-cuts were surveyed.

The surveys of the 2,239 total acres resulted in 84 site investigations of 63 new archaeological sites and in revisits to 21 previously recorded sites for cultural resources management.

\section{Floodplains and Wetlands}

Under 10 CFR, Part 1022 ("Compliance with Floodplains and Wetlands Environmental Review Requirements") DOE establishes policies and procedures for implementing its responsibilities in terms of compliance with Executive Orders 11988 ("Floodplain Management") and 11990 ("Protection of Wetlands"). Part 1022 includes DOE policies regarding the consideration of floodplains/wetlands factors in planning and decision making. It also includes DOE procedures for identifying proposed actions involving floodplains/wetlands, providing early public reviews of such proposed actions, preparing floodplains/ wetlands assessments, and issuing statements of findings for actions in floodplains. No floodplain or wetlands assessments were conducted in 2003.

\section{Executive Order 11988}

Executive Order 11988 ("Floodplain Management") was established to avoid long- and short-term impacts associated with the occupancy and modification of floodplains. The evaluation of impacts to SRS floodplains is ensured through the NEPA Evaluation Checklist and the site-use system. Site-use applications are reviewed for potential impacts by WSRC, DOE-SR, the USDA Forest Service-Savannah River 
and the Savannah River Ecology Laboratory (SREL), as well as by professionals from other organizations.

\section{Executive Order 11990}

Executive Order 11990 ("Protection of Wetlands") was established to mitigate adverse impacts to wetlands caused by the destruction and modification of wetlands and to avoid new construction in wetlands wherever possible. Avoidance of impact to SRS wetlands is ensured through the site-use process, various departmental procedures and checklists, and project reviews by the SRS Wetlands Task Group. Many groups and individual-including scientists from SRTC, SREL, and the Environmental Services Section-review site-use applications to ensure that proposed projects do not impact wetlands.

\section{Environmental Release Response and Reporting}

\section{Response to Unplanned Releases}

Environmental Monitoring and Analysis (EMA) personnel respond to unplanned environmental releases, both radiological and nonradiological, upon request by area operations personnel. No unplanned environmental releases occurred at SRS in 2003 that required the sampling and analysis services of EMA.

\section{Occurrences Reported to Regulatory Agencies}

Federally permitted releases comply with legally enforceable licenses, permits, regulations, or orders. If a nonpermitted release to the environment of a reportable quantity or more of a hazardous substance (including radionuclides) occurs, CERCLA requires notification of the National Response Center. Also, the CWA requires that the National Response Center be notified if an oil spill causes a "sheen" on navigable waters, such as rivers, lakes, or streams. Oil spill reporting was reinforced with liability provisions in the CERCLA National Contingency Plan.

SRS had no CERCLA-reportable releases in 2003. This performance compares with zero releases reported during 2000, 2001, and 2002; one release in 1999; and one in 1998.

Two notifications, not required by CERCLA, were made by the site to regulatory agencies during 2003. Both were the result of an agreement to notify SCDHEC about sewage and petroleum product releases.
EPCRA (40 CFR 355.40) requires that reportable releases of extremely hazardous substances or CERCLA hazardous substances be reported to any local emergency planning committees and state emergency response commissions likely to be affected by the release. No EPCRA-reportable releases occurred in 2003.

\section{Site Item Reportability and Issues Management Program}

The Site Item Reportability and Issues Management (SIRIM) program, mandated by DOE Order 232.1A ("Occurrence Reporting and Processing of Operations Information") is designed to ". . . establish a system for reporting of operations information related to DOE-owned or operated facilities and processing of that information to provide for appropriate corrective action. . . ." It is the intent of the order that DOE be ". . . kept fully and currently informed of all events which could (1) affect the health and safety of the public; (2) seriously impact the intended purpose of DOE facilities; (3) have a noticeable adverse effect on the environment; or (4) endanger the health and safety of workers."

Of the 233 SIRIM-reportable events in 2003, the following three events were categorized as environmental:

- $\quad$ Sanitary wastewater was found to be leaking from a manhole cover east of building 714-7N. The leak was estimated to be greater than 500 gallons and was determined to have been caused by movement and damage to the manhole concrete collar. The release was contained and remediated without the wastewater entering waters of the state.

- South Carolina Electric and Gas personnel were cutting trees along a site electrical transmission line right-of-way when a tree fell across an 8-inch main sanitary sewage pipe operated by the WSRC Solid Waste and Infrastructure Site Utilities Department. The pipe ruptured, resulting in a sewage spill that reached Fourmile Branch (waters of the state); the estimated volume of the resulting spill was 13,788 gallons. Actions were taken to minimize flow to the damaged pipe. Pumps upstream of the pipe were shut down and valves downstream of the break were closed. A vendor transferred sewage from the upstream pump station to minimize the release.

- The site reported the NOV received from SCDHEC for failure of the A-Area boiler to pass a compliance test. The failure was the result inadequate post-maintenance testing of multiclone dust collectors. 


\section{Assessments/Inspections}

The SRS environmental program is overseen by a number of organizations, both outside and within the DOE complex. In 2003, the WSRC environmental appraisal program consisted of self and independent assessments. The program ensures the recognition of noteworthy practices, the identification of performance deficiencies, and the initiation and tracking of associated corrective actions until they are satisfactorily completed. The primary objectives of the WSRC assessment program are to ensure compliance with regulatory requirements and to foster continuous improvement. The program is an integral part of the site's Safety Management System and supports the SRS Environmental Management System, which continues to meet the standards of International Organization for Standardization (ISO) 14001. (ISO 14000 is a family of voluntary environmental management standards and guidelines.)

WSRC conducted nine environmental program-level assessments in 2003. The topics included

- Domestic Water Quality - Facility Operations and Maintenance

- Surface Water Quality - Operator and Laboratory Certification

- Environmental Radiation Protection Environmental Radiological Surveillance

- Air Quality Protection - Facility Permits

- Toxic and Chemical Materials - Polychlorinated Biphenyls (PCBs)

- Toxic and Chemical Materials - Spill Prevention and Management

- Environmental Management Functions Environmental Protection Program

- Environmental Management Functions - Program Evaluation, Corrective Action, and Continuous Improvement

- Groundwater Protection

During 2003, personnel from DOE-SR's Environmental Quality and Management Division continued to perform direct oversight and evaluation of WSRC's self-assessment program. Completed DOE assessments have met with positive results; routine assessments have promoted improvement and helped ensure the adequacy of environmental programs and operations at SRS.

SCDHEC and EPA personnel also performed external inspections of the SRS environmental program for regulatory compliance. Agency representatives performed several comprehensive compliance inspections in 2003, as follows:

- RCRA Compliance Evaluation Inspection - The annual compliance evaluation inspection is an unannounced audit by SCDHEC and/or EPA. SCDHEC conducted the 2003 inspection for compliance with solid and hazardous waste management regulations. No deficiencies were noted during the entire audit.

- Annual Air Compliance Inspection - SCDHEC conducted the annual air compliance inspection of operating SRS permitted sources. In general, the site was found to be in compliance with each source's respective permit condition and requirement.

- Annual Underground Storage Tank Inspection SCDHEC inspected the site's 19 underground storage tanks. All were found to be in compliance with applicable regulations.

- Annual NPDES 3560 Compliance Audit SCDHEC conducted the annual 3560 environmental audit of the site's NPDES-permitted outfalls. Overall, SRS received a rating of noncompliance from the regulators. The noncompliance rating stemmed from flow measurement discrepancies at one outfall, which resulted in that portion of the assessment being graded as unsatisfactory. Additionally, marginal ratings were received in the areas of operations and maintenance and stormwater. The issues raised in the inspection report have been addressed by site personnel, and corrective actions have been implemented.

- Quarterly Inspections of SRS Bottled Water Facility - SCDHEC conducted quarterly inspections of the SRS Bottled Water Facility. Overall, the results of these inspections were favorable.

- SRS Domestic Water Laboratory Certification Audit-SCDHEC conducted an evaluation of SRS's Domestic Water Laboratory for the purpose of renewing the 3-year certificate the laboratory holds to perform coliform analyses that are routinely reported to SCDHEC for compliance purposes. The certificate was reissued.

- Burma Road C\&D Landfill, Burma Road Structural Fill, 632-G C\&D Landfill, and Saltstone Inspection - SCDHEC conducted quarterly inspections, and all the sites were found to be satisfactory, with no observed deficiencies.

- Interim Sanitary Landfill - SCDHEC personnel conducted an annual post-closure inspection, and 
the site was found to be satisfactory, with no observed deficiencies.

- Groundwater Comprehensive Monitoring Evaluation - SCDHEC conducted an unannounced RCRA inspection of SRS's groundwater program. No deficiencies or permit violations were cited.

\section{Environmental Training}

The site's environmental training program identifies training activities to teach job-specific skills that protect the employee and the environment, in addition to satisfying regulatory training requirements. Regularly scheduled classes in this program at SRS include such topics as Environmental Laws and Regulations, Low-Level Waste Certification, Pollution Prevention and Waste Minimization, and the Environmental Compliance Authority course. More than 40 environmental program-related training courses are listed in the site training database, and individual organizations schedule and perform other facility-specific, environment-related training to ensure that operations and maintenance personnel, as well as environmental professionals, have the knowledge and skills to perform work safely and in a manner that protects the environment.

\section{Site Decommissioning and Demolition}

Site D\&D (decommissioning and demolition), formerly Facility Disposition Projects, assumed responsibility in 2003 for all decommissioning and demolition work at SRS. Personnel from Site D\&Dalso known as $\mathrm{CH} 2 \mathrm{SRC}$, a subsidiary of $\mathrm{CH} 2 \mathrm{M}$ Hill- will continue to work toward reduction of the site "footprint." By the end of 2003, the organization had participated in the following accomplishments/ activities:

- Fifty buildings had been demolished across the site.

- The 10th F-Area building was under demolition.

- Twenty-six of 28 buildings had been demolished in T-Area.

- The last "six-pack" building in M-Area was under demolition.

- Eleven buildings had been demolished in D-Area.

- Deactivation had begun in the site's main cafeteria building.

- Crews continued to deactivate Naval Fuels building areas ("zones") ahead of schedule.

\section{Environmental Permits}

SRS had 412 construction and operating permits in 2003 that specified operating levels for each permitted source. Table 2-4 summarizes the permits held by the site during the past 5 years. These numbers reflect only permits obtained by WSRC for itself and for other SRS contractors that requested assistance in obtaining permits. It also should be noted that these numbers include some permits that were voided or closed some time during the calendar year (2003). The continued reduction in the number of environmental permits reflects site efforts to (1) close permits as facilities are deactivated or decommissioned and (2) consolidate and streamline facility permits to help improve operating and administrative efficiency. 
Table 2-4 SRS Construction and Operating Permits, 1999-2003

\begin{tabular}{lrrrrr}
\hline Type of Permit & \multicolumn{5}{c}{ Number of Permits } \\
\hline & 1999 & 2000 & 2001 & 2002 & 2003 \\
Air & 200 & 199 & 172 & 150 & $2^{\mathrm{b}}$ \\
U.S. Army Corps of Engineers 404 & 0 & 0 & 0 & 0 & 0 \\
Army Corps of Engineers Nationwide Permit & 4 & 1 & 5 & 5 & 5 \\
Domestic Water & 203 & 203 & 203 & 203 & 202 \\
Industrial Wastewater & 86 & 77 & 70 & 66 & 60 \\
NPDES Discharge & 1 & 1 & 1 & 1 & 1 \\
NPDES General Utility & 1 & 1 & 0 & 0 & 0 \\
NPDES No Discharge & 1 & 1 & 1 & 1 & 1 \\
NPDES Stormwater & 2 & 2 & 2 & 2 & 2 \\
RCRA & 1 & 1 & 1 & 1 & 1 \\
Sanitary Wastewater & 141 & 133 & 133 & 133 & 109 \\
SCDHEC 401 & 1 & 1 & 1 & 0 & 0 \\
SCDHEC Navigable Waters & 0 & 0 & 1 & 1 & 0 \\
Solid Waste & 5 & 5 & 4 & 2 & 3 \\
Underground Injection Control & 18 & 23 & 20 & 18 & 19 \\
Underground Storage Tanks & 20 & $7^{\mathrm{a}}$ & 7 & 7 & 7 \\
\cline { 2 - 6 } Totals & 684 & 655 & 621 & 590 & 412
\end{tabular}

a This number was revised to reflect the actual number of permits that included requirements for 19 underground storage tanks.

b This number was revised to reflect the Title V Operating Permit, which includes all SRS air emission sources and one construction permit.

Editor's note: The "Environmental Compliance" chapter is unique in that the number of contributing authors is far greater than the number for any other chapter in this report. Space/layout constraints prevent us from listing all of them on the chapter's first page, so we list them here instead. Their contributions, along with those of the report's other authors, continue to play a critical role in helping us produce a quality documentand are very much appreciated.

\begin{tabular}{lll}
\hline Ronald Beul, CBU & Linda Karapatakis, FSSBU & Hal Morris, OBU \\
Paul Carroll, FSSBU & Bruce Lawrence, OBU & Vernon Osteen, FSSBU \\
Carl Cook, FSSBU & Linn Liles, FSSBU & Donald Padgett, FSSBU \\
Natalie Ferguson, OBU & Jeff Lintern, FSSBU & Paul Rowan, OBU \\
Pete Fledderman, FSSBU & Nancy Lowry, FSSBU & Stuart Stinson, FSSBU \\
Chuck Hayes, CBU & Bart Marcy, FSSBU & \\
\hline
\end{tabular}





\section{Chapter 3}

\section{Effluent Monitoring}

\section{Carl Cook, Pete Fledderman, Donald Padgett, and Monte Steedley \\ Environmental Services Section}

Timothy Jannik

Savannah River Technology Center

$\mathrm{E}$ FFLUENT monitoring at Savannah River Site (SRS) is conducted to demonstrate compliance with applicable standards and regulations. Site effluent monitoring activities are divided into radiological and nonradiological programs. A complete description of sampling and analytical procedures used for effluent monitoring by the Environmental Monitoring and Analysis group of the site's Environmental Services Section can be found in sections 1101-1111 (SRS EM Program) of the Savannah River Site Environmental Monitoring Section Plans and Procedures, WSRC-3Q1-2, Volume 1. A summary of data results is presented in this chapter; more complete data can be found in tables on the CD included with this report.

\section{Radiological Monitoring}

Radiological effluent monitoring results are a major component in determining compliance with applicable dose standards. SRS management philosophy ensures that potential exposures to members of the public and to onsite workers are kept as far below regulatory standards as is reasonably achievable. This philosophy is known as the "as low as reasonably achievable" (ALARA) concept.

SRS airborne and liquid effluents that potentially contain radionuclides are monitored at their points of discharge by a combination of direct measurement and/or sample extraction and analysis. Each operating facility maintains ownership of and is responsible for its radiological effluents.

Unspecified alpha and beta emissions (the measured gross activity minus the identified individual radionuclides) in airborne and liquid releases are large contributors - on a percentage basis - to offsite doses, especially for the airborne pathway from diffuse and fugitive releases. Because some (if not most) of these emissions are from naturally occurring radionuclides, these emissions are accounted for separately from actual strontium-90 and plutonium-239 emissions. Therefore, releases of unspecified alpha and beta emissions are listed separately in the source term.
Prior to 2000, these emissions were included in plutonium-239 and strontium-89,90 releases. For dose calculations, the unspecified alpha releases were assigned the plutonium-239 dose factor, and the unspecified beta releases were assigned the strontium90 dose factor (chapter 5, "Potential Radiation Doses").

\section{Airborne Emissions}

Process area stacks that release or have the potential to release radioactive materials are monitored continuously by applicable online monitoring and/or sampling systems [SRS EM Program, 2001].

Depending on the processes involved, discharge stacks also may be monitored with "real-time" instrumentation to determine instantaneous and cumulative atmospheric releases to the environment. Tritium is one of the radionuclides monitored with continuous real-time instrumentation.

The following effluent sampling and monitoring changes were made during 2003:

- $\quad$ Samples from H and F Area Tank Farms no longer are composited. SRS received approval (for most Tank Farm locations) to pull samples from individual locations annually or semiannually instead of weekly. Samples still are collected weekly from the high-level waste evaporator and from 299-H.

- $\quad$ Samples from the main stacks of the C-Area, KArea, and L-Area Reactors and the L-Area Disassembly Basin now are collected quarterly.

- Samples from the 105-C decon exhaust, 105-C crane maintenance exhaust, and the 772-1F, 772$4 \mathrm{~F}$, and 235-F sandfilter now are collected semiannually.

- Samples now are collected annually from the 511-S low-point pit and all 250-S glass-waste storage buildings, and quarterly from $221-S$, zone 2 . 


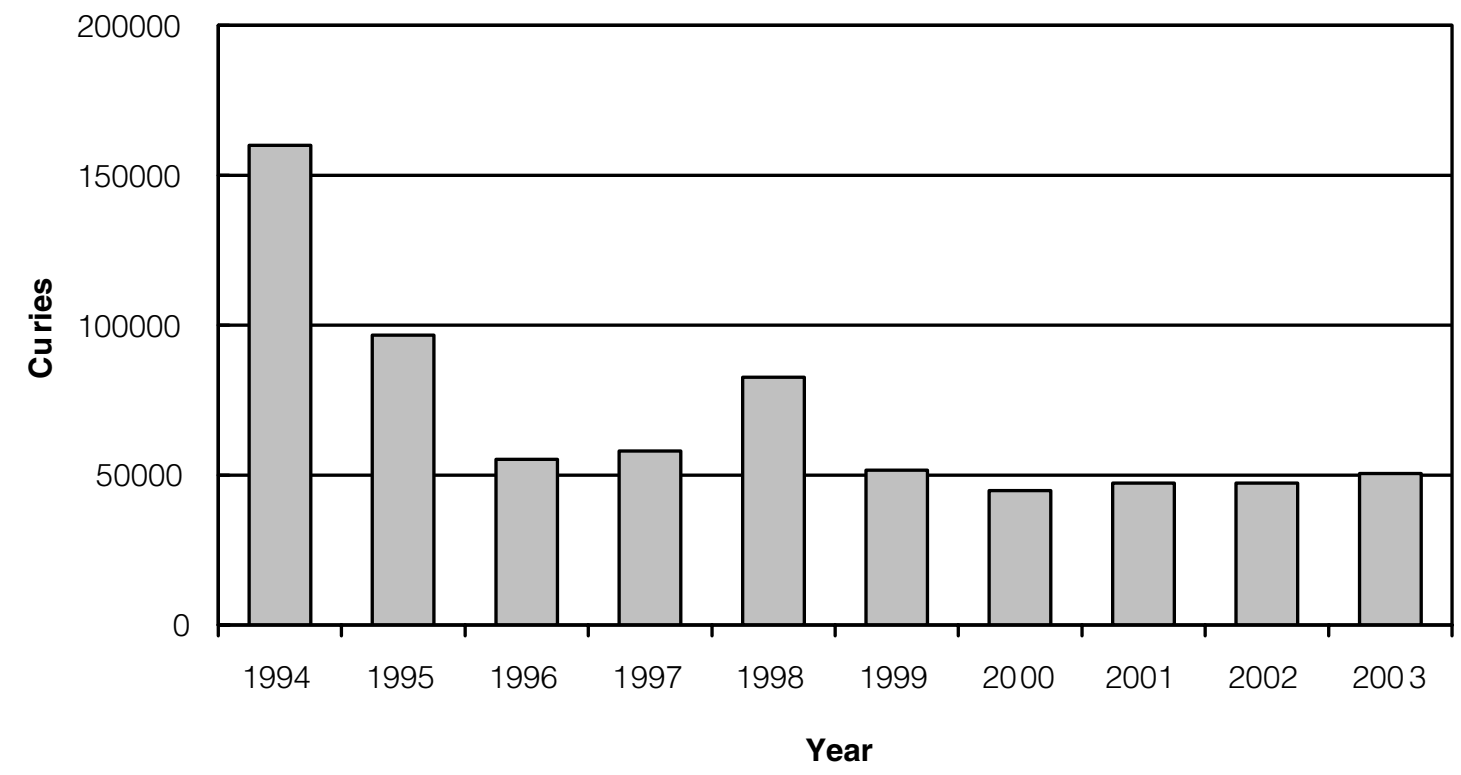

Figure 3-1 Ten-Year History of SRS Annual Atmospheric Tritium Releases

- Sample collection has been discontinued at ALine stack, 800 cell exhaust stack, 6.1D, and 6.4D. Sampling at these locations will not resume unless the facilities associated with the release points are operating.

\section{Diffuse and Fugitive Sources}

Estimates of radionuclide releases from unmonitored diffuse and fugitive sources also are included in the SRS radioactive release totals. A diffuse source is defined as an area source. A fugitive source is defined as an undesigned localized source.

Diffuse and fugitive releases are calculated using the U.S. Environmental Protection Agency's (EPA's) recommended methods. Because these methods are conservative, they generally lead to overestimates of actual emissions.

\section{Monitoring Results}

The total amount of radioactive material released to the environment is quantified by using data obtained from continuously monitored airborne effluent releases points and estimates of diffuse and fugitive sources in conjunction with calculated release estimates of unmonitored radionuclides from the separations areas.

The unmonitored radionuclides in the separations areas are fission product tritium, carbon-14, and krypton-85. These radionuclides cannot be measured readily in the effluent streams; therefore, the values are calculated on an annual basis and are based on production levels.

Because of increased operations in H-Canyon, the amount of krypton-85 estimated to have been released by the site increased from $31,500 \mathrm{Ci}$ in 2002 to 63,000 in 2003. Krypton-85 accounted for about 56 percent of the total radioactivity released to the atmosphere from SRS operations.

Tritium Tritium in elemental and oxide forms accounted for 44 percent of the total radioactivity released to the atmosphere from SRS operations. During 2003, about 50,000 Ci of tritium were released from SRS, compared to about 47,300 Ci in 2002.

Because of improvements in facilities, processes, and operations, and because of changes in the site's missions, the amount of tritium (and other atmospheric radionuclides) released generally has declined during the past 15 years at SRS. In recent years, because of changes in the site's missions and the existence of the Replacement Tritium Facility, the total amount of tritium released has fluctuated but has remained less than 100,000 Ci per year (figure 3-1).

Comparison of Average Concentrations in Airborne Emissions to DOE Derived Concentration

Guides Average concentrations of radionuclides in airborne emissions are calculated by dividing the yearly release total of each radionuclide from each stack by the yearly stack flow quantities. These average concentrations then can be compared to the DOE derived concentration guides (DCGs) in DOE 
Order 5400.5, "Radiation Protection of the Public and the Environment," as a screening method to determine if existing effluent treatment systems are proper and effective. The 2003 atmospheric effluent annualaverage concentrations, their comparisons against the DOE DCGs, and the quantities of radionuclides released are provided, by discharge point, on the $\mathrm{CD}$ accompanying this report.

DCGs are used as reference concentrations for conducting environmental protection programs at all DOE sites. DCGs are applicable at the point of discharge (prior to dilution or dispersion) under conditions of continuous exposure.

Most of the SRS radiological stacks/facilities release small quantities of radionuclides at concentrations below the DOE DCGs. However, certain radionuclides - tritium (in the oxide form) from the reactor facilities and the tritium facilities, plutonium-239 and uranium-238 from the 291-F stack, cesium-137 from the 241-F miscellaneous exhaust, 241-H miscellaneous exhaust and 244-H vessel vent and americium-241 from the 800 cell stack-were emitted at concentration levels above the DCGs. Because of the extreme difficulty involved in removing tritium and because of current facility designs, site missions, and operational considerations, this situation is unavoidable. The offsite dose consequences from all atmospheric releases during 2003, however, remained well below the DOE and EPA annual atmospheric pathway dose standard of 10 mrem $(0.1 \mathrm{mSv})$ (chapter 5).

\section{Liquid Discharges}

Each process area liquid effluent discharge point that releases or has potential to release radioactive materials is sampled routinely and analyzed for radioactivity [SRS EM Program, 2001].

Depending on the processes involved, liquid effluents also may be monitored with real-time instrumentation to ensure that instantaneous releases stay within established limits. Because the instruments have limited detection sensitivity, online monitoring systems are not used to quantify SRS liquid radioactive releases at their current low levels.

\section{Monitoring Results}

Data from continuously monitored liquid effluent discharge points are used in conjunction with site seepage basin and Solid Waste Disposal Facility migration release estimates to quantify the total radioactive material released to the Savannah River from SRS operations. SRS liquid radioactive releases for 2003 are shown by source on the CD accompany- ing this report. These data are a major component in the determination of offsite dose consequences from SRS operations.

Direct Discharges of Liquid Effluents Direct discharges of liquid effluents are quantified at the point of release to the receiving stream, prior to dilution by the stream. The release totals are based on measured concentrations and flow rates.

Tritium accounts for nearly all the radioactivity discharged in SRS liquid effluents. The total amount of tritium released directly from process areas (i.e., reactor, separations, Effluent Treatment Facility) to site streams during 2003 was 1,553 Ci, which was 36 percent more than the 2002 total of $1,140 \mathrm{Ci}$.

Direct releases of tritium to site streams for the years 1994-2003 are shown in figure 3-2. The migration and transport of radionuclides from site seepage basins and the Solid Waste Disposal Facility is discussed in chapter 4 ("Environmental Surveillance").

\section{Comparison of Average Concentrations in Liquid Releases to DOE Derived Concentration Guides} In addition to dose standards, DOE Order 5400.5 imposes other control considerations on liquid releases. These considerations are applicable to direct discharges but not to seepage basin and Solid Waste Disposal Facility migration discharges. The DOE order lists DCG values for most radionuclides.

DCGs are applicable at the point of discharge from the effluent conduit to the environment (prior to dilution or dispersion). According to DOE Order 5400.5, exceedance of the DCGs at any discharge point may require an investigation of "best available technology" waste treatment for the liquid effluents. Tritium in liquid effluents is specifically excluded from "best available technology" requirements; however, it is not excluded from other ALARA considerations. DOE DCG compliance is demonstrated when the sum of the fractional DCG values for all radionuclides detectable in the effluent is less than 1.00, based on consecutive 12-month-average concentrations. The 2003 liquid effluent annual-average concentrations, their comparisons against the DOE DCGs, and the quantities of radionuclides released are provided, by discharge point, on the $\mathrm{CD}$ accompanying this report.

The data show that the U3R-2A ETF outfall at the Road C discharge point exceeded the DCG guide for 12-month-average tritium concentrations during 2003. However, as noted previously, DOE Order 5400.5 specifically exempts tritium from "best available technology" waste treatment investigation requirements. This is because there is no practical technology 


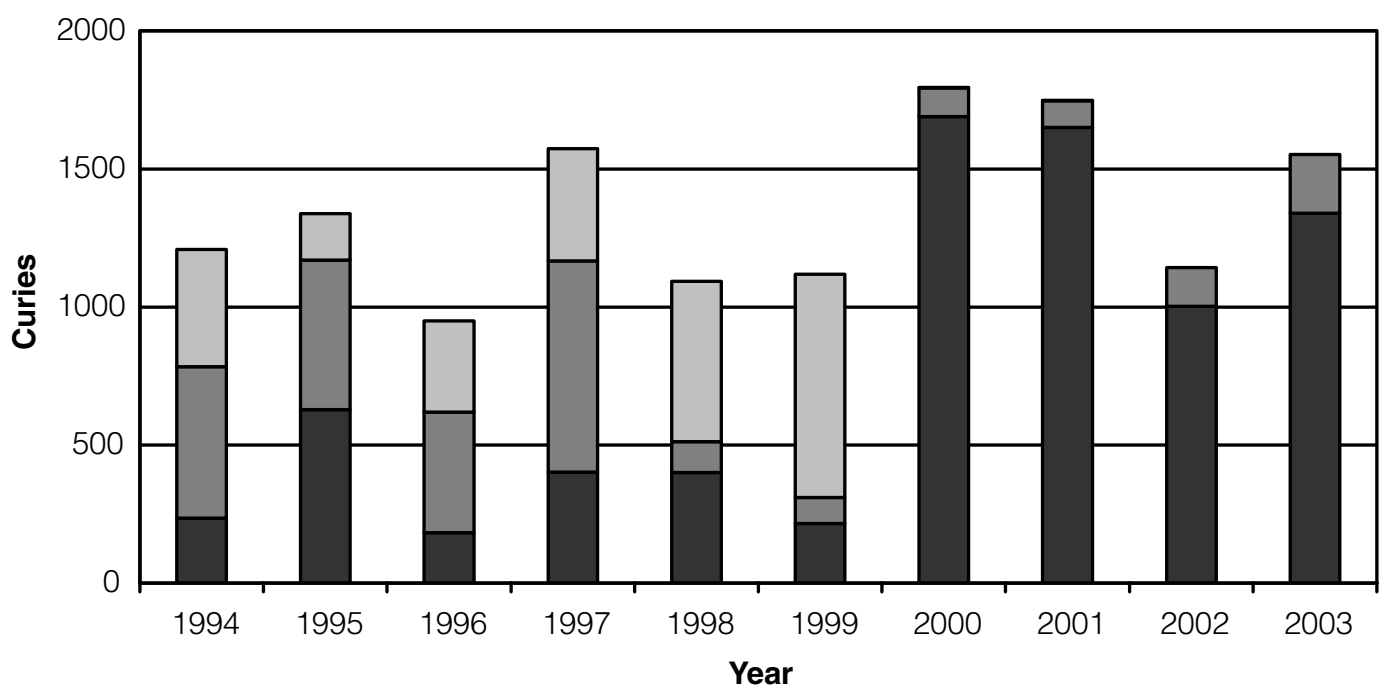

$\square$ Separations Areas $\square$ Reactor Areas $\square$ D-Area, TNX, A-Area

Figure 3-2 Ten-Year History of Direct Releases of Tritium to SRS Streams

Operations at D-Area and TNX were discontinued in 2000 and 2001, respectively. Releases from A-Area and the reactor areas represent only a small percentage of the total direct releases of tritium to site streams. The reactor area releases include the overflows from PAR Pond and L Lake.

available for removing tritium from dilute liquid waste streams. No other discharge points exceeded the DOE DCGs during 2003.

\section{Nonradiological Monitoring}

\section{Airborne Emissions}

The South Carolina Department of Health and Environmental Control (SCDHEC) regulates both radioactive and nonradioactive criteria and toxic air pollutant emissions - from SRS sources. Each source of air emissions is permitted or exempted by SCDHEC on the new SRS Title V Operating Permit, with specific limitations and monitoring requirements identified. This section will cover only nonradioactive emissions.

The bases for the limitations and monitoring requirements specified in the Title V Operating Permit are outlined in various South Carolina and federal air pollution control regulations and standards. Many of the applicable standards are source dependent, i.e., applicable to certain types of industry, processes, or equipment. However, some standards govern all sources for criteria and toxic air pollutants and ambient air quality. Air pollution control regulations and standards applicable to SRS sources are discussed briefly in appendix A, "Applicable Guidelines, Standards, and Regulations." The SCDHEC air standards for toxic air pollutants can be found at http:// www.scdhec.net/baq on the Internet.

At SRS, 84 nonexempt permitted radiological and nonradiological air emission units are identified in the new Title V Operating Permit, 78 of which were in operation in some capacity during 2003. The remaining six sources either were being maintained in a "cold standby" status or were under construction.

\section{Description of Monitoring Program}

Major nonradiological emissions of concern from stacks at SRS facilities include sulfur dioxide, carbon monoxide, oxides of nitrogen, particulate matter smaller than 10 microns, volatile organic compounds (VOCs), and toxic air pollutants. With the issuance of the new Title V Operating Permit, SRS has several new continuous and periodic monitoring requirements; only the most significant are discussed below.

The primary method of source monitoring at SRS, is the annual air emissions inventory. Emissions from SRS sources are determined during this inventory from standard calculations using source operating parameters, such as hours of operation, process throughput, and emission factors provided in the EPA "Compilation of Air Pollution Emission Factors," AP42. Many of the processes at SRS, however, are unique sources requiring nonstandard, complex 
calculations. The hourly and total annual emissions for each source then can be compared against their respective permit limitations.

At the SRS powerhouses, airborne emission specialists under contract to SRS perform stack compliance tests every 2 years for each boiler. The tests include sampling of the boiler exhaust gases to determine particulate matter emissions and laboratory analysis of coal for sulfur content and British thermal unit (Btu) output for calculating sulfur dioxide emissions. Also, as required by the Title $\mathrm{V}$ Permit, a visible emissions inspection is conducted daily to verify compliance with opacity standards.

For the package steam generating boilers in K-Area, fuel oil-fired water heaters in B-Area, and dieselpowered equipment, compliance with sulfur dioxide standards is determined by analysis of the fuel oil purchased from the offsite vendor. The percent of sulfur in the fuel oil must be below 0.5 and, as required by the Title V Permit, must be reported to SCDHEC annually as part of the SRS annual compliance certification report due in April 2004.

Monitoring of SRS diesel-powered equipment consists of tracking fuel oil consumption monthly and calculating a 12-month rolling total for determining permit compliance with a site consumption limit.

SRS has several sources of toxic air pollutants; however, there are no specific monitoring requirements in their respective permits. Because some toxic air pollutants also are regulated as VOCs, some SRS sources (soil vapor extraction units and air strippers) are required to be monitored by calculating and reporting VOC emissions on a quarterly basis.

Compliance by all SRS permitted sources is determined during annual compliance inspections by the local SCDHEC district air manager. The inspections consist of a review of each permit condition, i.e., daily monitoring readings, equipment calibrations, control device inspections, etc.

Compliance by all toxic air pollutant and criteria pollutant sources also is determined by using U.S. Environmental Protection Agency (EPA)-approved air dispersion models. The Industrial Source Complex Version No. 3 model was used to predict maximum ground-level concentrations occurring at or beyond the site boundary for new sources permitted in 2003.

\section{Monitoring Results}

In 2003, operating data were compiled and emissions calculated for 2002 operations for all site air emission sources. Because this process, which begins in January, requires up to 6 months to complete, this report will provide a comprehensive examination of total 2002 emissions, with only limited discussion of available 2003 monitoring results for specific sources.

The 2002 total criteria and toxic air pollutant emissions results for all SRS sources, as determined by the 2003 air emissions inventory, are provided in table 3-1 and on the CD accompanying this report. A review of the calculated emissions for each source for calendar year 2002 determined that SRS sources had operated in compliance with permitted emission rates. Actual 2003 emissions will be compiled and reported in depth in the SRS Environmental Report for 2004. Some toxic air pollutants (e.g., benzene) regulated by SCDHEC also are, by nature, VOCs. As such, the total for VOCs in table 3-1 includes toxic air pollutant emissions. This table also includes the emissions for some hazardous air pollutants that are regulated under the Clean Air Act but not by SCDHEC Standard No. 8 . These pollutants are included because they are compounds of some Standard No. 8 pollutants.

Two power plants with five overfeed stoker-fed coalfired boilers are operated by Westinghouse Savannah River Company (WSRC) at SRS. The location, number of boilers, and capacity of each boiler for these plants are listed in table 3-2. Because of an alternating test schedule, only A-Area boiler No. 1 was stack tested in 2003 (February). At that time, the boiler's particulate matter emissions were found to be in excess of its permitted limit-for which SRS was issued a notice of violation by SCDHEC. The cause of the excess emissions was corrected, and the boiler was retested in April. Results from the followup test, shown in table 3-3, indicated the boiler was operating in compliance with permitted emission rates.

\section{Table 3-1}

2002 Criteria Pollutant Air Emissions

Pollutant Name
Actual Emissions
(Tons/Year)

Sulfur dioxide

Total suspended particulates

$5.58 \mathrm{E}+02$

$\mathrm{PM}_{10}$ (particulate matter 10 microns)

Carbon monoxide

Ozone (volatile organic compounds)

$2.15 \mathrm{E}+02$

$9.86 \mathrm{E}+01$

$1.22 \mathrm{E}+03$

$7.99 \mathrm{E}+01$

Gaseous fluorides (as hydrogen fluoride)

Nitrogen dioxide

1.26E-01

$3.06 \mathrm{E}+02$

Lead

$3.47 \mathrm{E}-01$

a From all SRS sources (permitted and nonpermitted) 
Table 3-2

SRS Power Plant Boiler Capacities

\begin{tabular}{lcr}
\hline Location & $\begin{array}{l}\text { Number of } \\
\text { Boilers }\end{array}$ & $\begin{array}{r}\text { Capacity } \\
\text { (Btu/hr) }\end{array}$ \\
A-Area & 2 & $71.7 \mathrm{E}+06$ \\
H-Area & 3 & $71.1 \mathrm{E}+06$
\end{tabular}

SRS also has two package steam generating boilers in K-Area fired by No. 2 fuel oil. As required by the previous operating permit, the percent of sulfur in the fuel oil burned during the first quarter of 2003 was certified by the vendor to meet the requirements of the permit. This now is an annual SCDHEC reporting requirement.

At SRS, 125 permitted and exempted sources, both portable and stationary, are powered by internal combustion diesel engines. These sources include portable air compressors, diesel generators, emergency cooling water pumps, and fire water pumps. As required by the Title V Permit, fuel oil consumption was tracked monthly, and the 12-month rolling total consumption for 2003 was found to be well below the SRS limit for the entire reporting period.

Twenty-one of the SRS sources are permitted for toxic air pollutants; 14 of these were operated during 2003. Several of the toxic air pollutant sources-specifically, the soil vapor extraction and air stripper units-have permit conditions requiring the calculation of the 12month running total annual VOC emissions, which are to be calculated and reported to SCDHEC quarterly. As reported to SCDHEC during 2003, the calculated annual VOC emissions were determined to be well below the permit limit for each unit.

Though it is not identified on the SRS permit, another significant source of criteria pollutant emissions is the controlled burning of vegetation and undergrowth by the U.S. Department of Agriculture Forest ServiceSavannah River (USFS-SR) as a means of preventing uncontrolled forest fires. The emissions from the

Table 3-3

Boiler Stack Test Results (A-Area)

\begin{tabular}{|c|c|c|c|c|}
\hline \multicolumn{2}{|c|}{ Boiler } & \multirow[t]{2}{*}{ Pollutant } & \multicolumn{2}{|c|}{ Emission Rates } \\
\hline & & & $\mathrm{lb} / 10^{6} \mathrm{Btu}$ & $\mathrm{lb} / \mathrm{hr}$ \\
\hline \multicolumn{2}{|l|}{ A \#1 } & Particulates $^{a}$ & 0.299 & 23.97 \\
\hline $\begin{array}{l}\mathrm{T} \\
\mathrm{a}\end{array}$ & \multicolumn{4}{|c|}{$\begin{array}{l}\text { The compliance level is } 0.6 \mathrm{lb} / \text { million Btu for particulates } \\
\text { and } 3.5 \mathrm{lb} / \text { million Btu for sulfur dioxide }\end{array}$} \\
\hline b & \multicolumn{4}{|c|}{ Not calculated } \\
\hline
\end{tabular}

controlled burns are calculated during the annual emission inventory and are included in the site total shown in table 3-1. USFS-SR personnel burned 8,867 acres across the site during 2003, compared to 4,505 acres in 2002.

\section{Ambient Air Quality}

Under existing regulations, SRS is not required to conduct onsite monitoring for ambient air quality; however, the site is required to show compliance with various air quality standards. To accomplish this, air dispersion modeling was conducted during 2003 for new emission sources or modified sources as part of the sources' construction permitting process. The modeling analysis showed that SRS air emission sources were in compliance with applicable regulations.

\section{Liquid Discharges}

\section{Description of Monitoring Program}

SRS monitors nonradioactive liquid discharges to surface waters through the National Pollutant Discharge Elimination System (NPDES), as mandated by the Clean Water Act. As required by EPA and SCDHEC, SRS has NPDES permits in place for discharges to the waters of the United States and South Carolina. These permits establish the specific sites to be monitored, parameters to be tested, and monitoring frequency - as well as analytical, reporting, and collection methods. Detailed requirements for each permitted discharge point can be found in the individual permits, which are available to the public through SCDHEC's Freedom of Information office at 803-734-5376.

In 2003, SRS discharged water into site streams and the Savannah River under two NPDES permits: one for industrial wastewater (SC0000175) and one for stormwater runoff-SCR00000 (industrial discharge). SCDHEC issued a new industrial wastewater permit to SRS effective December 1, 2003; the permit number did not change. Permit SC0000175 regulated 31 industrial wastewater outfalls from January through November and 25 industrial wastewater outfalls in December. Permit SCR100000 does not require sampling unless requested by SCDHEC to address specific discharge issues at a given construction site; SCDHEC did not request such sampling in 2003. This permit was sent out for public comment December 18, with comments due in early 2004. Permit ND0072125 is a "no discharge" water pollution control land application permit that regulates sludge application and related sampling at onsite sanitary wastewater treatment facilities. 
NPDES samples are collected in the field according to 40 CFR 136, the federal document that lists specific sample collection, preservation, and analytical methods acceptable for the type of pollutant to be analyzed. Chain-of-custody procedures are followed after collection and during transport to the analytical laboratory. The samples then are accepted by the laboratory and analyzed according to procedures listed in 40 CFR 136 for the parameters required by the permit.

\section{Monitoring Results}

SRS reports analytical results to SCDHEC through a monthly discharge monitoring report (EPA Form $3320-1$ ). Results from only 10 of the 3,828 sample analyses performed during 2003 exceeded permit limits. A list of the 2003 NPDES exceedances appears in table 3-4. SRS achieved a 99.7-percent compliance rate-higher than the DOE-mandated 98-percent rate. Seven of the exceedances are listed as toxicity failures, but none of these failures were due to toxic causes. The other three exceedances resulted from one sampling event at one outfall.

One hundred percent of the required stormwater discharge samples were collected and analyzed during 2003. SCDHEC has not mandated permit limits for stormwater outfalls.

During the first and fourth quarters of 2003, dewatered sludge was sampled and analyzed for pollutants of concern, and approximately 37.5 cubic yards of sludge was applied to the land. No sludge was applied during the second and third quarters. The analytical results indicated that pollutant concentrations were within regulatory limits. 
Table 3-4

2003 Exceedances of SCDHEC-Issued NPDES Permit Liquid Discharge Limits at SRS

\begin{tabular}{|c|c|c|c|c|c|}
\hline $\begin{array}{l}\text { Department/ } \\
\text { Division }\end{array}$ & Outfall & Date & Analysis & Possible Cause & Corrective Action \\
\hline SUD & $A-11$ & March 3 & C-TOX & $\begin{array}{l}\text { Sedimentation resulting } \\
\text { from heavy rains }\end{array}$ & $\begin{array}{l}\text { Sample location moved to } \\
\text { sheet pile dam }\end{array}$ \\
\hline SUD & $A-11$ & March 17 & C-TOX & $\begin{array}{l}\text { Sedimentation resulting } \\
\text { from heavy rains }\end{array}$ & $\begin{array}{l}\text { Sample location moved to } \\
\text { sheet pile dam }\end{array}$ \\
\hline Closure & $\mathrm{F}-08$ & August 13 & $\begin{array}{l}\text { Copper } \\
\text { (monthly } \\
\text { average) }\end{array}$ & $\begin{array}{l}\text { Well-cleaning discharge } \\
\text { flushing to outfall }\end{array}$ & Not yet determined \\
\hline Closure & $\mathrm{F}-08$ & August 13 & $\begin{array}{l}\text { Copper } \\
\text { (daily } \\
\text { maximum) }\end{array}$ & $\begin{array}{l}\text { Well-cleaning discharge } \\
\text { flushing to outfall }\end{array}$ & Not yet determined \\
\hline Closure & $\mathrm{F}-08$ & August 13 & $\begin{array}{l}\text { Lead } \\
\text { (monthly } \\
\text { average) }\end{array}$ & $\begin{array}{l}\text { Well-cleaning discharge } \\
\text { flushing to outfall }\end{array}$ & Not yet determined \\
\hline SRTC & $A-01^{a}$ & Sept. 22, 29 & C-TOX & $\begin{array}{l}\text { Analysis invalid due to } \\
\text { unhealthy D. ambigua } \\
\text { cultures at subcontract lab }\end{array}$ & $\begin{array}{l}\text { Improve health of ambigua } \\
\text { cultures at subcontract lab } \\
\text { (ongoing process) }\end{array}$ \\
\hline SUD & $A-11^{a}$ & Sept. 22, 29 & C-TOX & $\begin{array}{l}\text { Analysis invalid due to } \\
\text { unhealthy D. ambigua } \\
\text { cultures at subcontract lab }\end{array}$ & $\begin{array}{l}\text { Improve health of ambigua } \\
\text { cultures at subcontract lab } \\
\text { (ongoing process) }\end{array}$ \\
\hline SUD & $\mathrm{G}-10^{\mathrm{a}}$ & Sept. 22, 29 & C-TOX & $\begin{array}{l}\text { Analysis invalid due to } \\
\text { unhealthy D. ambigua } \\
\text { cultures at subcontract lab }\end{array}$ & $\begin{array}{l}\text { Improve health of ambigua } \\
\text { cultures at subcontract lab } \\
\text { (ongoing process) }\end{array}$ \\
\hline SUD & $\mathrm{G}-10^{\mathrm{a}}$ & Sept. 22, 29 & A-TOX & $\begin{array}{l}\text { Analysis invalid due to } \\
\text { unhealthy D. ambigua } \\
\text { cultures at subcontract lab }\end{array}$ & $\begin{array}{l}\text { Improve health of ambigua } \\
\text { cultures at subcontract lab } \\
\text { (ongoing process) }\end{array}$ \\
\hline SUD & $A-11$ & Nov. 10 & C-TOX & $\begin{array}{l}\text { Unknown - Subsequent } \\
\text { metals analysis indicated } \\
\text { no cause of toxicity }\end{array}$ & None \\
\hline
\end{tabular}

Key: A-TOX - Acute Toxicity; C-TOX - Chronic toxicity; TSS - Total suspended solids

a September (2003) toxicity samples were invalid because of problems with D. ambigua cultures at the subcontract laboratory. Although two analyses were performed at each outfall (A-01, A-11, and G-10), there will be only one exceedance at each outfall for failure to provide required analytical data as required by the permit. 


\title{
Chapter 4
}

\section{Environmental Surveillance}

\author{
Pete Fledderman, Donald Padgett, and Monte Steedley \\ Environmental Services Section \\ Timothy Jannik \\ Savannah River Technology Center \\ Robert Turner \\ Site Utilities Department
}

$\mathrm{E}$ NVIRONMENTAL surveillance at the Savannah River Site (SRS) is designed to survey and quantify any effects that routine and nonroutine operations could have on the site and on the surrounding area and population. Site surveillance activities are divided into radiological and nonradiological programs.

As part of the radiological surveillance program, routine surveillance of all radiation exposure pathways is performed on all environmental media that could lead to a measurable annual dose at and beyond the site boundary.

Nonradioactive environmental surveillance at SRS involves the sampling and analysis of surface water, drinking water, sediment, groundwater, and fish. Results from the analyses of surface water, drinking water, sediment, and fish are discussed in this chapter. A description of the groundwater monitoring program analysis results can be found in chapter 6 , "Groundwater."

The Environmental Services Section's Environmental Monitoring and Analysis (EMA) group and the Savannah River Technology Center (SRTC) perform surveillance activities. The Savannah River also is monitored by other groups, including the South Carolina Department of Health and Environmental Control (SCDHEC), the Georgia Department of Natural Resources, and the Academy of Natural Sciences of Philadelphia (ANSP).

A complete description of the EMA surveillance program, including sample collection and analytical procedures, can be found in section 1105 of the Savannah River Site Environmental Monitoring Section Plans and Procedures, WSRC-3Q1-2, Volume 1 (SRS EM Program). Brief summaries of analytical results are presented in this chapter; complete data sets can be found in tables on the $\mathrm{CD}$ accompanying this report.

\section{Radiological Surveillance}

\section{Air}

\section{Description of Surveillance Program}

EMA maintains a network of sampling stations in and around SRS to monitor the concentration of tritium and radioactive particulate materials in the air. In October 2003, a number of changes were made to the air surveillance program, including the following:

- Sampling was discontinued at two locations (West Jackson and Windsor Road), reducing the number of air surveillance sites from 17 to 15 .

- The sampling frequency for air filters and activated charcoal canisters was changed from weekly to biweekly at the remaining air surveillance sites.

- The sampling frequency for rainwater was changed from biweekly to monthly.

\section{Surveillance Results}

Except for tritium, specific radionuclides were not routinely detectable at the site perimeter. Both onsite and offsite activity concentrations were similar to levels observed in previous years.

Average gross alpha and beta results were slightly lower in 2003 than in 2002. However, they are consistent with historical results, which demonstrate long-term variability.

Cesium-137 was the only manmade gamma-emitting radionuclide observed in 2003, and was observed in only one site perimeter sample. These results are consistent with historical results, which indicate only a small number of samples with detectable activity.

Detectable alpha-emitting radionuclide activity, primarily uranium isotopes, was observed in five samples. Americium-241 was detected at one location on the site perimeter; curium-244 was detected at one 
offsite location; and uranium-234 was detected in three site perimeter locations. Generally, these concentrations were consistent with historical results. All isotopes at the remaining locations were below detection levels. As observed in previous years, none of the samples showed strontium-89,90 above the minimum detectable concentration (MDC).

Tritium-in-air results for 2003 were similar to those observed in 2002. Tritium was detected at every sampling location, although not every sample from a particular location had detectable tritium. As in previous years, the Burial Ground North location showed average and maximum concentrations significantly higher than those observed at other locations. This was expected because of its proximity to SRS's tritium facilities, which are near the center of the site. Consistent with the SRS source term, tritium concentrations generally decrease with increasing distance from the tritium facilities.

\section{Rainwater}

\section{Description of Surveillance Program}

SRS maintains a network of rainwater sampling sites as part of the air surveillance program. These stations are used to measure deposition of radioactive materials.

\section{Surveillance Results}

Gamma-Emitting Radionuclides No detectable manmade gamma-emitting radionuclides were observed in rainwater samples in 2003.

Except for the Burial Ground North results that were discussed in last year's (2002) site environmental report, the gross alpha and gross beta results from 2003 were consistent with those of 2002. Although the 2003 results generally were slightly higher than those of 2002, no long-term increasing or decreasing trend was evident. This implies that the observed values are natural background and does not indicate any contribution directly attributable to SRS.

Except for plutonium-238 at one location, all actinides were below detection levels in 2003.

As in 2002, no detectable levels of strontium-89,90 were observed in rainwater samples during 2003.

As in previous years, tritium-in-rain values were highest near the center of the site. This is consistent with the H-Area effluent release points that routinely release tritium. Tritium was detected at every sampling location, although not every sample from a particular location had detectable tritium. As with tritium in air, concentrations generally decreased as distance from the effluent release point increased.

\section{Gamma Radiation}

\section{Description of Surveillance Program}

Ambient gamma exposure rates in and around SRS are monitored by a network of thermoluminescent dosimeters (TLDs).

\section{Surveillance Results}

Exposures at all TLD monitoring locations show some variation based on normal site-to-site and year-to-year differences in the components of natural ambient gamma exposure levels. Exposure rates varied between 55 and 114 mrem per year.

In general, the 2003 ambient gamma radiation monitoring results indicated gamma exposure rates slightly lower than those observed at the same locations in 2002. However, these results generally are consistent with previously published historical results, and indicate that-except in the case of population centers-no significant difference in average exposure rates is observed between monitoring networks.

\section{E-Area Stormwater Basins}

\section{Description of Surveillance Program}

Stormwater accumulating in the E-Area stormwater basins is monitored because of potential contamination.

\section{Surveillance Results}

There are no active discharges to the E-Area stormwater basins; the primary contributor to basin water is rainwater runoff. Rain events did not supply enough water to the E-03 and E-06 basins for sampling purposes in 2003, so no samples were obtained from these locations. The highest mean tritium concentration in 2003, $1.28 \mathrm{E}+05 \mathrm{pCi} / \mathrm{L}$, was detected in basin E-05 and is attributed to activities at the nearby Four Mile Creek phytoremediation project. This concentration is similar to 2003's high mean tritium concentration for the same location. Mean cobalt-60, cesium-137, and gross alpha concentrations all were below the MDCs.

Gross beta concentrations for the E-Area stormwater basins declined slightly from last year's concentrations, but were typical of long-term trends. Overall, actinides were slightly lower than or consistent with last year's concentrations, and all were below their respective MDCs. 


\section{Site Streams}

\section{Description of Surveillance Program}

Continuous surveillance is used on several SRS streams to monitor below process areas and to detect and quantify levels of radioactivity in liquid effluents being transported to the Savannah River. In September 2003 , a number of changes were made to the radiological liquid surveillance program, including the following:

- Sampling at two sites-McQueen Branch and C Canal-was discontinued, reducing the number of stream surveillance sites from 20 to 18 .

- Sampling frequency at the remaining sites was changed from biweekly to monthly.

\section{Surveillance Results}

Further investigation into the elevated 2002 gross alpha and gross beta results from the U3R-1A location proved inconclusive. No offsite activities were identified that would have affected sample results. In 2003, the gross alpha and beta concentrations at this location returned to normal levels when compared with the years before 2002. All tritium concentrations at U3R-1A were below detection in 2003.

Mean 2003 gross alpha and gross beta concentrations at the other surveillance locations generally were lower than last year's, but consistent with historical data.

Cesium-137 was detected at four locations, but the mean concentrations at two of the locations were lower than last year. The two elevated mean concentrations were at Four Mile-A7 and Four Mile-2. The Four Mile-A7 mean concentration was consistent with historical data. The Four Mile-2 mean concentration, though higher than historical data, was only $2.02 \mathrm{E}+01$ $\mathrm{pCi} / \mathrm{L}$. Cobalt- 60 concentrations were below detection.

A technetium-99 measurement program begun in 2001 to establish historical technetium-99 levels continued in 2003. All the stream technetium-99 results, as well as the iodine-129 results, were below MDC.

In 2001 and 2002, technetium-99 and iodine-129 analyses were run on streamwater samples, but were not reported in the 2001 and 2002 environmental reports. Iodine-129 was not detected in 2001 or 2002. Technetium-99 was detected in Four Mile Creek. A supplemental table containing the 2001 and 2002 iodine-129 information is provided on the $\mathrm{CD}$ accompanying this (2003) report.

Upper Three Runs-F3 mean concentrations indicated the presence of uranium-234, uranium-235, ura- nium-238, and plutonium-238. However, the uranium-238 and plutonium-238 values were consistent with historical data, while the uranium-234 and uranium-235 mean concentrations indicated a minor elevation, with mean concentrations of $5.81 \mathrm{E}-01 \mathrm{pCi} / \mathrm{L}$ and $3.50 \mathrm{E}-02 \mathrm{pCi} / \mathrm{L}$, respectively. Americium-241 and curium-244 results were below detection. Strontium-89,90 was detected at two Four Mile Creek locations, but the results generally were consistent with historical values.

\section{Seepage Basin and Solid Waste Disposal Facility Radionuclide Migration}

To incorporate the migration of radioactivity to site streams into total radioactive release quantities, EMA monitored and quantified the migration of radioactivity from site seepage basins and the Solid Waste Disposal Facility (SWDF) in 2003 as part of its stream surveillance program. During 2003, tritium, strontium89,90 , and cesium- 137 were detected in migration releases. Measured iodine-129 results, however, all were below the MDC for the laboratory's analytical procedure. Therefore, the amount last measured (in 1996) was used for dose calculations.

Figure 4-1 is a graphical representation of releases of tritium via migration to site streams for the years 1994-2003. During 2003, the total quantity of tritium migrating from the seepage basins and SWDF was $2,783 \mathrm{Ci}$, compared to $2,007 \mathrm{Ci}$ in 2002 . This increase is attributed primarily to the increase in rainfall during 2003 , compared to the previous few years.

Radioactivity previously deposited in the F-Area and $\mathrm{H}$-Area seepage basins and SWDF continues to migrate via the groundwater and to outcrop into Four Mile Creek and into Upper Three Runs.

Measured migration of tritium into Four Mile Creek in 2003 occurred as follows:

- from F-Area seepage basins, $555 \mathrm{Ci}-\mathrm{a} 146-$ percent increase from the 2002 total of $226 \mathrm{Ci}$

- from H-Area seepage basin 4 and SWDF, 390 $\mathrm{Ci}-\mathrm{a}$ three-percent increase from the 2002 total of $381 \mathrm{Ci}$

- from H-Area seepage basins 1, 2, and 3, $206 \mathrm{Ci}-$ a 117-percent increase from the 2002 total of 95 $\mathrm{Ci}$

The measured migration from the north side of SWDF and the General Separations Area (GSA) into Upper Three Runs in 2003 was $462 \mathrm{Ci}$, a 68-percent increase from the 2002 total of $275 \mathrm{Ci}$. (The GSA is in the central part of SRS and contains all waste disposal facilities, chemical separations facilities, associated 


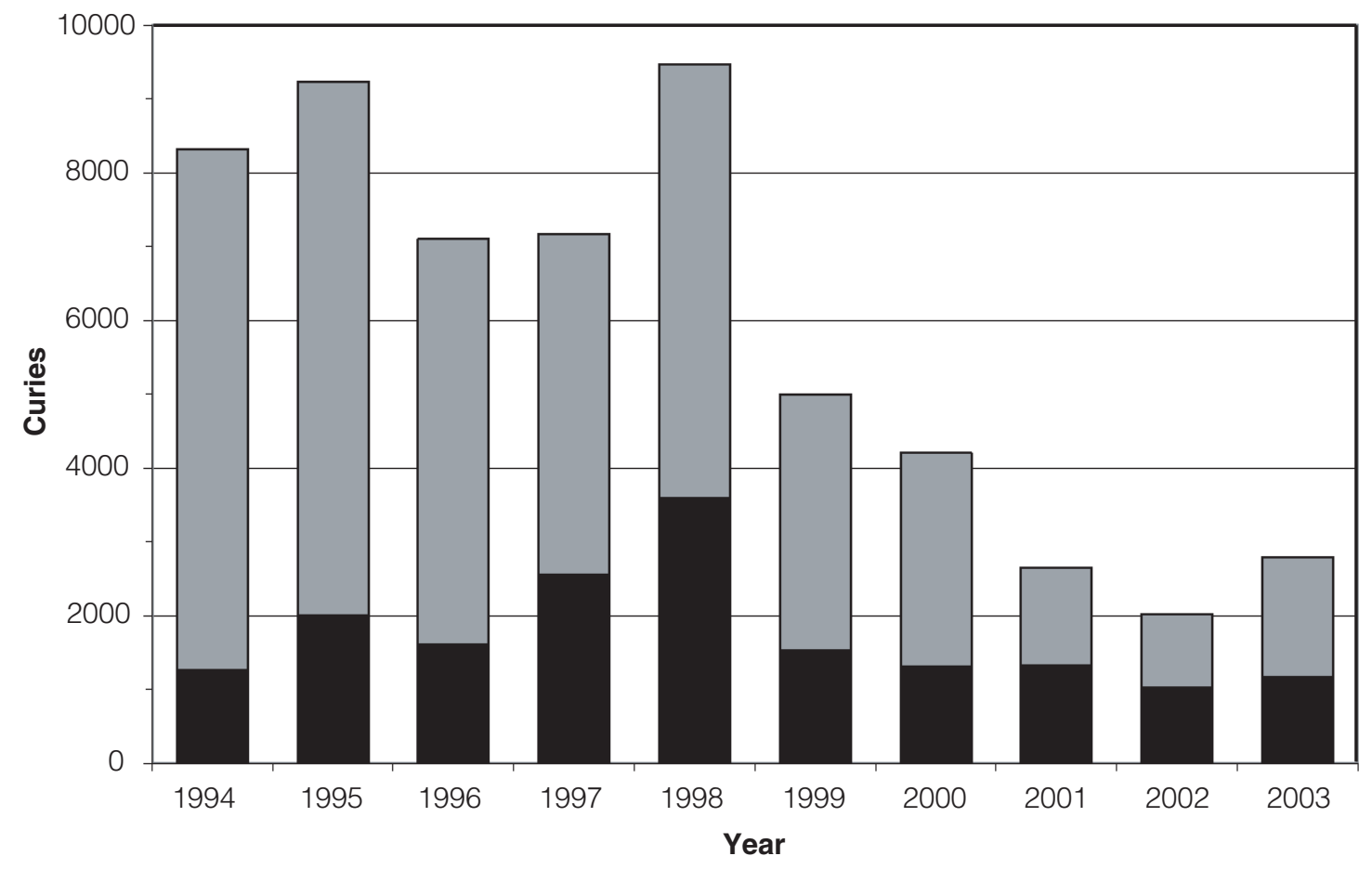

$\square$ K-Area Seepage Basins $\square$ Separations Seepage Basins and SWDF

Figure 4-1 Tritium from SRS Seepage Basins and SWDF to Site Streams, 1994-2003

high-level waste storage facilities, and numerous other sources of radioactive material.)

The total amount of strontium-89,90 entering Four Mile Creek from the GSA seepage basins and SWDF during 2003 was estimated to be $94.1 \mathrm{mCi}$ - a 93percent increase from the 2002 level of $32.8 \mathrm{mCi}$. Migration releases of strontium-89,90 vary from year to year but have remained below $100 \mathrm{mCi}$ the past 5 years (see data table on $\mathrm{CD}$ accompanying this report).

In addition, a total of $69.8 \mathrm{mCi}$ of cesium-137 was estimated to have migrated from the GSA seepage basins and SWDF in 2003. This was an increase of 237 percent from the 2002 total of $20.7 \mathrm{mCi}$.

As discussed previously, iodine-129 was not measured in Four Mile Creek water samples during 2003. It was assumed that $78.2 \mathrm{mCi}$ migrated from the GSA seepage basins in 2003. This was the amount last measured (during 1996).

During 2003, technetium-99 was not detected in the migration samples from the F-Area and H-Area seepage basins

K-Area Drain Field and Seepage Basin Liquid purges from the K-Area disassembly basin were released to the K-Area seepage basin in 1959 and
1960. From 1960 until 1992, purges from the K-Area disassembly basin were discharged to a percolation field below the K-Area retention basin. Tritium migration from the seepage basin and the percolation field is measured in Pen Branch. The 2003 migration total of 1,170 $\mathrm{Ci}$ represents a 37-percent increase from the $853 \mathrm{Ci}$ recorded in 2002.

C-Area, L-Area, and P-Area Seepage Basins Liquid purges from the C-Area, L-Area, and P-Area disassembly basins were released periodically to their respective seepage basins from the 1950s until 1970.

Migration releases from these basins no longer are quantified; however, they are accounted for in the stream transport totals.

\section{Transport of Actinides in Streams}

Uranium, plutonium, americium, and curium are analyzed annually from each stream location. Values for 2003 were consistent with historical data.

\section{Savannah River}

\section{Description of Surveillance Program}

Continuous surveillance is performed along the Savannah River at points above and below SRS and 
includes the point at which liquid discharges from Georgia Power Company's Vogtle Electric Generating Plant enter the river.

\section{Surveillance Results}

Tritium is the predominant radionuclide detected above background levels in the Savannah River. The annual mean tritium concentration at RM-118.8 in 2003 was about 4 percent of the drinking water standard.

The average gross alpha concentration at each river location was below the MDC in 2003.

Gross beta activities at all locations were slightly above the MDC for the analysis in 2003. Mean and maximum concentrations were similar at all locations, indicating that there was no significant release of betaemitting nuclides attributable to SRS discharges.

The mean concentrations for cesium-137 and cobalt60 were below their MDCs for analysis in 2003 at all Savannah River locations.

Activity levels for strontium-89,90 and for all actinides fluctuated around their respective MDCs and generally were at or below last year's concentrations.

\section{Tritium Transport in Streams}

Tritium is introduced into SRS streams and the Savannah River from production areas on site. Because of the mobility of tritium in water and the quantity of the radionuclide released during the years of SRS operations, a tritium balance has been performed annually since 1960 . The balance is evaluated among the following alternative methods of calculation:

- $\quad$ tritium releases from effluent release points and calculated seepage basin and SWDF migration (direct releases)

- $\quad$ tritium transport in SRS streams and the last sampling point before entry into the Savannah River (stream transport)

- $\quad$ tritium transport in the Savannah River downriver of SRS after subtraction of any measured contribution above the site (river transport)

The total combined tritium releases in 2003 (direct discharges and migration from seepage basins and SWDF) were 4,319 Ci, compared to 3,096 Ci in 2002.

During 2003, the total tritium transport in SRS streams increased by approximately 45 percent (from $2,857 \mathrm{Ci}$ in 2002 to $4,139 \mathrm{Ci}$ in 2003).

The 2003 measured tritium transport in the Savannah River $(5,910 \mathrm{Ci})$ was more than the stream transport total. Most of this difference is attributed to Plant Vogtle's 2003 tritium releases, which totaled approximately $1,900 \mathrm{Ci}$.

SRS tritium transport data for 1960-2003 are depicted in figure 4-2, which shows summaries of the past 44 years of direct releases, stream transport, and river transport determined by EMA.

General agreement between the three calculational methods of annual tritium transport-measurements at the source, stream transport, and river transportserves to validate SRS sampling schemes and counting results. Differences between the various methods can be attributed to uncertainties arising in the collection and analytical processes, including the determination of water flow rates and of varying transport times.

\section{Drinking Water}

\section{Description of Surveillance Program}

EMA collected drinking water samples in 2003 from locations at SRS and at water treatment facilities that use Savannah River water. Potable water was analyzed at offsite treatment facilities to ensure that SRS operations did not adversely affect the water supply and to provide voluntary assurance that drinking water did not exceed EPA drinking water standards for radionuclides.

Onsite drinking water sampling consisted of quarterly grab samples at large treatment plants in A-Area, DArea, and K-Area and annual grab samples at wells and small systems. Collected monthly off site were composite samples from

- two water treatment plants downriver of SRS that supply treated Savannah River water to Beaufort and Jasper counties in South Carolina and to Port Wentworth, Georgia

- the North Augusta (South Carolina) Water Treatment Plant

\section{Surveillance Results}

All drinking water samples collected by EMA were screened for gross alpha and gross beta concentrations to determine if activity levels warrant further analysis. No samples collected in 2003 exceeded EPA's $1.50 \mathrm{E}+01-\mathrm{pCi} / \mathrm{L}$ alpha activity limit or $5.00 \mathrm{E}+01-\mathrm{pCi} /$ L beta activity limit. Also, no onsite or offsite drinking water samples collected and analyzed by EMA in 2003 exceeded the 2.00E+04-pCi/L EPA tritium limit, and no drinking water samples collected and analyzed by EMA for strontium 89,90 in 2003 exceeded the MDC.

No cobalt-60, cesium-137, or plutonium-239 was detected in any drinking water samples collected 


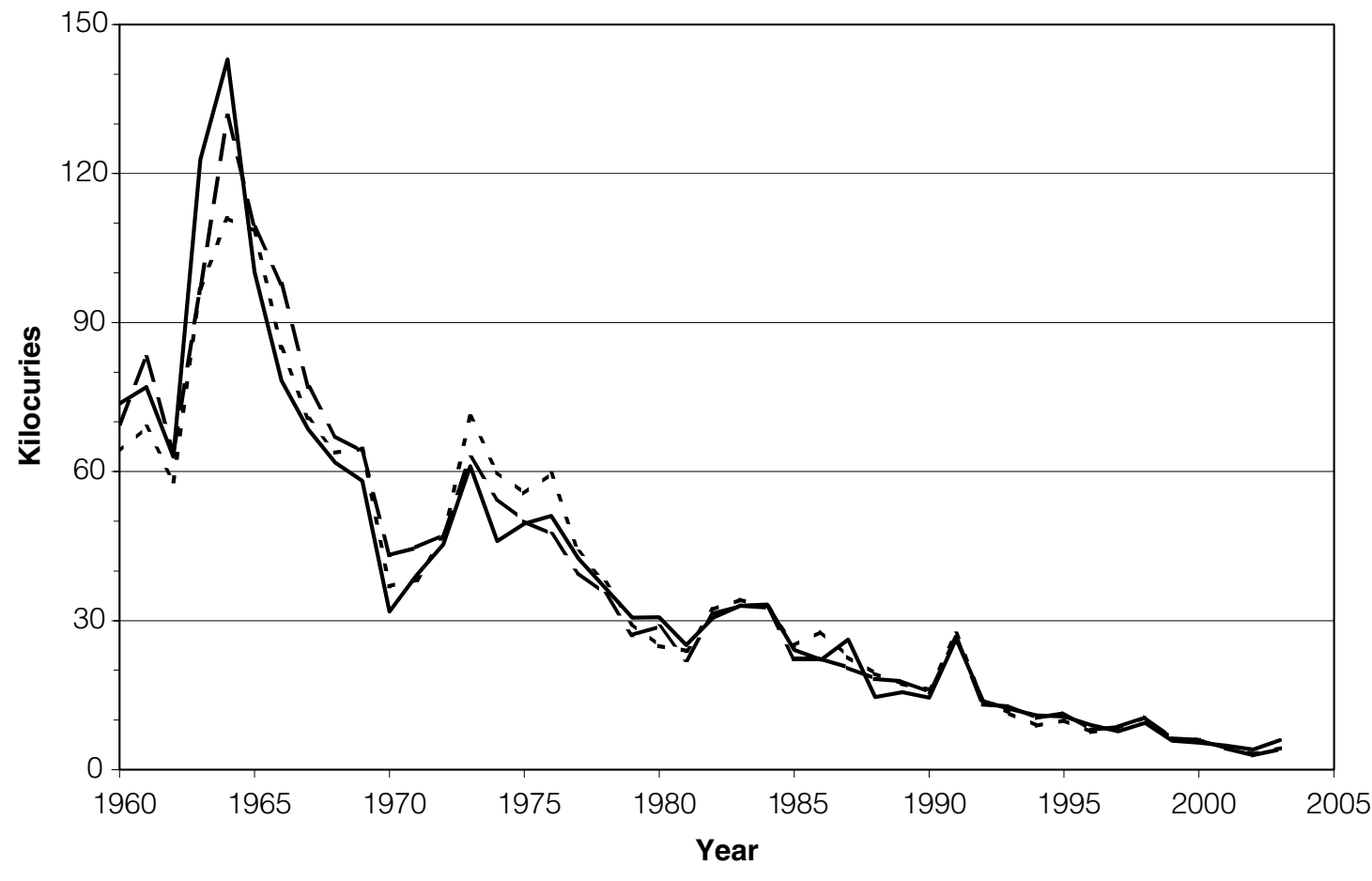

- - - Direct Releases Plus Migration - -Stream Transport =-River Transport

Figure 4-2 SRS Tritium Transport Summary, 1960-2003

SRS has maintained a tritium balance of direct releases plus migration, stream transport, and river transport since 1960 in an effort to account for and trend tritium releases in liquid effluents from the site. The general trend over time is attributable to (1) variations in tritium production at the site (production stopped in the late 1980s); (2) the implementation of effluent controls, such as seepage basins, beginning in the early 1960s; and (3) the continuing depletion and decay of the site's tritium inventory.

during 2003. In general, uranium isotopes, plutonium-238, and americium-241 were not detected, although samples from a few locations showed detectable levels of these nuclides.

\section{Terrestrial Food Products}

\section{Description of Surveillance Program}

The terrestrial food products surveillance program consists of radiological analyses of food product samples typically found in the Central Savannah River Area (CSRA). These food products include meat (beef), fruit, and green vegetables (collards). Data from the food product surveillance program are not used to show direct compliance with any dose standard; however, the data can be used as required to verify dose models and determine environmental trends.

Samples of food-including meat (beef), fruit (melons or peaches), and a green vegetable (collards) - are collected from one location within each of four quadrants and from a control location within an extended (to 25 miles beyond the perimeter) southeast quadrant. All food samples are collected annually except milk.

Food samples are analyzed for the presence of gamma-emitting radionuclides, tritium, strontium89,90 , plutonium-238, and plutonium-239.

\section{Surveillance Results}

The only manmade gamma-emitting radionuclide detected in food products in 2003 was cesium-137, which was found in collards from two sampling locations. Strontium-89,90 was detected in collards at four locations, while tritium was detected in collards and milk at 21 locations. No other manmade radionuclides were detected in food products.

Tritium in milk and other samples is attributed primarily to releases from SRS. Tritium concentrations in collards and milk were similar to those of previous years. No tritium was detected in any other food sample. 
These results are similar to those of previous years.

\section{Aquatic Food Products}

\section{Description of Surveillance Program}

The aquatic food product surveillance program includes fish (freshwater and saltwater) and shellfish. To determine the potential dose and risk to the public from consumption, both types are sampled.

Nine surveillance points for the collection of freshwater fish are located on the Savannah River. Effective beginning in 2003, fish no longer are collected at onsite locations for this program.

\section{Surveillance Results}

Cesium-137 was the only manmade gamma-emitting radionuclide found in Savannah River edible composites. Strontium-89,90 and tritium were detected at most of the river locations. No manmade radionuclides were found above their MDCs in saltwater fish or shellfish. These results were similar to those of previous years.

\section{Deer and Hogs}

\section{Description of Surveillance Program}

Annual hunts, open to members of the general public, are conducted at SRS to control the site's deer and feral hog populations and to reduce animal-vehicle accidents. Before any animal is released to a hunter, EMA uses portable sodium iodide detectors to perform field analysis for cesium-137. Media samples (muscle and/or bone) are collected periodically for laboratory analysis based on a set frequency, on cesium-137 levels, and/or on exposure limit considerations.

\section{Surveillance Results}

A total of 1,128 deer and 106 feral hogs were taken during the 2003 site hunts. As observed during previous hunts, cesium-137 was the only manmade gamma-emitting radionuclide detected during laboratory analysis. Generally, the cesium-137 concentrations measured by the field and lab methods were comparable. Field measurements from all animals ranged from $1 \mathrm{pCi} / \mathrm{g}$ to $17.1 \mathrm{pCi} / \mathrm{g}$, while lab measurements ranged from $1 \mathrm{pCi} / \mathrm{g}$ to $18.2 \mathrm{pCi} / \mathrm{g}$. The average field cesium-137 concentration was $1.29 \mathrm{pCi} / \mathrm{g}$ in deer (with a maximum of $17.1 \mathrm{pCi} / \mathrm{g}$ ) and $1.18 \mathrm{pCi} / \mathrm{g}$ in hogs (with a maximum of $3.1 \mathrm{pCi} / \mathrm{g}$ ).

Strontium levels are determined in some of the animals analyzed for cesium-137. Typically, muscle and bone samples are collected for analysis from the same animals checked for cesium-137, and the samples are analyzed for strontium-89,90. As in previous years, strontium-89,90 was not quantified in muscle samples. Lab measurements of strontium-89,90 in bone ranged from a high of $11.6 \mathrm{pCi} / \mathrm{g}$ to a low of $2.56 \mathrm{pCi} / \mathrm{g}$.

\section{Turkeys/Beavers}

\section{Description of Surveillance Programs}

Wild turkeys have been trapped on site by the South Carolina Wildlife and Marine Resources Department and used to repopulate game areas in South Carolina and other states. The U.S. Department of Agriculture Forest Service-Savannah River harvests beavers in selected areas within the SRS perimeter to reduce the beaver population and thereby minimize dam-building activities that can result in flood damage to timber stands, to primary and secondary roads, and to railroad beds. However, both programs remained inactive in 2003 because of reduced needs.

\section{Soil}

\section{Description of Surveillance Program}

The SRS soil monitoring program provides

- data for long-term trending of radioactivity deposited from the atmosphere (both wet and dry deposition)

- information on the concentrations of radioactive materials in the environment

The concentrations of radionuclides in soil vary greatly among locations because of differences in rainfall patterns and in the mechanics of retention and transport in different types of soils. Because of this program's design, a direct comparison of data from year to year is not appropriate.

Soil samples are collected from four onsite locations, four site perimeter locations and two offsite locations.

\section{Surveillance Results}

Radionuclides in soil samples from 2003 were detected as follows:

- Cesium-137 at eight locations (on site/perimeter/ off site)

- Uranium-234, 235, and 238 at all locations

- Plutonium-238 at four onsite locations

- Plutonium-239 at eight locations (on site/ perimeter/off site)

These results are similar to those of previous years. 


\section{Settleable Solids}

\section{Description of Surveillance Program}

Settleable-solids monitoring in effluent water is required to ensure-in conjunction with routine sediment monitoring - that a long-term buildup of radioactive materials does not occur in stream systems.

DOE limits on radioactivity levels in settleable solids are $5 \mathrm{pCi} / \mathrm{g}$ above background for alpha-emitting radionuclides and $50 \mathrm{pCi} / \mathrm{g}$ above background for beta/gamma-emitting radionuclides.

Low total suspended solids (TSS) levels result in a small amount of settleable solids, so an accurate measurement of radioactivity levels in settleable solids is impossible. Based on this, an interpretation of the radioactivity-levels-in-settleable-solids requirement was provided to Westinghouse Savannah River Company (WSRC) by DOE in 1995. The interpretation indicated that TSS levels below 40 parts per million ( $\mathrm{ppm}$ ) were considered to be in de-facto compliance with the DOE limits.

To determine compliance with these limits, EMA uses TSS results-gathered as part of the routine National Pollutant Discharge Elimination System monitoring program-from outfalls co-located at or near radiological effluent points. If an outfall shows that TSS levels regularly are greater than $40 \mathrm{ppm}$, a radioactivity-levels-in-settleable-solids program and an increase in sediment monitoring will be implemented.

\section{Surveillance Results}

TSS sample results did not exceed $40 \mathrm{ppm}$ in 2003. The results indicate that SRS is in compliance with the DOE radioactivity-levels-in-settleable-solids requirement.

\section{Sediment}

\section{Description of Surveillance Program}

Sediment sample analysis measures the movement, deposition, and accumulation of long-lived radionuclides in stream beds and in the Savannah River bed. Significant year-to-year differences may be evident because of the continuous deposition and remobilization occurring in the stream and river beds - or because of slight variation in sampling locations - but the data obtained can be used to observe long-term environmental trends.

Sediment samples were collected at eight Savannah River locations and 13 site stream locations in 2003.

\section{Surveillance Results}

Cesium-137 and cobalt- 60 were the only manmade gamma-emitting radionuclides observed in river and stream sediments. The highest cesium-137 concentration in streams, $1.14 \mathrm{E}+02 \mathrm{pCi} / \mathrm{g}$, was detected in sediment from R-Canal. The highest level found on the river, 3.51E-01pCi/g, was at River Mile 134; the lowest levels were below detection at several locations. Generally, cesium-137 concentrations were higher in stream sediments than in river sediments. This is to be expected because the streams receive radionuclide-containing liquid effluents from the site. Most radionuclides settle out and deposit on the stream beds or at the streams' entrances to the swamp areas along the river.

Cobalt-60 was detected above the MDC in sediment from the following locations:

- Four Mile Creek Swamp Discharge

- Four Mile A-7A

- R-Canal

The highest cobalt- 60 concentration in streams, $2.45 \mathrm{E}-01 \mathrm{pCi} / \mathrm{g}$, was measured at Four Mile A-7A; concentrations at the most other sediment sampling locations were below detection.

Concentrations of strontium- 89,90 in stream sediment ranged from a high of $3.96 \mathrm{E}+00 \mathrm{pCi} / \mathrm{g}$ at the $\mathrm{FM}-\mathrm{A} 7$ location to lows below the MDC at most of the other locations.

Concentrations of plutonium-238 in stream sediment during 2003 ranged from a high of $1.33 \mathrm{E}+00 \mathrm{pCi} / \mathrm{g}$ at the Four Mile A-7A location to below detection at several locations. Concentrations of plutonium-239 ranged from a high of 7.05E-01 pCi/g at the Four Mile A-7A location to below detection at several locations. Uranium-234, 235, and 238 was detected at all locations.

Concentrations of radionuclides in river sediment during 2003 were similar to those of previous years.

Concentrations of all isotopes generally were higher in streams than in the river. As indicated in the earlier discussion of cesium-137, this is to be expected. Differences observed when these data are compared to those of previous years probably are attributable to the effects of resuspension and deposition, which occur constantly in sediment media. 


\section{Grassy Vegetation}

\section{Description of Surveillance Program}

The radiological program for grassy vegetation is designed to collect and analyze samples from onsite and offsite locations to determine radionuclide concentrations. Vegetation samples are obtained to complement the soil and sediment samples in order to determine the environmental accumulation of radionuclides and help confirm the dose models used by SRS. Bermuda grass is preferred because of its importance as a pasture grass for dairy herds.

Vegetation samples are obtained from

- locations containing soil radionuclide concentrations that are expected to be higher than normal background levels

- locations receiving water that may have been contaminated

\section{Surveillance Results}

Radionuclides in the grassy vegetation samples collected in 2003 were detected as follows:

- Tritium at one perimeter location and offsite at Savannah

- Cesium-137 (the only manmade gamma-emitting radionuclide detected) at one perimeter location

- Strontium-89/90 at two perimeter locations

- Uranium-234 at all locations except D-Area perimeter

- Uranium-235 at the onsite location (Burial Ground)

- Uranium-238 at all locations

These results are similar to those of previous years.

\section{Savannah River Swamp Surveys}

The Creek Plantation, a privately owned land area located along the Savannah River, borders part of the southern boundary of SRS. In the 1960s, an area of the Savannah River Swamp on Creek Plantationspecifically, the area between Steel Creek Landing and Little Hell Landing — was contaminated by SRS operations. During high river levels, water from Steel Creek flowed along the lowlands comprising the swamp, resulting in the deposition of radioactive material. SRS studies estimated that a total of approximately $25 \mathrm{Ci}$ of cesium- 137 and $1 \mathrm{Ci}$ of cobalt-60 were deposited in the swamp.

Comprehensive and cursory surveys of the swamp have been conducted periodically since 1974 . These surveys measure radioactivity levels to determine changes in the amount and/or distribution of radioactivity in the swamp.

Because of high water in the swamp, no survey was conducted in 2003.

\section{Nonradiological Surveillance}

\section{Air}

SRS currently does not conduct onsite surveillance for nonradiological ambient air quality. However, to ensure compliance with SCDHEC air quality regulations and standards, SRTC conducted air dispersion modeling for all site sources of criteria pollutants and toxic air pollutants in 1993. This modeling indicated that all SRS sources were in compliance with air quality regulations and standards. Since that time, additional modeling conducted for new sources of criteria pollutants and toxic air pollutants has demonstrated continued compliance by the site with current applicable regulations and standards. The states of South Carolina and Georgia continue to monitor ambient air quality near the site as part of a network associated with the federal Clean Air Act.

\section{Surface Water}

SRS streams and the Savannah River are classified by SCDHEC as "Freshwaters," which are defined as surface water suitable for

- primary and secondary contact recreation and as a drinking water source after conventional treatment in accordance with SCDHEC requirements

- $\quad$ fishing and survival and propagation of a balanced indigenous aquatic community of fauna and flora

- industrial and agricultural uses

Appendix A, "Applicable Guidelines, Standards, and Regulations," provides some of the specific guidelines used in water quality surveillance, but because some of these guidelines are not quantifiable, they are not tracked.

\section{Surveillance Results}

Analyses of the surface water data continue to indicate that SRS discharges are not significantly affecting the water quality of the onsite streams or the river.

\section{Drinking Water}

Most of the drinking water at SRS is supplied by three systems that have treatment plants in A-Area, D-Area, and K-Area. The site also has 15 small drinking water 
facilities that serve populations of fewer than 25 persons.

\section{Surveillance Results}

All samples collected from SRS drinking water systems during 2003 were in compliance with SCDHEC and EPA water quality limits (maximum contaminant levels).

\section{Sediment}

The nonradiological sediment surveillance program provides a method to determine the deposition, movement, and accumulation of nonradiological contaminants in stream systems.

\section{Surveillance Results}

In 2003, as in the previous 6 years, no pesticides or herbicides were found to be above the quantitation limits in sediment samples. Metals analyses for the 2003 are comparable to those of the previous 6 years.

\section{Fish}

EMA personnel analyze the flesh of fish caught from onsite streams and ponds and from the Savannah River to determine concentrations of mercury in the fish. The fish analyzed represent the most common edible species of fish in the Central Savannah River Area (freshwater) and at the mouth of the Savannah River (saltwater).

\section{Surveillance Results}

In 2003, 149 fish were caught from the Savannah River and analyzed for mercury. Concentrations of mercury contained in fish samples from 2003 were slightly higher-from bass at Stokes Bluff, Beaver Dam Creek Mouth, and Four Mile Creek Mouth and catfish at Augusta Lock and Dam-than in 2002, but remained similar to those of previous years.

\section{Academy of Natural Sciences of Philadelphia River Quality Surveys}

\section{Description of Surveys}

ANSP has conducted biological and water quality surveys of the Savannah River since 1951. The surveys are designed to assess potential effects of SRS contaminants and warm-water discharges on the general health of the river and its tributaries. This is accomplished by looking for

- patterns of biological disturbance that are geographically associated with the site

- patterns of change over seasons or years that indicate improving or deteriorating conditions

Samples collected for the 2001 survey were analyzed by ANSP during 2003. No adverse conditions were identified in the 2001 samples. No surveys were conducted by ANSP in 2002 because no contract was in place; SRS personnel, however, collected and archived diatoms (monthly) and macroinvertebrates (twice during the year), as had been customary.

Aquatic macroinvertebrate and fish surveys were conducted by ANSP in 2003, but the results were not available in time for publication in this report. SRS personnel collected and archived aquatic macroinvertebrates during the 2003 spring sampling period. Diatoms were collected monthly and archived by WSRC, while the August collection (per contractual agreement) was sent to the Stroud Water Research Center near Philadelphia for identification. 


\title{
Chapter 5
}

\section{Potential Radiation Doses}

\author{
Timothy Jannik, Patricia Lee, and Ali Simpkins \\ Savannah River Technology Center
}

$\mathrm{T}$

THIS chapter presents the potential doses to offsite individuals and the surrounding population from the 2003 Savannah River Site (SRS) atmospheric and liquid radioactive releases. Also documented are potential doses from special-case exposure scenarios-such as the consumption of deer meat, creek mouth fish, and goat milk.

Unless otherwise noted, the generic term "dose" used in this report includes both the committed effective dose equivalent (50-year committed dose) from internal deposition of radionuclides and the effective dose equivalent attributable to sources external to the body. Use of the effective dose equivalent allows doses from different types of radiation and to different parts of the body to be expressed on the same basis.

Descriptions of the effluent monitoring and environmental surveillance programs discussed in this chapter can be found in chapter 3, "Effluent Monitoring," and chapter 4, "Environmental Surveillance." A complete description of how potential doses are calculated can be found in section 1108 of the Savannah River Site Environmental Monitoring Section Plans and Procedures, WSRC-3Q1-2, Volume 1 [SRS EM Program, 2001]. All potential dose calculation results are presented in data tables on the $\mathrm{CD}$ accompanying this report.

Applicable dose regulations can be found in appendix A, "Applicable Guidelines, Standards, and Regulations," of this document.

\section{Calculating Dose}

Potential offsite doses from SRS effluent releases of radioactive materials (atmospheric and liquid) are calculated for the following scenarios:

- hypothetical maximally exposed individual

- $\quad$ 80-km (50-mile) population

Because the U.S. Department of Energy (DOE) has adopted dose factors only for adults, SRS calculates maximally exposed individual and collective doses as if the entire $80-\mathrm{km}$ population consisted of adults [DOE, 1988]. For the radioisotopes that contribute the most to SRS's estimated maximum individual doses (i.e., tritium and cesium-137), the dose to infants would be approximately two to three times more than to adults. The dose to older children becomes progressively closer to the adult dose.

For dose calculations, unspecified alpha releases were assigned the plutonium-239 dose factor, and unspecified beta releases were assigned the strontium-90 factor. Accounting for the alpha and beta emitters in this way generates an overestimated dose attributed to releases from SRS because

- plutonium-239 and strontium-90 have the highest dose factors among the common alpha- and beta-emitting radionuclides

- a part of the unidentified activity probably is not from SRS operations but from naturally occurring

\section{Dose to the Hypothetical Maximally Exposed Individual}

When calculating radiation doses to the public, SRS uses the concept of the maximally exposed individual; however, because of the conservative lifestyle assumptions used in the dose models, no such person is known to exist. The parameters used for the dose calculations are

For airborne releases: Someone who lives at the SRS boundary 365 days per year and consumes large amounts of milk, meat, and vegetables produced at that location

For liquid releases: Someone who lives downriver of SRS (near River Mile 118.8) 365 days per year, drinks 2 liters of untreated water per day from the Savannah River, consumes a large amount of Savannah River fish, and spends the majority of time on or near the river

To demonstrate compliance with the DOE Order 5400.5 all-pathway dose standard of 100 mrem per year, SRS conservatively combines the airborne pathway and liquid pathway dose estimates, even though the two doses are calculated for hypothetical individuals residing at different geographic locations. 
radionuclides, such as potassium-40 and radon progeny

SRS also uses adult consumption rates for food and drinking water and adult usage parameters to estimate intakes of radionuclides. These intake values and parameters were developed specifically for SRS based on a regional survey [Hamby, 1991].

\section{Dose Calculation Methods}

To calculate annual offsite doses, SRS uses transport and dose models developed for the commercial nuclear industry [NRC, 1977]. The models are described in SRS EM Program, 2001.

\section{Meteorological Database}

To show compliance with DOE environmental orders, potential offsite doses from releases of radioactivity to the atmosphere were calculated with quality-assured meteorological data for A-Area, K-Area (used for releases from C-Area, K-Area, and L-Area) and $\mathrm{H}$-Area (used for releases from all other areas). The meteorological databases used were for the years 1997-2001, reflecting the most recent 5-year compilation period.

To show compliance with EPA regulations, only the $\mathrm{H}$-Area database was used in the calculations because the dosimetry code that EPA requires to be used is limited to a single release location. The H-Area meteorological database is provided on the $\mathrm{CD}$ accompanying this report.

\section{Population Database and Distribution}

Collective, or population, doses from atmospheric releases are calculated for the population within an $80-\mathrm{km}$ radius of SRS. Within this radius, the total population was 713,500, based on 2000 census data.

Some of the collective doses resulting from SRS liquid releases are calculated for the populations served by the City of Savannah Industrial and Domestic Water Supply Plant, near Port Wentworth, Georgia, and by the Beaufort-Jasper Water Treatment Plant, near Beaufort, South Carolina. According to the treatment plant operators, the population served by the Port Wentworth facility during 2003 was approximately 11,000 persons, while the population served by the Beaufort-Jasper facility (including some residents of Hilton Head Island) was approximately 112,000 persons.

\section{River Flow Rate Data}

Although flow rates are recorded at a gauging station near River Mile 118.8 (U.S. Highway 301 bridge), these data are not used directly in dose calculations. This is because weekly river flow rates fluctuate widely (i.e., short-term dilution varies from week to week). Used instead are "effective" flow rates, which are calculated by dividing the total curies of tritium measured in transport at River Mile 118.8 by the

- $\quad$ average tritium concentration measured at River Mile 118.8 (to determine the maximally exposed individual dose)

- $\quad$ average tritium concentrations measured in finished drinking water at the two downriver treatment plants (to determine drinking water population doses)

For 2003, the River Mile 118.8 calculated (effective) flow rate of 11,138 cubic feet per second was used. This flow rate was over 100 percent more than the 2002 effective flow rate of 5,355 cubic feet per second because of substantially more rainfall during 2003 than in 2002. The effective flow rate was 14,792 cubic feet per second for the Beaufort-Jasper facility and 13,904 cubic feet per second for the Port Wentworth facility.

\section{Dose Calculation Results}

\section{Liquid Pathway}

\section{Liquid Release Source Terms}

The 2003 radioactive liquid release quantities used as source terms in SRS dose calculations are presented in chapter 3 and shown by radionuclide in table 5-1.

The total curies of tritium released is based on the measured tritium concentration at River Mile 118.8. This total $(7,450$ curies) includes contributions from Georgia Power Company's Vogtle Electric Generating Plant (1,900 curies) and from other sources (1,540 curies).

\section{Radionuclide Concentrations in Savannah River Water and Fish}

For use in dose determinations and model comparisons, the concentrations of tritium in Savannah River water and cesium-137 in Savannah River fish are measured at several locations along the river. The amounts of all other radionuclides released from SRS are so small that they usually cannot be detected in the Savannah River using conventional analytical techniques.

Radionuclide Concentrations in River Water and Treated Drinking Water The measured concentrations of tritium in the Savannah River near River Mile 118.8 and at the Beaufort-Jasper and Port Wentworth 
Table 5-1

2003 Radioactive Liquid Release Source Term and 12-Month Average Downriver Radionuclide Concentrations Compared to EPA's Drinking Water Maximum Contaminant Levels (MCL)

\begin{tabular}{|c|c|c|c|c|c|}
\hline \multirow[b]{2}{*}{ Nuclide } & \multirow[b]{2}{*}{$\begin{array}{l}\text { Curies } \\
\text { Released }\end{array}$} & \multicolumn{4}{|c|}{ 12-Month Average Concentration ( $\mathrm{pCi} / \mathrm{mL})$} \\
\hline & & $\begin{array}{l}\text { Below } \\
\text { SRS }^{a}\end{array}$ & $\begin{array}{l}\text { Beaufort- } \\
\text { Jasperb }\end{array}$ & $\begin{array}{l}\text { Port } \\
\text { Wentworthc }\end{array}$ & $\begin{array}{l}\text { EPA } \\
\text { MCL }\end{array}$ \\
\hline$H-3^{d}$ & $7.45 \mathrm{E}+03$ & 7.49E-01 & $5.64 \mathrm{E}-01$ & $6.00 \mathrm{E}-01$ & $2.00 \mathrm{E}+01$ \\
\hline Sr-90 & $9.67 \mathrm{E}-02$ & $9.72 \mathrm{E}-06$ & 7.32E-06 & $7.79 \mathrm{E}-06$ & 8.00E-03 \\
\hline I-129 & 7.82E-02 & 7.86E-06 & 5.92E-06 & $6.30 \mathrm{E}-06$ & $1.00 \mathrm{E}-03$ \\
\hline Cs-137 & $2.10 \mathrm{E}-01$ & 2.11E-05 & $1.59 \mathrm{E}-05$ & 1.69E-05 & 2.00E-01 \\
\hline U-234 & 6.97E-04 & 7.01E-08 & $5.28 \mathrm{E}-08$ & 5.61E-08 & $1.87 \mathrm{E}+02$ \\
\hline U-235 & 2.43E-05 & 2.44E-09 & $1.84 \mathrm{E}-09$ & $1.96 \mathrm{E}-09$ & $6.48 \mathrm{E}-01$ \\
\hline $\mathrm{U}-238$ & 7.05E-04 & 7.09E-08 & 5.34E-08 & $5.68 \mathrm{E}-08$ & $1.01 \mathrm{E}-02$ \\
\hline Pu-238 & $1.52 \mathrm{E}-04$ & $1.53 E-08$ & $1.15 \mathrm{E}-08$ & $1.22 \mathrm{E}-08$ & $1.50 \mathrm{E}-02$ \\
\hline Pu-239 & $8.48 \mathrm{E}-05$ & 8.52E-09 & $6.42 \mathrm{E}-09$ & $6.83 E-09$ & $1.50 \mathrm{E}-02$ \\
\hline Am-241 & $1.32 \mathrm{E}-04$ & 1.33E-08 & 9.99E-09 & $1.06 \mathrm{E}-08$ & $1.50 \mathrm{E}-02$ \\
\hline $\mathrm{Cm}-244$ & $1.05 E-04$ & $1.06 \mathrm{E}-08$ & 7.95E-09 & 8.46E-09 & $1.50 \mathrm{E}-02$ \\
\hline Alpha & 3.58E-02 & $3.60 \mathrm{E}-06$ & 2.71E-06 & $2.88 \mathrm{E}-06$ & $1.50 \mathrm{E}-02$ \\
\hline Beta & $1.46 \mathrm{E}-01$ & $1.47 \mathrm{E}-05$ & $1.11 \mathrm{E}-05$ & $1.18 \mathrm{E}-05$ & 8.00E-03 \\
\hline \multicolumn{2}{|c|}{ Sum of the Fractions of MCLs $=$} & 4.87E-02 & 3.67E-02 & $3.90 \mathrm{E}-02$ & \\
\hline
\end{tabular}

a Near Savannah River Mile 118.8, downriver of SRS at the U.S. Highway 301 bridge

b Beaufort-Jasper, South Carolina, drinking water

c Port Wentworth, Georgia, drinking water

d Curies released based on measured tritium concentrations at Savannah River Mile 118.8

water treatment facilities are shown in table 5-1, as are the calculated concentrations for the other released radionuclides.

The 12-month average tritium concentration measured in Savannah River water near River Mile 118.8 (0.749 $\mathrm{pCi} / \mathrm{mL}$ ) was about 25 percent less than the 2002 concentration of $1.01 \mathrm{pCi} / \mathrm{mL}$. This reduction occurred because of the more than 100-percent increase in the Savannah River flow rate in 2003 compared to 2002, which caused more dilution. The concentrations at the Beaufort-Jasper $(0.564 \mathrm{pCi} / \mathrm{mL})$ and Port Wentworth $(0.600 \mathrm{pCi} / \mathrm{mL})$ water treatment plants remained below the U.S. Environmental Protection Agency (EPA) maximum contaminant level (MCL) of $20 \mathrm{pCi} /$ $\mathrm{mL}$.

The MCL for each radionuclide released from SRS during 2003 is provided in table 5-1. The table indicates that all individual radionuclide concentrations at the two downriver community drinking water systems, as well as at River Mile 118.8, were below the MCLs.

Because more than one radionuclide is released from SRS, the sum of the fractions of the observed concen- tration of each radionuclide to its corresponding MCL must not exceed 1.0.

As shown in table 5-1, the sum of the fractions was 0.0390 at the Port Wentworth facility and 0.0367 at the Beaufort-Jasper facility. These are below the 1.0 sum-of-the-fractions requirement.

For 2003, the sum of the fractions at the River Mile 118.8 location was 0.0487 . This is provided here only for comparison because River Mile 118.8 is not a community water system location.

Radionuclide Concentrations in River Fish At SRS, an important dose pathway for the maximally exposed individual is from the consumption of fish.

Fish exhibit a high degree of bioaccumulation for certain elements. For the element cesium (including radioactive isotopes of cesium), the bioaccumulation factor for Savannah River fish is approximately 3,000. That is, the concentration of cesium found in fish flesh is about 3,000 times the concentration of cesium found in the water in which the fish live [Carlton et al, 1994].

Because of this high bioaccumulation factor, cesium-137 is more easily detected in fish flesh than in 
Table 5-2

Potential Dose to the Maximally Exposed Individual from SRS Liquid Releases in 2003

\begin{tabular}{llll}
\hline & $\begin{array}{l}\text { Committed } \\
\text { Dose (mrem) }\end{array}$ & $\begin{array}{l}\text { Applicable } \\
\text { Standard (mrem) }\end{array}$ & $\begin{array}{l}\text { Percent } \\
\text { of Standard }\end{array}$ \\
\cline { 2 - 3 } $\begin{array}{l}\text { Maximally Exposed Individual } \\
\text { (all liquid pathways) }\end{array}$ & 0.12 & $100^{\mathrm{a}}$ & 0.12 \\
$\begin{array}{l}\text { At Port Wentworth } \\
\text { (public water supply only) }\end{array}$ & $4^{\mathrm{b}}$ & 1.0 \\
$\begin{array}{l}\text { At Beaufort-Jasper } \\
\text { (public water supply only) }\end{array}$ & 0.04 & 1.0 \\
\hline $\begin{array}{l}\text { a All-pathway dose standard: } 100 \text { mrem per year (DOE Order 5400.5) } \\
\text { b Drinking water pathway standard: } 4 \text { mrem per year (DOE Order 5400.5) }\end{array}$ & $44^{\mathrm{b}}$ \\
\hline
\end{tabular}

river water. Therefore, the fish pathway dose from cesium-137 normally is based directly on the radioanalysis of the fish collected near Savannah River Mile 118.8, which is the assumed location of the hypothetical maximally exposed individual. However, in 2003 , the calculated concentration of cesium-137 in fish, which is based on measured effluent releases, was determined to be more than the actual measured concentrations in fish. To be conservative, the higher calculated cesium-137 concentrations were used in the 2003 dose determinations.

\section{Dose to the Maximally Exposed Individual}

As shown in table 5-2, the highest potential dose to the maximally exposed individual from liquid releases in 2003 was estimated at 0.12 mrem $(0.0012 \mathrm{mSv})$. This dose is 0.12 percent of DOE's 100-mrem all-pathway dose standard for annual exposure and is the same as the 2002 dose.

Approximately 55 percent of the dose to the maximally exposed individual resulted from the ingestion of cesium-137, mainly from the consumption of fish, and about 44 percent resulted from the ingestion (via drinking water) of tritium.

Drinking Water Pathway Persons downriver of SRS may receive a radiation dose by consuming drinking water that contains radioactivity as a result of liquid releases from the site. In 2003, tritium in downriver drinking water represented the majority of the dose (about 68 percent) received by persons at downriver water treatment plants.

The maximum potential drinking water doses during 2003 were determined to be about 0.04 mrem $(0.0004$ $\mathrm{mSv}$ ) for both the Beaufort-Jasper Water Treatment
Plant and the City of Savannah Industrial and Domestic Water Supply Plant (Port Wentworth). The 2003 maximum dose was about 33 percent less than the 2002 dose of 0.06 mrem $(0.0006 \mathrm{mSv})$, primarily because of the increase in Savannah River flow rate.

As shown in table 5-2, the maximum dose of 0.04 mrem $(0.0004 \mathrm{mSv})$ is 1.0 percent of the DOE standard of 4 mrem per year for public water supplies. For comparison, in table 5-1, the Port Wentworth sum of the fractions equated to 3.9 percent of the EPA MCLs. The difference between the DOE and EPA drinking water standards is explained in the "Potential Dose" section of appendix A.

\section{Collective (Population) Dose}

The collective drinking water consumption dose is calculated for the discrete population groups at Beaufort-Jasper and Port Wentworth. The collective dose from other pathways is calculated for a diffuse population that makes use of the Savannah River. However, this population cannot be described as being in a specific geographical location.

In 2003, the collective dose from SRS liquid releases was estimated at 2.9 person-rem (0.029 person-Sv). This was 25 percent less than the 2002 collective dose of 3.9 person-rem (0.039 person-Sv). Again, this reduction was caused by the substantial increase in the Savannah River flow rate.

\section{Potential Dose from Agricultural Irrigation}

Based on surveys of county agricultural extension agencies, there are no known large-scale uses of river water downstream of SRS for agricultural irrigation purposes. However, the potential for irrigation does 
exist, so potential doses from this pathway are calculated for information purposes only but are not included in calculations of the official maximally exposed individual or collective doses.

For 2003, a potential offsite dose of 0.08 mrem $(0.0008 \mathrm{mSv})$ to the maximally exposed individual and a collective dose of 5.9 person-rem ( 0.059 person-Sv) were estimated for this exposure pathway.

As in previous years, collective doses from agricultural irrigation were calculated for 1,000 acres of land devoted to each of four major food types-vegetation, leafy vegetation, milk, and meat. It is assumed that all the food produced on the 1,000-acre parcels is consumed by the $80-\mathrm{km}$ population of 713,500 .

\section{Air Pathway}

\section{Atmospheric Source Terms}

The 2003 radioactive atmospheric release quantities used as the source term in SRS dose calculations are presented in chapter 3 .

In 2003, krypton-85 accounted for about 55 percent of the radioactivity released to the atmosphere from SRS. Because krypton is an inert noble gas, it causes a relatively small amount of dose to humans (less than 1 percent of the maximally exposed individual dose in 2003).

Estimates of unmonitored diffuse and fugitive sources were included in the atmospheric source term, as required, for demonstrating compliance with NESHAP regulations.

\section{Atmospheric Concentrations}

Calculated radionuclide concentrations are used for dose determinations instead of measured concentrations. This is because most radionuclides released from SRS cannot be measured, using standard methods, in the air samples collected at the site perimeter and offsite locations. However, the concen- trations of tritium oxide at the site perimeter locations usually can be measured and are compared with calculated concentrations as a verification of the dose models, as shown in data tables on the CD accompanying this report.

\section{Dose to the Maximally Exposed Individual}

In 2003, the estimated dose to the maximally exposed individual was $0.07 \mathrm{mrem}(0.0007 \mathrm{mSv})$, which is 0.7 percent of the DOE Order 5400.5 ("Radiation Protection of the Public and the Environment") standard of 10 mrem per year. This dose was slightly higher than the 2002 dose of $0.06 \mathrm{mrem}(0.0006 \mathrm{mSv})$. This increase is attributed to higher iodine- 129 releases from $\mathrm{H}-\mathrm{Area}$, caused by increased operations in $\mathrm{H}$ Canyon during 2003. Table 5-3 compares the maximally exposed individual's dose with the DOE standard.

Tritium oxide releases accounted for 39 percent of the dose to the maximally exposed individual. Iodine-129 emissions accounted for 33 percent of the maximally exposed individual dose, and plutonium-239 emissions accounted for 12 percent. Nearly all the plutonium-239 releases were estimated to be from diffuse and fugitive sources (chapter 3 ).

The potential dose to the maximally exposed individual residing at the site boundary for each of the 16 major compass point directions around SRS can be found in the "Maps" appendix (figure 12) on the CD accompanying this report. For 2003, the due-north sector of the site was the location of the highest dose to the maximally exposed individual.

The major pathways contributing to the dose to the maximally exposed individual from atmospheric releases were inhalation ( 34 percent) and the consumption of vegetation (52 percent), cow milk (10 percent), and meat ( 3 percent).

Additional calculations of the dose to the maximally exposed individual were performed substituting goat

Table 5-3

Potential Dose to the Maximally Exposed Individual from SRS Atmospheric Releases in 2003

MAXDOSE-SR $\quad$ CAP88 (NESHAP)

$\begin{array}{lll}\text { Calculated dose (mrem) } & 0.07 & 0.05 \\ \text { Applicable standard (mrem) } & 10^{\mathrm{a}} & 10^{\mathrm{b}} \\ \text { Percent of standard } & 0.7 & 0.5\end{array}$

a DOE: DOE Order 5400.5, February 8, 1990

b EPA: (NESHAP) 40 CFR 61 Subpart H, December 15, 1989 
milk for the customary cow milk pathway. The potential dose using the goat milk pathway was estimated at $0.08 \mathrm{mrem}(0.0008 \mathrm{mSv})$.

\section{Collective (Population) Dose}

In 2003, the collective dose was estimated at 3.6 person-rem ( 0.036 person-Sv) -less than 0.01 percent of the collective dose received from natural sources of radiation (about 214,000 person-rem).

Tritium oxide releases accounted for 47 percent of the collective dose. The 2003 collective dose was about 20 percent more than the 2002 collective dose of 3.0 person-rem $(0.030$ person-Sv).

\section{NESHAP Compliance}

To demonstrate compliance with NESHAP regulations, maximally exposed individual and collective doses were calculated, and a percentage of dose contribution from each radionuclide was determined using the CAP88 computer code [EPA, 1999a]. The dose was estimated at $0.05 \mathrm{mrem}(0.0005 \mathrm{mSv})$, which is 0.5 percent of the 10-mrem-per-year EPA standard, as shown in table 5-3. Tritium oxide releases accounted for about 80 percent of this dose.

The CAP88-determined collective dose was estimated at 5.7 person-rem $(0.057$ person-Sv). Tritium oxide releases also accounted for about 82 percent of this dose.

The CAP88 code estimates a higher dose for tritium oxide than do the MAXDOSE-SR and POPDOSE-SR codes, which are used for showing compliance with DOE environmental orders [SRS EM Program, 2001]. Most of the differences occur in the tritium dose estimated from food consumption. The major cause of this difference is the CAP88 code's use of 100-percent equilibrium between tritium in air moisture and tritium in food moisture, whereas the MAXDOSE-SR and POPDOSE-SR codes use 50-percent equilibrium values, as recommended by the Nuclear Regulatory Commission [NRC, 1977]. A site-specific study indicated that the 50-percent value is correct for the atmospheric conditions at SRS [Hamby and Bauer, 1994].

Because tritium oxide dominates the doses determined using the CAP88 code, and because the CAP88 code is limited to a single, center-of-site release location, other radionuclides (such as plutonium-239) are less important-on a percentage-of-dose basis-for the CAP88 doses than for the MAXDOSE-SR and POPDOSE-SR doses.

\section{All-Pathway Dose}

To demonstrate compliance with the DOE Order 5400.5 all-pathway dose standard of $100 \mathrm{mrem}$ per year (1.0 mSv per year), SRS conservatively combines the maximally exposed individual airborne pathway and liquid pathway dose estimates, even though the two doses are calculated for hypothetical individuals residing at different geographic locations.

For 2003, the potential maximally exposed individual all-pathway dose was $0.19 \mathrm{mrem}(0.0019 \mathrm{mSv}) — 0.07$ mrem from airborne pathway plus $0.12 \mathrm{mrem}$ from liquid pathway - and is 0.19 percent of the 100-mrem-per-year DOE dose standard. This dose is slightly more than the 2002 all-pathway dose of 0.18 mrem $(0.0018 \mathrm{mSv})$.

Figure 5-1 shows a 10-year history of SRS's all-pathway doses (airborne pathway plus liquid pathway doses to the maximally exposed individual).

\section{Sportsman Dose}

DOE Order 5400.5 specifies radiation dose standards for individual members of the public. The dose standard of 100 mrem per year includes doses a person receives from routine DOE operations through all exposure pathways. Nontypical exposure pathways, not included in the standard calculations of the doses to the maximally exposed individual, are considered and quantified separately. This is because they apply to low-probability scenarios, such as consumption of fish caught exclusively from the mouths of SRS streams, or to unique scenarios, such as volunteer deer hunters.

In addition to deer, hog, and fish consumption, the following exposure pathways were considered for an offsite hunter and an offsite fisherman - both on Creek Plantation, a privately owned portion of the Savannah River Swamp, which was contaminated by SRS operations in the 1960s (chapter 4):

- External exposure to contaminated soil

- Incidental ingestion of contaminated soil

- Incidental inhalation of resuspended contaminated soil

\section{Onsite Hunter Dose}

Deer and Hog Consumption Pathway The estimated dose from consumption of the harvested deer or hog meat is determined for every onsite hunter.

During 2003, the maximum potential dose that could have been received by an actual onsite hunter was 


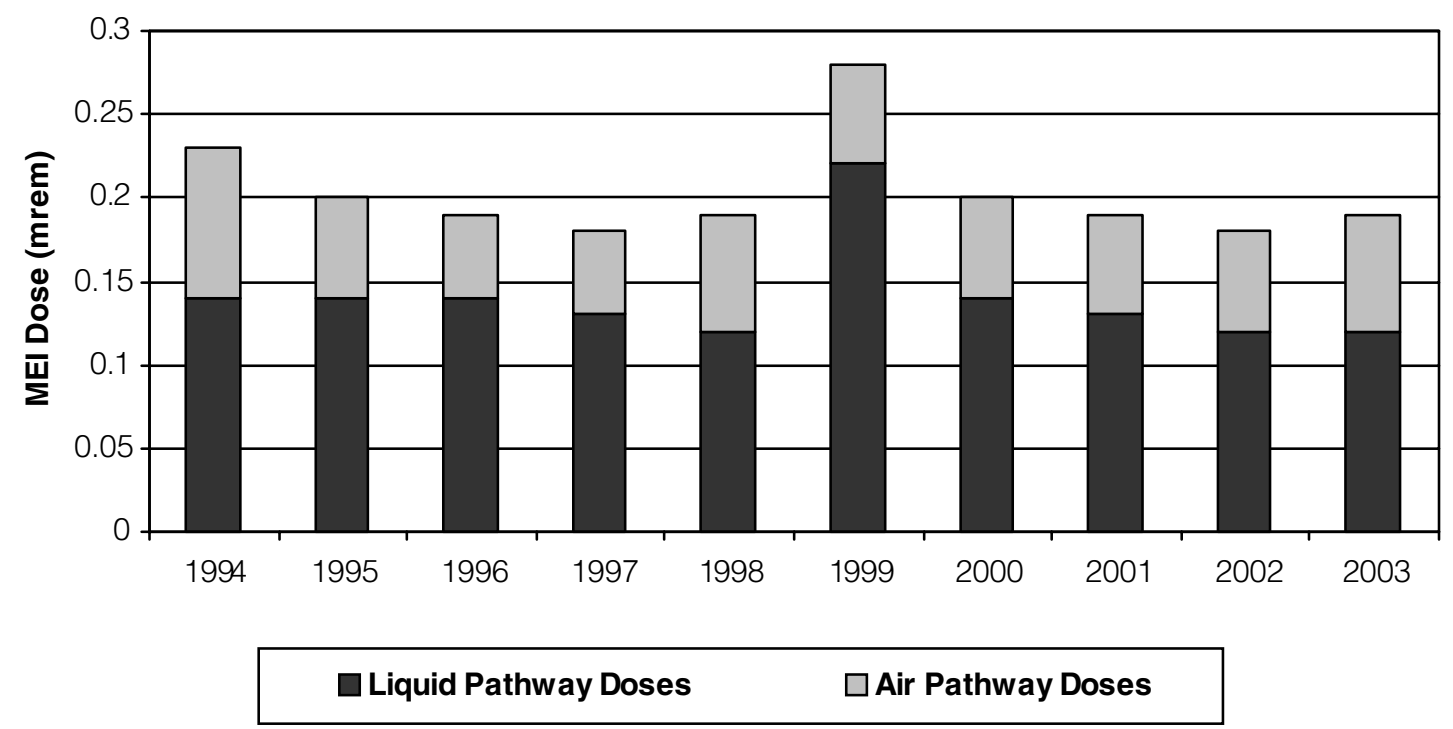

Figure 5-1 Ten-Year History of SRS Maximum Potential All-Pathway Doses

estimated at 15.6 mrem $(0.156 \mathrm{mSv})$, or 15.6 percent of DOE's 100-mrem all-pathway dose standard (table 5-4). This dose was determined for a hunter who in fact harvested one deer during the 2003 hunts. The hunter-dose calculation is based on the conservative assumption that this hunter individually consumed the entire edible portion-approximately $54.4 \mathrm{~kg}$ (120 pounds) — of the deer he harvested from SRS.

\section{Offsite Hunter Dose}

Deer and Hog Consumption Pathway The deer and hog consumption pathway considered was for hypothetical offsite individuals whose entire intake of meat during the year was either deer or hog meat. It was assumed that these individuals harvested deer or hogs that had resided on SRS, but then moved off site.

Based on these low-probability assumptions and on the measured average concentration of cesium-137 in all deer $(1.3 \mathrm{pCi} / \mathrm{g})$ and hogs $(1.2 \mathrm{pCi} / \mathrm{g})$ harvested from SRS during 2003, the potential maximum doses from this pathway were estimated at $1.2 \mathrm{mrem}(0.012$ $\mathrm{mSv})$ for the deer hunter and at $0.81 \mathrm{mrem}(0.0081$ $\mathrm{mSv}$ ) for the hog hunter.

A background cesium-137 concentration of $1 \mathrm{pCi} / \mathrm{g}$ is subtracted from the onsite average concentrations before calculating the doses. The background concentration is based on previous analyses of deer harvested $80 \mathrm{~km}$ from SRS (table 33, SRS Environmental Data for 1994, WSRC-TR-95-077).

\section{Savannah River Swamp Hunter Soil Exposure} Pathway The potential dose to a recreational hunter exposed to SRS legacy contamination in Savannah River Swamp soil on the privately owned Creek Plantation in 2003 was estimated using the RESRAD dosimetry code (DOE Order 5400.5). It was assumed that this recreational sportsman hunted for 120 hours during the year ( 8 hours per day for 15 days) at the location of maximum radionuclide contamination.

Using the worst-case radionuclide concentrations from the most recent comprehensive survey-conducted in 2000 - the potential dose to a hunter from a combination of (1) external exposure to the contaminated soil, (2) incidental ingestion of the soil, and (3) incidental inhalation of resuspended soil was estimated to be 4.4 mrem $(0.044 \mathrm{mSv})$.

As shown in table 5-4, the offsite deer consumption pathway and the Savannah River Swamp hunter soil exposure pathway were conservatively added together to obtain a total offsite hunter dose of 5.6 mrem $(0.056$ $\mathrm{mSv}$ ). This potential dose is 5.6 percent of the DOE 100-mrem all-pathway dose standard.

\section{Offsite Fisherman Dose}

Creek Mouth Fish Consumption Pathway For 2003, radioanalyses were conducted of fish taken from the mouths of five SRS streams, and the subsequent estimated doses were calculated. 
Table 5-4

2003 Maximum Potential All-Pathway and Sportsman Doses Compared to the DOE All-Pathway Dose Standard

\begin{tabular}{|c|c|c|c|c|}
\hline & & $\begin{array}{l}\text { Committed } \\
\text { Dose (mrem) }\end{array}$ & $\begin{array}{l}\text { Applicable } \\
\text { Standard (mrem) }^{a}\end{array}$ & $\begin{array}{l}\text { Percent } \\
\text { of Standard }\end{array}$ \\
\hline \multicolumn{5}{|c|}{ Maximally Exposed Individual Dose } \\
\hline & $\begin{array}{l}\text { All-Pathway } \\
\text { (Liquid Plus Airborne Pathway) }\end{array}$ & 0.19 & 100 & 0.19 \\
\hline \multicolumn{5}{|c|}{ Sportsman Doses } \\
\hline & Onsite Hunter & 15.6 & 100 & 15.6 \\
\hline & Creek Mouth Fisherman'b & 0.58 & 100 & 0.58 \\
\hline \multicolumn{5}{|c|}{ Savannah River Swamp Hunter } \\
\hline & Offsite Deer Consumption & 1.2 & & \\
\hline & Offsite Hog Consumption & 0.81 & & \\
\hline & Soil Exposure ${ }^{c}$ & 4.4 & & \\
\hline & Total Offsite Deer Hunter Dose & 5.6 & 100 & 5.6 \\
\hline \multicolumn{5}{|c|}{ Savannah River Swamp Fisherman } \\
\hline & Steel Creek Fish Consumption & 0.12 & & \\
\hline & Soil Exposured & 0.54 & & \\
\hline & Total Offsite Fisherman Dose & 0.66 & 100 & 0.66 \\
\hline \multicolumn{5}{|c|}{$\begin{array}{l}\text { All-pathway dose standard: } 100 \text { mrem per year (DOE Order } 5400.5 \text { ) } \\
\text { In } 2003 \text {, the maximum fisherman dose was caused by the consumption of bass from the mouth of Four Mile Creek. } \\
\text { Includes the dose from a combination of external exposure to-and incidental ingestion and inhalation of-the } \\
\text { worst-case Savannah River Swamp soil } \\
\text { Includes the dose from a combination of external exposure to-and incidental ingestion and inhalation of-Savannah } \\
\text { River Swamp soil near the mouth of Steel Creek }\end{array}$} \\
\hline
\end{tabular}

As shown in table 5-4, the maximum potential dose from this pathway was estimated at $0.58 \mathrm{mrem}(0.0058$ $\mathrm{mSv}$ ) from the consumption of bass collected at the mouth of Four Mile Creek. This hypothetical dose is based on the low-probability scenario that, during 2003, a fisherman consumed $19 \mathrm{~kg}$ of bass caught exclusively from the mouth of Four Mile Creek. About 94 percent of this potential dose was from cesium-137.

Savannah River Swamp Fisherman Soil Exposure Pathway The potential dose to a recreational fisherman exposed to SRS legacy contamination in Savannah River Swamp soil on the privately owned Creek Plantation in 2003 was estimated using the RESRAD dosimetry code. It was assumed that this recreational sportsman fished on the South Carolina bank of the Savannah River near the mouth of Steel Creek for 250 hours during the year.

During the comprehensive survey of the Savannah River Swamp conducted in 2000, the location on
Creek Plantation that was closest to the South Carolina bank of the Savannah River and the mouth of Steel Creek was on trail 1 , at a distance of 0 feet from the Savannah River.

Using the radionuclide concentrations measured at this location, the potential dose to a fisherman from a combination of 1) external exposure to the contaminated soil, 2) incidental ingestion of the soil, and 3) incidental inhalation of resuspended soil was estimated to be 0.54 mrem $(0.0054 \mathrm{mSv})$.

As shown in table 5-4, the maximum Steel Creek mouth fish consumption dose $(0.12 \mathrm{mrem})$ and the Savannah River Swamp fisherman soil exposure pathway were conservatively added together to obtain a total offsite creek mouth fisherman dose of 0.66 mrem $(0.0066 \mathrm{mSv})$. This potential dose is 0.66 percent of the DOE 100-mrem all-pathway dose standard. 


\section{Potential Risk from Consumption of SRS Creek Mouth Fish}

During 1991 and 1992, in response to a U.S. House of Representatives Appropriations Committee request for a plan to evaluate risk to the public from fish collected from the Savannah River, SRS developed-in conjunction with EPA, the Georgia Department of Natural Resources, and the South Carolina Department of Health and Environmental Control—-the Westinghouse Savannah River Company/Environmental Monitoring Section Fish Monitoring Plan, which is summarized in SRS EM Program, 2001. Among the reporting requirements of this plan are (1) assessing radiological risk from the consumption of Savannah River fish and (2) presenting a summary of the results in the annual SRS Environmental Report.

Risk Comparisons For 2003, the maximum potential radiation doses and lifetime risks from the consumption of SRS creek mouth fish for 1-year, 30-year, and 50-year exposure durations are shown in table 5-5 and are compared to the radiation risks associated with the DOE Order 5400.5 all-pathway dose standard of 100 mrem $(1.0 \mathrm{mSv})$ per year.

The potential risks were estimated using the cancer morbidity risk coefficients from Federal Guidance Report No. 13 [EPA, 1999b].

For 2003, the maximum recreational fisherman dose was caused by the consumption of bass collected at the mouth of Four Mile Creek.
Figure 5-2 shows a 10-year history of the annual potential radiation doses from consumption of Savannah River fish. No apparent trends can be discerned from these data. This is because there is large variability in the annual strontium-90 and cesium-137 concentrations measured in fish from the same location due to differences in

- the size of the fish collected each year

- their mobility and location within the stream mouth from which they are collected

- the time of year they are collected

- variability in the amount of strontium-90 and cesium-137 available in the water and sediments at the site stream mouths - caused by annual changes in stream flow rates (turbulence) and water chemistry

As indicated in table 5-5, the 50-year maximum potential lifetime risk from consumption of SRS creek mouth fish was 2.4E-05, which is below the 50-year risk (3.7E-03) associated with the 100-mrem-per-year dose standard.

According to EPA practice, if a potential lifetime risk is calculated to be less than 1.0E-06 (i.e., one additional case of cancer over what would be expected in a group of 1,000,000 people), then the risk is considered minimal and the corresponding contaminant concentrations are considered negligible. If a calculated risk is more than 1.0E-04 (one additional case of cancer in a population of 10,000), then some form of corrective

Table 5-5

Potential Lifetime Risks from the Consumption of Savannah River Fish Compared to Dose Standards

\begin{tabular}{|c|c|c|c|}
\hline & & $\begin{array}{l}\text { Committed } \\
\text { Dose (mrem) }\end{array}$ & $\begin{array}{l}\text { Potential Risk } \\
\text { (unitless) }\end{array}$ \\
\hline \multicolumn{4}{|c|}{2003 Savannah River Fish } \\
\hline & 1-Year Exposure & 0.58 & 4.4E-07 \\
\hline & 30-Year Exposure & 17.4 & 1.3E-05 \\
\hline & 50-Year Exposure & 29.0 & $2.4 \mathrm{E}-05$ \\
\hline \multicolumn{4}{|c|}{ Dose Standard } \\
\hline \multicolumn{4}{|c|}{ 100-mrem/year All Pathway } \\
\hline & 1-Year Exposure & 100 & 7.3E-05 \\
\hline & 30-Year Exposure & 3,000 & $2.2 \mathrm{E}-03$ \\
\hline & 50-Year Exposure & 5,000 & 3.7E-03 \\
\hline a & \multicolumn{3}{|c|}{$\begin{array}{l}\text { It should be noted that all radiological risk factors are based on observed and documented health effects to actual people } \\
\text { who have received high doses (more than } 10,000 \text { mrem) of radiation, such as the Japanese atomic bomb survivors. } \\
\text { Radiological risks at low doses (less than 10,000 mrem) are theoretical and are estimated by extrapolating the observed } \\
\text { health effects at high doses to the low-dose region by using a linear, no-threshold model. However, cancer and other } \\
\text { health effects have not been observed consistently at low radiation doses because the health risks either do not exist or } \\
\text { are so low that they are undetectable by current scientific methods. }\end{array}$} \\
\hline
\end{tabular}




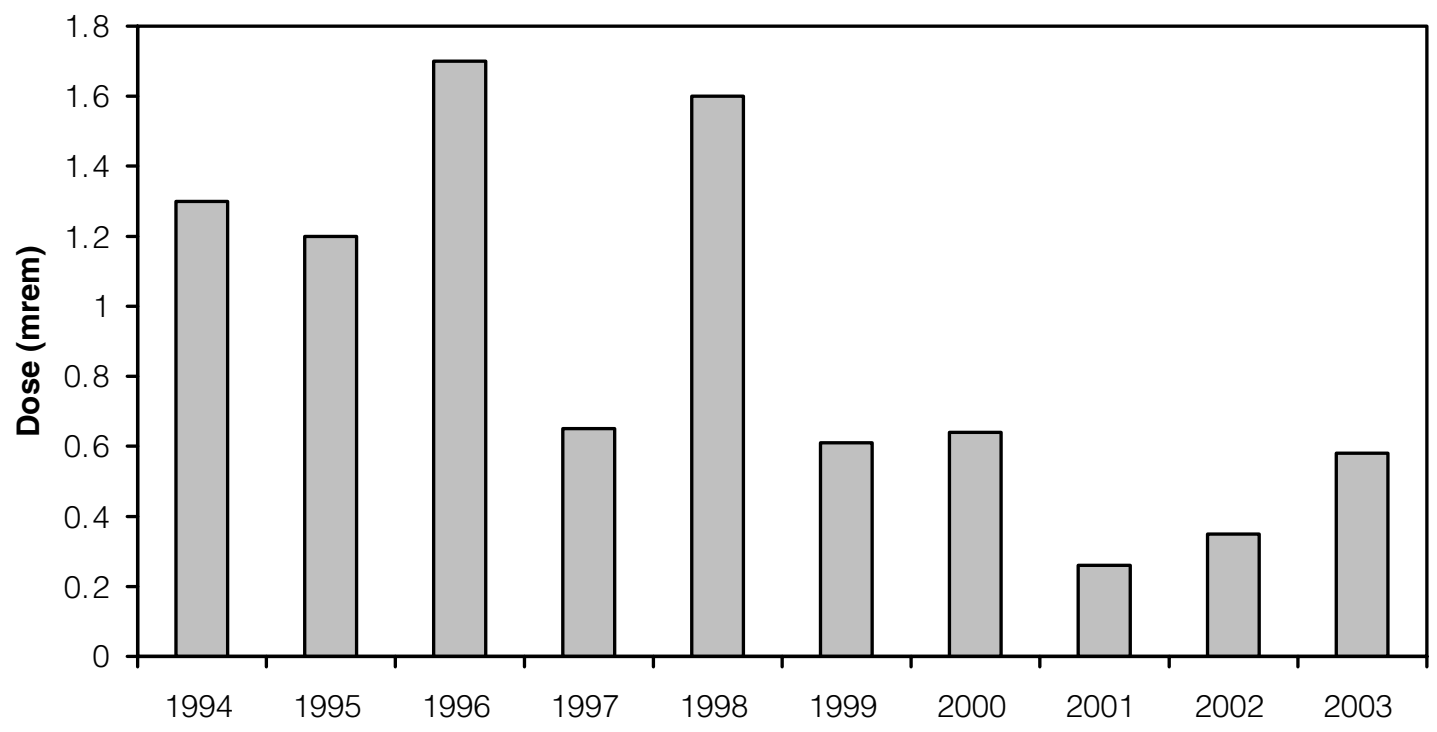

Figure 5-2 Ten-Year History of Savannah River Site Creek Mouth Fisherman's Dose

action or remediation usually is required. However, if a calculated risk falls between 1.0E-04 and 1.0E-06, which is the case with the maximum potential lifetime risks from the consumption of Savannah River fish, then the risks are considered acceptable if they are kept as low as reasonably achievable (ALARA).

At SRS, the following programs are in place to ensure that the potential risk from site radioactive liquid effluents (and, therefore, from consumption of Savannah River fish) is kept ALARA:

- radiological liquid effluent monitoring program (chapter 3)

- radiological environmental surveillance program (chapter 4)

- environmental ALARA program [SRS EM Program, 2001]

\section{Dose to Aquatic and Terrestrial Animal Organisms}

DOE Order 5400.5 establishes an interim dose standard for protection of native aquatic animal organisms. The absorbed dose limit to these organisms is $1.0 \mathrm{rad}$ per day (0.01 Gy per day) from exposure to radioactive material in liquid effluents released to natural waterways.

\section{Initial Screening of Biota Doses Using DOE Biota Concentration Guides}

For 2003, a screening of biota doses at SRS was performed using the RESRAD-Biota model, which is based on the DOE standard entitled A Graded Approach for Evaluating Radiation Doses to Aquatic and Terrestrial Biota [DOE, 2002].

The aquatic systems evaluation includes exposures to primary (herbivores) and secondary (predators) aquatic animals, and the BCGs are based on the 1.0-rad-per-day dose limit. Aquatic plants are not considered.

The terrestrial systems evaluation includes exposures to terrestrial plants and animals and is based on a 10-rad-per-day dose limit for plants and a 0.1-rad-per-day dose limit for animals. For the aquatic systems evaluation portion of the BCGs, an initial screening was performed using maximum radionuclide concentration data for the 12 EMS stream sampling locations from which co-located water and sediment samples are collected. An exception to this was made for sample location FM-2B (located on Four Mile Creek between F-Area and H-Area) because of its historically high cesium and tritium concentration levels. This location was included in the initial screening even though no co-located sediment sample is collected there.

The combined water-plus-sediment BCG sum of the ratios was used for the aquatic systems evaluation. A sum of the ratios less than one indicates the sampling site has passed the initial pathway screen.

For the terrestrial systems evaluation portion of the BCGs, an initial screening was performed using concentration data from the five EMS onsite radiologi- 
cal soil sampling locations. Only one soil sample per year is collected from each location.

For 2003, stream sampling locations R-1 (located adjacent to R-Reactor near the center of SRS),

FM-A7, FM-2, and FM-2B failed the initial aquatic systems screen. All other locations, including the five soil sampling locations, passed.
For the four locations that failed, an additional assessment was performed using annual average radionuclide concentrations measured in the water and sediment samples. All locations passed this secondary screen (the sum of the ratios of each was less than 1.0). 



\title{
Chapter 6
}

\section{Groundwater}

\author{
Dan Wells \\ Environmental Services Section
}

Bob Hiergesell

Waste Processing Technology

$\mathrm{G}$

ROUNDWATER protection at the Savannah River Site (SRS) has evolved into a program with the following primary components:

- $\quad$ Protect groundwater by good practices in managing chemicals and work.

- Monitor groundwater to identify areas of contamination.

- Remediate contamination as needed.

- Use groundwater wisely to conserve.

SRS operations have contaminated groundwater around certain waste disposal facilities. Extensive monitoring and remediation programs are tracking and cleaning up the contamination. Remediation includes (1) the closing of waste sites to reduce the migration of contaminants into groundwater and (2) the active treatment of contaminated water.

No offsite wells have been contaminated by the migration of SRS groundwater.

This chapter describes SRS's groundwater environment and the programs in place for investigating, monitoring, remediating, and using the groundwater.

\section{Groundwater at SRS}

SRS is underlain by sediment of the Atlantic Coastal Plain. The Atlantic Coastal Plain consists of a southeast-dipping wedge of unconsolidated sediment that extends from its contact with the Piedmont Province at the Fall Line to the edge of the continental shelf. The sediment ranges from Late Cretaceous to Miocene in age and comprises layers of sand, muddy sand, and clay with subordinate calcareous sediments. It rests on crystalline and sedimentary basement rock.

Water flows easily through the sand layers but is retarded by less permeable clay beds, creating a complex system of aquifers. Operations during the life of SRS have resulted in contamination migrating into groundwater at various site locations, predominantly in the central areas of the site. The ongoing movement of water into the ground, through the aquifer system, and then into streams and lakes-or even into deeper aquifers - continues to carry contamination along with it, resulting in spreading plumes.

The hydrostratigraphy of SRS has been subject to several classifications. The hydrostratigraphic classification established in Aadland et al., 1995, and in Smits et al., 1996, is widely used at SRS and is regarded as the current SRS standard. This system is consistent with the one used by the U.S. Geological Survey (USGS) in regional studies that include the area surrounding SRS [Clarke and West, 1997]. Figure 6-1 is a chart that indicates the relative position of hydrostratigraphic units and relates hydrostratigraphic units to corresponding lithologic units at SRS and to the geologic time scale. This chart was modified from Aadland et al., 1995, and Fallaw and Price, 1995

The hydrostratigraphic units of primary interest beneath SRS are part of the Southeastern Coastal Plain Hydrogeologic Province. Within this sequence of aquifers and confining units are two principal subcategories, the overlying Floridan Aquifer System and the underlying Dublin-Midville Aquifer System. These systems are separated from one another by the Meyers Branch Confining System. In turn, each of the systems is subdivided into two aquifers, which are separated by a confining unit.

In the central to southern portion of SRS, the Floridan Aquifer System is divided into the overlying Upper Three Runs Aquifer and the underlying Gordon Aquifer, which are separated by the Gordon Confining Unit. North of Upper Three Runs Creek, these units are collectively referred to as the Steed Pond Aquifer, in which the Upper Three Runs Aquifer is called the M-Area Aquifer zone, the Gordon Aquifer is referred to as the Lost Lake Aquifer zone, and the aquitard that separates them is referred to as the Green Clay confining zone [Aadland et al., 1995]. The Upper Three Runs Aquifer/Steed Pond Aquifer is the hydrostratigraphic unit within which the water table usually occurs at SRS; hence, it is informally referred to as the "water table" aquifer. 


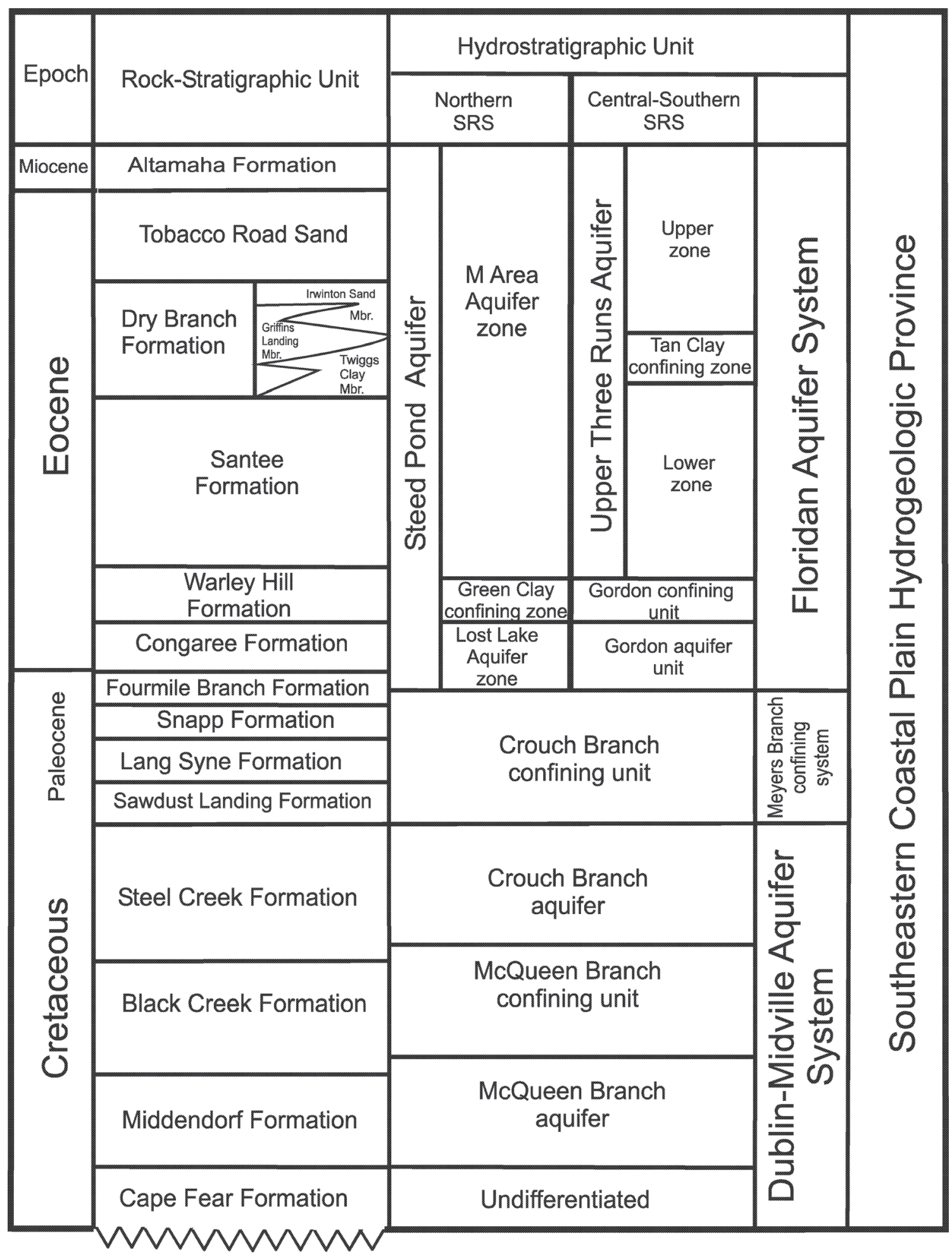

Paleozoic Crystalline Basement Rock or Triassic

Piedmont Hydrogeologic Province

Newark Supergroup

Figure 6-1 Hydrostratigraphic Units at SRS. 
The Dublin-Midville Aquifer System is divided into the overlying Crouch Branch Aquifer and the underlying McQueen Branch Aquifer, which are separated by the McQueen Branch Confining Unit. The Crouch Branch Aquifer and McQueen Branch Aquifer are names that originated at SRS [Aadland et al., 1995]. These units are equivalent to the Dublin Aquifer and the Midville Aquifer, which are names originating with the USGS [Clarke and West, 1997].

Figure 6-2 is a three-dimensional block diagram of the hydrogeologic units at SRS and the generalized groundwater flow patterns within those units. These units are from shallowest to deepest: the Upper Three Runs/Steed Pond Aquifer (or water table aquifer), the Gordon/Lost Lake Aquifer, the Crouch Branch Aquifer, and the McQueen Branch Aquifer.

Groundwater recharge is a result of the infiltration of precipitation at the land surface; the precipitation moves vertically downward through the unsaturated zone to the water table. Upon entering the saturated zone at the water table, water moves predominantly in a horizontal direction toward local discharge zones along the headwaters and midsections of streams, while some of the water moves into successively deeper aquifers. The water lost to successively deeper aquifers also migrates laterally within those units toward the more distant regional discharge zones. These typically are located along the major streams and rivers in the area, such as the Savannah River. Groundwater movement within these units is extremely slow when compared to surface water flow rates. Groundwater velocities also are quite different between aquitards and aquifers, ranging at SRS from several inches to several feet per year in aquitards and from tens to hundreds of feet per year in aquifers.

Monitoring wells are used extensively at SRS to assess the effect of site activities on groundwater quality. Most of the wells monitor the upper groundwater zone, although wells in lower zones are present at the sites with the larger groundwater contamination plumes. Groundwater in some areas contains one or more constituents at or above the levels of the DWS of the U.S. Environmental Protection Agency (EPA). These areas can be seen in figure 14 of the "SRS Maps" appendix on the CD accompanying this report.

\section{Groundwater Protection Program at SRS}

The SRS groundwater program was audited by both the U.S. Department of Energy (DOE) and WSRC during 2000 and 2001. Findings of these assessments have resulted in an ongoing evaluation of the goals and priorities of the site groundwater program. It has been determined that a groundwater protection program designed to meet federal and state laws and regulations, DOE orders, and site policies and procedures should contain the following elements:

- investigating site groundwater

- using site groundwater

- $\quad$ protecting site groundwater

- monitoring site groundwater

- remediating contaminated site groundwater

SRS identified specific program goals in each of these areas to maintain its commitment to a groundwater program that protects human health and the environment. Groundwater monitoring is a key tool used in each of the first four elements, and monitoring results form the basis for evaluations that are reported to site stakeholders.

\section{Investigating SRS Groundwater}

An extensive program is in place at SRS to acquire new data and information on the groundwater system. This program is multifaceted and is conducted across departmental boundaries at the site because of the different charters and mandates of these organizations. Investigations include both the collection and analysis of data to understand groundwater conditions on regional and local scales at SRS. Research efforts at the site generally are conducted to obtain a better understanding of subsurface processes and mechanisms or to define new approaches to subsurface remediation.

Investigative efforts focus on the collection and analysis of data to characterize the groundwater flow system. Characterization efforts at SRS include the following activities:

- the collection of geologic core material and the performing of seismic profiles to better delineate subsurface structural features

- the installation of wells to allow the periodic collection of both water levels and groundwater samples at strategic locations

- the development of water table and potentiometric maps to delineate the direction of groundwater movement in the subsurface

- the performance of various types of tests to obtain in situ estimates of hydraulic parameters needed to estimate groundwater velocities 


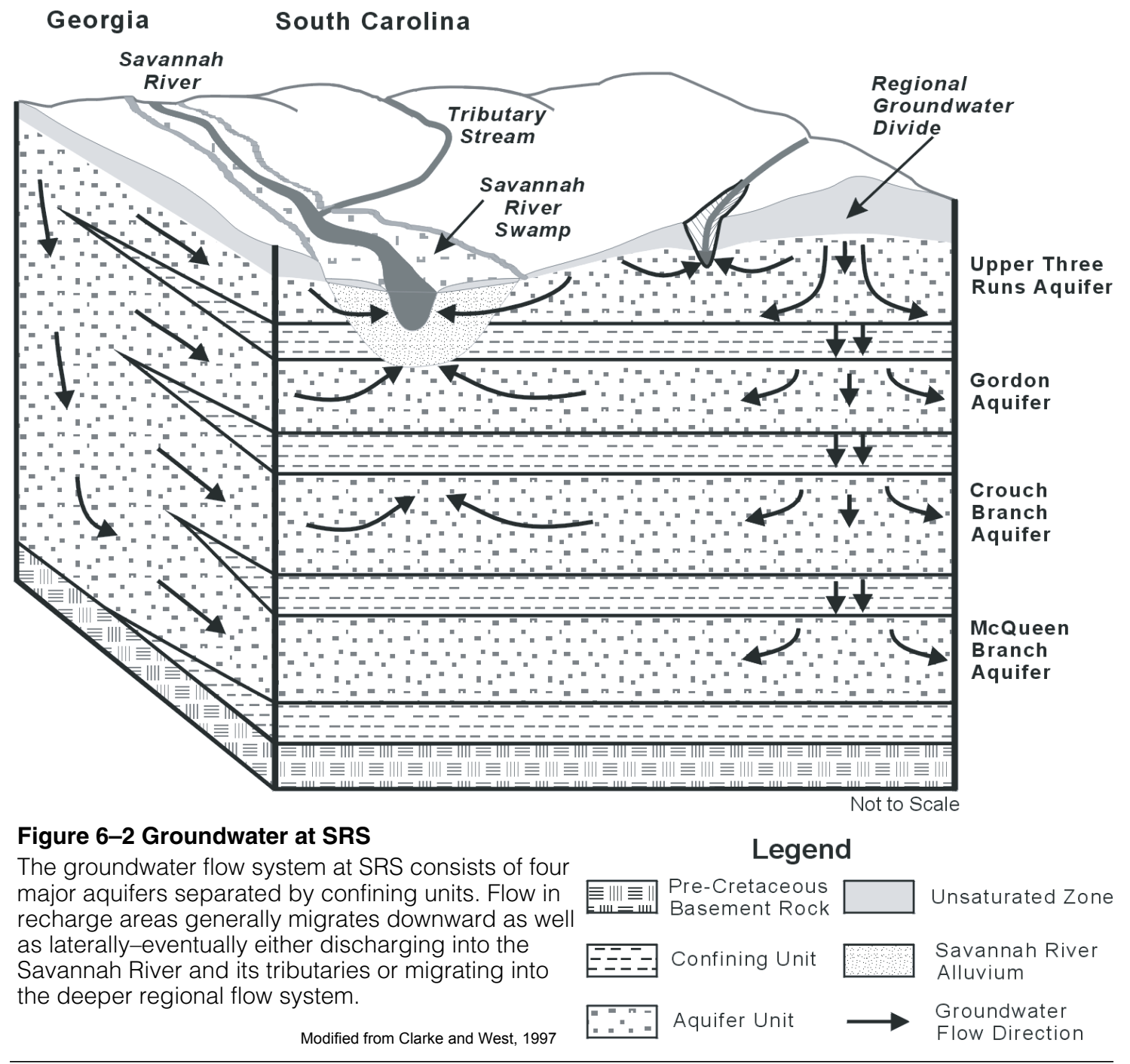

Analysis of data on the regional scale is needed to provide a broad understanding of groundwater movement patterns at SRS that can be used as a framework to better understand the migration of contaminants at the local scale near individual waste units. Surface water flow characteristics also are defined at the site on the regional scale and are significant to risk analyses because perennial streams are the receptors of groundwater discharge - some of which contains contaminants from SRS waste units. Because the site boundary does not represent a groundwater boundary, regional studies are helpful in understanding the movement of groundwater both onto the site from the surrounding area and vice versa.

The collection and analysis of data describing subsurface hydrogeologic conditions at or near individual waste units is needed to design effective remediation systems. Characterization embraces both traditional and innovative technologies to accomplish this goal. The installation of monitoring wells and piezometers is a traditional investigative method to allow the collection of (1) water levels, which are used to define flow directions, and (2) groundwater samples, which are analyzed to monitor contaminant plume migration within the groundwater flow system. Electric logs acquired during well installation are used to delineate the subsurface hydrostratigraphy. Examples of newer technologies include the use of

- $\quad$ direct-push technology, such as the cone penetrometer, to collect one-time groundwater samples at investigation sites and to help establish hydrostratigraphic contacts

- the "rotosonic" method for bore holes to collect core and install wells 
Numerical models have been used extensively as an analytical tool at SRS for both regional and local-scale investigations. Models have been utilized for a variety of reasons, but primarily to (1) define the regional groundwater movement patterns at SRS and the surrounding areas, (2) enhance the understanding of contaminant migration in the subsurface, and (3) support the design of remediation systems. At SRS, major groundwater modeling efforts have focused on A/M-Area, F-Area, H-Area, the Burial Ground Complex, and several of the reactor areas where the most extensive subsurface contamination is known to exist.

Research on groundwater issues is conducted at SRS to obtain a better understanding of subsurface mechanisms, such as (1) the interaction of contaminants with the porous media matrix, and (2) the factors that impact the rate of migration of contaminants within the groundwater flow system. Research to address relevant issues often is conducted through cooperative studies with investigators at various public universities and private companies, while other efforts are conducted exclusively by SRS employees.

\section{Using SRS Groundwater}

SRS derives its own drinking and production water supply from groundwater. The site ranks as South Carolina's largest self-supplied industrial consumer of groundwater, utilizing approximately 5.3 million gallons per day. SRS domestic and process water systems are supplied from a network of approximately 40 site wells in widely scattered locations across the site, of which eight supply the primary drinking water system for the site. Treated well water is supplied to the larger site facilities by the A-Area, D-Area, and $\mathrm{K}$-Area domestic water systems. Each system has wells, a treatment plant, elevated storage tanks, and distribution piping. The wells range in capacity from 200 to 1,500 gallons per minute.

These three systems supply an average of 1.1 million gallons per day of domestic water to customers in these areas. The domestic water systems supply site drinking fountains, lunchrooms, restrooms, and showering facilities with water meeting state and federal drinking water quality standards. Process water is used for equipment cooling and facility washdown water, and as makeup water for site cooling towers and production processes.

The South Carolina Department of Health and Environmental Control (SCDHEC) periodically samples the large- and small-system wells for Safe Drinking Water Act contaminants. An unscheduled biannual SCDHEC sanitary survey also is performed.
In 1983, SRS began reporting its water usage annually to the South Carolina Water Resources Commission (and later to SCDHEC). Since that time, the amount of groundwater pumped on site has dropped by more than 50 percent - from 10.8 million gallons per day during 1983-1986 to 5.3 million gallons per day during 1997-2000. The majority of this decrease is attributable to the consolidation of site domestic water systems, which was completed in 1997. Thirteen separate systems, each with its own supply wells, were consolidated into three systems located in A-Area, D-Area, and K-Area. Site facility shutdowns and reductions in population also were contributing factors. The amount of groundwater pumped at SRS has had only localized effects on water levels in the Cretaceous aquifers, and it is unlikely that water usage at the site ever will cause drawdown problems that could impact surrounding communities.

The process water systems in A-Area, F-Area, H-Area, K-Area, L-Area, S-Area, and TNX-Area meet site demands for boiler feedwater, equipment cooling water, facility washdown water, and makeup water for cooling towers, fire storage tanks, chilled-water-piping loops, and site test facilities. These systems are supplied from dedicated process water wells ranging in capacity from 100 to 1,500 gallons per minute. In $\mathrm{K}$-Area, the process water system is supplied from the domestic water wells. At some locations, the process water wells pump to ground-level storage tanks, where the water is treated for corrosion control. At other locations, the wells directly pressurize the process water distribution piping system without supplemental treatment.

The site groundwater protection program integrates information learned about the properties of SRS aquifers with site demand for drinking and process water. SRS ensures a high level of drinking water supply protection by performing (1) monitoring above and beyond SCDHEC monitoring and (2) periodic evaluations of production wells. Additional protection will be realized under a site wellhead protection program that meets the requirements of the South Carolina Source Water Assessment Program described below.

\section{Protecting SRS Groundwater}

SRS is committed to protecting the groundwater resource beneath the site. A variety of activities contribute to this goal, including

- construction, waste management, and monitoring efforts to prevent or control sources of groundwater contamination 
- $\quad$ monitoring programs (both groundwater and surface water) to detect contamination

- $\quad$ a strong groundwater cleanup program through the Soil and Groundwater Closure Projects Department

Monitoring around waste disposal sites and operating facilities provides the best means to detect and track groundwater contamination. To ensure that no unknown contamination poses a risk, SRS depends on a sitewide groundwater monitoring and protection effort - the site Groundwater Surveillance Monitoring Program (GSMP). This new program is an upgraded replacement of the site screening program.

One goal of the GSMP is to protect potential offsite receptors from contamination by detecting contamination in time to apply appropriate corrective actions. SRS is a large site, and most groundwater contamination is located in its central areas. However, the potential for offsite migration exists, and the consequences of such an outcome are serious enough to warrant a comprehensive prevention program.

SRS has evaluated groundwater flow and determined, for each aquifer, where groundwater flows across the site boundary, since the location of groundwater flow would be a conservative surrogate for any potential contaminant migration.

Another pathway for existing groundwater contamination to flow offsite is by discharge into surface streams and subsequent transport into the Savannah River. SRS monitors site streams for contamination, and new wells have been installed in recent years along several site streams to detect contamination before it enters the stream and to assess its concentration in groundwater.

The groundwater monitoring program at SRS gathers information to determine the effect of site operations on groundwater quality. The program is designed to

- $\quad$ assist SRS in complying with environmental regulations and DOE directives

- $\quad$ provide data to identify and monitor constituents in the groundwater

- $\quad$ permit characterization of new facility locations to ensure that they are suitable for the intended facilities

- $\quad$ support basic and applied research projects

The groundwater monitoring program at SRS includes two primary components: (1) waste site/remediation groundwater monitoring, overseen by the Geochemical Monitoring (GM) group of the Soil and Groundwater Closure Projects Department, and (2) groundwater surveillance monitoring, conducted by the Environmental Services Section. To assist other departments in meeting their responsibilities, personnel of both organizations provide the services for installing monitoring wells, collecting and analyzing samples, and reporting results.

\section{Sample Scheduling and Collection}

The Geotechnical Monitoring group and the Environmental Services Section schedule groundwater sampling either in response to specific requests from SRS personnel or as part of their ongoing groundwater monitoring program. These groundwater samples provide data for reports required by federal and state regulations and for internal reports and research projects. The groundwater monitoring program schedules wells to be sampled at intervals ranging from quarterly to triennially.

Constituents that may be analyzed are commonly imposed by permit or work plan approval. These include metals, field parameters, suites of herbicides, pesticides, volatile organics, and others. Radioactive constituents that may be analyzed by request include gross alpha and beta measurements, gamma emitters, iodine-129, strontium-90, radium isotopes, uranium isotopes, and other alpha and beta emitters.

Groundwater samples are collected from monitoring wells, generally with either pumps or bailers dedicated to the well to prevent cross-contamination among wells. Occasionally, portable sampling equipment is used; this equipment is decontaminated between wells.

Sampling and shipping equipment and procedures are consistent with EPA, SCDHEC, and U.S. Department of Transportation guidelines. EPA-recommended preservatives and sample-handling techniques are used during sample storage and transportation to both onsite and offsite analytical laboratories. Potentially radioactive samples are screened for total activity (alpha and beta emitters) prior to shipment to determine appropriate packaging and labeling requirements.

Deviations (caused by dry wells, inoperative pumps, etc.) from scheduled sampling and analysis for 2003 are entered into the site's groundwater database and issued in appropriate reports. 
The WSRC Environmental Compliance Manual (WSRC 3Q) provides details about the following aspects of the groundwater monitoring program:

- well siting, construction, maintenance, and abandonment

- $\quad$ sample planning

- $\quad$ sample collection and field measurements

- analysis

- data management

- $\quad$ related publications, files, and databases

Monitoring data are evaluated each year to identify unexpected results in any site wells that might indicate new or changing groundwater contamination.

SRS is cooperating with SCDHEC to develop and implement source water assessment and protection programs. After an assessment program has been approved and implemented, the SRS groundwater protection program will focus on protection efforts. The primary aspect of the source water assessment and protection programs will be wellhead protection, given that SRS derives its drinking water exclusively from groundwater. Other aspects will include strategies for preventing contamination and controlling existing contamination through the SRS program. The program will evaluate waste minimization, spill prevention and control, well abandonment, and future land use. More information about this initiative can be found at http// www.epa.gov/safewater/protect.html.

\section{Remediating Contaminated SRS Groundwater}

SRS has maintained an environmental restoration effort for many years. Soil and Groundwater Closure Projects personnel manage groundwater cleanup of contaminated groundwater associated with Resource Conservation and Recovery Act (RCRA) hazardous waste management facilities or Federal Facility Act units. Their mission is to aggressively manage the inactive waste site and groundwater cleanup program so that

- $\quad$ schedules for environmental agreements are consistently met

- the utilization of financial and technology resources are continually improved

- the overall risk posed by existing contaminated sites is continually reduced

The Soil and Groundwater Closure Projects strategy revolves around developing an appropriate regulatory framework for each waste site, assessing the degree and extent of contamination, and remediating the contaminated groundwater to its original beneficial use. In cases where that remediation goal is impractical, the intent is to prevent plume migration and exposure and to evaluate alternate methods of risk reduction.

\section{Groundwater Monitoring Results}

The first priority of the groundwater monitoring program at SRS is to ensure that contamination is not being transported from the site by groundwater flow. Contaminated groundwater at SRS discharges into site streams or the Savannah River. Nowhere have offsite wells been contaminated by groundwater from SRS, and only a few site locations have groundwater with even a remote chance of contaminating such wells.

One of these locations is near A-Area/M-Area, the site of a large chlorinated solvent plume. This area's groundwater monitoring program uses more than 200 wells, and some of the contaminated wells lie within a half-mile of the site boundary. While it is believed that the major component of groundwater flow is not directly toward the site boundary, flow in the area is complex and difficult to predict. For this reason, particular attention is paid to data from wells along the site boundary and from those between A-Area/M-Area and the nearest population center, Jackson, South Carolina (figure 19 in the "SRS Maps" appendix on the CD accompanying this report). During 2003, no chlorinated organics were detected in any of these wells. Several wells at the JAX 1 and JAX 2 locations had low concentrations of toluene, but the maximum concentration, $64.8 \mathrm{ppb}$, was well below the Primary Drinking Water Standard of 1,000 ppb.

Another part of the SRS perimeter that has received special monitoring attention is across the Savannah River in Georgia's Burke and Screven counties. Since 1988, there has been speculation that tritiated groundwater from SRS could flow under the river and find its way into Georgia wells. Considerable effort has been directed at assessing the likelihood of transriver flow, and 44 wells have been drilled by the USGS and the Georgia Department of Natural Resources (figure 20 in the "SRS Maps" appendix on the CD accompanying this report). To this point, those efforts have failed to produce evidence of transriver flow into Georgia. In fact, mathematical modeling indicates that transriver contamination of Georgia wells is virtually impossible.

However, SRS continues to maintain and sample the Georgia monitoring wells annually. Tritium was detected in only three of these wells in 2003. The maximum concentration detected was $1.08 \mathrm{pCi} / \mathrm{mL}$ - 
well below EPA's maximum contaminant level of 20 $\mathrm{pCi} / \mathrm{mL}$.

Although contaminated groundwater in most SRS areas does not threaten the site boundary, it does have the potential to impact site streams. For this reasonand because of the need to meet the requirements of various environmental regulations-extensive monitoring is conducted around SRS waste sites and operating facilities, regardless of their proximity to the boundary. For details about this monitoring and the conditions at individual sites, one should refer to site-specific documents, such as RCRA corrective action reports or RCRA/Comprehensive Environmental Response, Compensation, and Liability Act RCRA facility investigation/remedial investigation reports.

Table 6-1 presents a general picture of groundwater conditions at SRS based on 2002 and 2003 monitoring data. The table shows the 2003 maximum concentrations for major constituents in the SRS areas that have contaminated groundwater - and how these concentrations compare to the drinking water standards and the 2002 maximums. The table also shows where the contaminated water is most likely to outcrop.

The results shown are maximum values generally associated with wells very close to the contaminant source areas. The contaminants that eventually reach the streams some distance away usually have undergone considerable dilution and/or natural degradation. Hence, the water actually entering the streams often is at much lower concentrations than the observed maximums.

The table covers the most severely contaminated areas at SRS. In most cases, the maximum concentrations did not change significantly between 2002 and 2003. 
Table 6-1

Summary of Maximum Groundwater Monitoring Results for Major Areas Within SRS, 2002-2003

Page 1 of 1

\begin{tabular}{|c|c|c|c|c|c|c|}
\hline Location & $\begin{array}{l}\text { Major } \\
\text { Contaminants }\end{array}$ & Units & $\begin{array}{l}2003 \\
\text { Maximum }\end{array}$ & MCL & $\begin{array}{l}2002 \\
\text { Maximum }\end{array}$ & Likely Outcrop Point \\
\hline A-Area/M-Area & $\begin{array}{l}\text { TCE } \\
\text { PCE }\end{array}$ & $\begin{array}{l}\mathrm{ppb} \\
\mathrm{ppb}\end{array}$ & $\begin{array}{l}38,300 \\
125,000\end{array}$ & $\begin{array}{l}5 \\
5\end{array}$ & $\begin{array}{l}46,400 \\
155,000\end{array}$ & $\begin{array}{l}\text { Tims Branch/Upper } \\
\text { Three Runs Creek in } \\
\text { East; Crackerneck } \\
\text { Swamp in West }\end{array}$ \\
\hline C-Area & $\begin{array}{l}\text { TCE } \\
\text { Tritium }\end{array}$ & $\begin{array}{l}\mathrm{ppb} \\
\mathrm{pCi} / \mathrm{L}\end{array}$ & $\begin{array}{l}8,330 \\
6,020,000\end{array}$ & $\begin{array}{l}5 \\
20,000\end{array}$ & $\begin{array}{l}10,500 \\
8,620,000\end{array}$ & $\begin{array}{l}\text { Tributaries of Fourmile } \\
\text { Branch }\end{array}$ \\
\hline D-Area & $\begin{array}{l}\text { TCE } \\
\text { Tritium }\end{array}$ & $\begin{array}{l}\mathrm{ppb} \\
\mathrm{pCi} / \mathrm{L}\end{array}$ & $\begin{array}{l}425 \\
1,340,000\end{array}$ & $\begin{array}{l}5 \\
20,000\end{array}$ & $\begin{array}{l}319 \\
1,470,000\end{array}$ & Savannah River Swamp \\
\hline E-Area & $\begin{array}{l}\text { Tritium } \\
\text { TCE }\end{array}$ & $\begin{array}{l}\mathrm{pCi} / \mathrm{L} \\
\mathrm{ppb}\end{array}$ & $\begin{array}{l}105,000,000 \\
372\end{array}$ & $\begin{array}{l}20,000 \\
5\end{array}$ & $\begin{array}{l}38,700,000 \\
192\end{array}$ & $\begin{array}{l}\text { Upper Three } \\
\text { Runs/Crouch Branch in } \\
\text { North; Fourmile Branch } \\
\text { in South }\end{array}$ \\
\hline F-Area & $\begin{array}{l}\text { TCE } \\
\text { Tritium } \\
\text { Gross alpha } \\
\text { Beta }\end{array}$ & $\begin{array}{l}\mathrm{ppb} \\
\mathrm{pCi} / \mathrm{L} \\
\mathrm{pCi} / \mathrm{L} \\
\mathrm{pCi} / \mathrm{L}\end{array}$ & $\begin{array}{l}32.4 \\
1,570,000 \\
109 \\
1380\end{array}$ & $\begin{array}{l}5 \\
20,000 \\
15 \\
4 \mathrm{mrem} / \mathrm{yr}\end{array}$ & $\begin{array}{l}25 \\
1,860,000 \\
222 \\
422\end{array}$ & $\begin{array}{l}\text { Upper Three } \\
\text { Runs/Crouch Branch in } \\
\text { North; Fourmile Branch } \\
\text { in South }\end{array}$ \\
\hline $\begin{array}{l}\text { F Seepage } \\
\text { Basins }\end{array}$ & $\begin{array}{l}\text { Tritium } \\
\text { Gross alpha } \\
\text { Beta }\end{array}$ & $\begin{array}{l}\mathrm{pCi} / \mathrm{L} \\
\mathrm{pCi} / \mathrm{L} \\
\mathrm{pCi} / \mathrm{L}\end{array}$ & $\begin{array}{l}10,500,000 \\
1100 \\
2,640\end{array}$ & $\begin{array}{l}20,000 \\
15 \\
4 \mathrm{mrem} / \mathrm{yr}\end{array}$ & $\begin{array}{l}12,000,000 \\
800 \\
2,740\end{array}$ & Fourmile Branch \\
\hline $\mathrm{H}$-Area & $\begin{array}{l}\text { Tritium } \\
\text { TCE } \\
\text { Gross alpha }^{a} \\
\text { Beta }^{a}\end{array}$ & $\begin{array}{l}\mathrm{pCi} / \mathrm{L} \\
\mathrm{ppb} \\
\mathrm{pCi} / \mathrm{L} \\
\mathrm{pCi} / \mathrm{L}\end{array}$ & $\begin{array}{l}128,000 \\
13 \\
16.3 \\
694\end{array}$ & $\begin{array}{l}20,000 \\
5 \\
15 \\
4 \mathrm{mrem} / \mathrm{yr}\end{array}$ & $\begin{array}{l}145,000 \\
10.7 \\
11.9 \\
66.9\end{array}$ & $\begin{array}{l}\text { Upper Three } \\
\text { Runs/Crouch Branch in } \\
\text { North; Fourmile Branch } \\
\text { in South }\end{array}$ \\
\hline $\begin{array}{l}\text { H Seepage } \\
\text { Basins }\end{array}$ & $\begin{array}{l}\text { Tritium } \\
\text { Gross alpha } \\
\text { Beta }\end{array}$ & $\begin{array}{l}\mathrm{pCi} / \mathrm{L} \\
\mathrm{pCi} / \mathrm{L} \\
\mathrm{pCi} / \mathrm{L}\end{array}$ & $\begin{array}{l}8,590,000 \\
204 \\
1,870\end{array}$ & $\begin{array}{l}20,000 \\
15 \\
4 \mathrm{mrem} / \mathrm{yr}\end{array}$ & $\begin{array}{l}8,580,000 \\
30 \\
1,210\end{array}$ & Fourmile Branch \\
\hline R-Area & Tritium & $\mathrm{pCi} / \mathrm{L}$ & 121,000 & 20,000 & 168,000 & $\begin{array}{l}\text { Mill Creek in Northwest; } \\
\text { tributaries of PAR } \\
\text { Pond elsewhere }\end{array}$ \\
\hline K-Area & $\begin{array}{l}\text { Tritium } \\
\text { TCE }\end{array}$ & $\begin{array}{l}\mathrm{pCi} / \mathrm{L} \\
\mathrm{ppb}\end{array}$ & $\begin{array}{l}59,922,000 \\
42.7\end{array}$ & $\begin{array}{l}20,000 \\
5\end{array}$ & $\begin{array}{l}78,200,000 \\
23\end{array}$ & Indian Graves Branch \\
\hline L-Area & $\begin{array}{l}\text { Tritium } \\
\text { TCE }\end{array}$ & $\begin{array}{l}\mathrm{pCi} / \mathrm{L} \\
\mathrm{ppb}\end{array}$ & $\begin{array}{l}1,052,910 \\
41.6\end{array}$ & $\begin{array}{l}20,000 \\
5\end{array}$ & $\begin{array}{l}2,260,000 \\
9.07\end{array}$ & L Lake \\
\hline P-Area & $\begin{array}{l}\text { Tritium } \\
\text { TCE }^{\mathrm{a}}\end{array}$ & $\begin{array}{l}\mathrm{pCi} / \mathrm{L} \\
\mathrm{ppb}\end{array}$ & $\begin{array}{l}2,840,000 \\
14,800\end{array}$ & $\begin{array}{l}20,000 \\
5\end{array}$ & $\begin{array}{l}19,100,000 \\
35,500\end{array}$ & $\begin{array}{l}\text { Steel Creek in North; } \\
\text { Meyer's Branch in South }\end{array}$ \\
\hline $\begin{array}{l}\text { Sanitary } \\
\text { Landfill }\end{array}$ & $\begin{array}{l}\text { TCE } \\
\text { Vinyl chloride }\end{array}$ & $\begin{array}{l}\mathrm{ppb} \\
\mathrm{ppb}\end{array}$ & 10.380 .1 & $\begin{array}{l}5 \\
2\end{array}$ & $\begin{array}{l}22.3 \\
244\end{array}$ & Upper Three Runs Creek \\
\hline TNX & TCE & $\mathrm{ppb}$ & 1,660 & 5 & 1,680 & Savannah River Swamp \\
\hline CMP Pits & TCE & $\mathrm{ppb}$ & 1,850 & 5 & 2,240 & Pen Branch \\
\hline
\end{tabular}

a Data from 2002 and 2003 are not directly comparable because of differences in sampling methods/locations. 



\title{
Chapter 7
}

\section{Quality Assurance}

\author{
Moheb Khalil \\ Environmental Bioassay Laboratory
}

Donald Padgett and Monte Steedley

Environmental Monitoring and Analysis Group

Jen Williams

ExR, Inc.

[Editor's note: The Environmental Monitoring Section (EMS) of the Savannah River Site (SRS) Environmental Protection Department (EPD) maintained the environmental quality assurance (QA) program through 2002. As part of the site's reorganization, effective the beginning of 2003, this responsibility was divided among three groups-the Environmental Monitoring Laboratory (EML), the Environmental Monitoring and Analysis group (EMA), and the Geochemical Monitoring group (GM).]

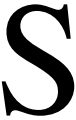
RS's environmental QA program is conducted to verify the integrity of data generated by onsite and subcontracted environmental laboratories.

The program's objectives are to ensure that samples are representative of the surrounding environment and that analytical results are accurate.

This chapter summarizes the 2003 QA program. Guidelines and applicable standards for the program are referenced in appendix A, "Applicable Guidelines, Standards, and Regulations."

Tables containing the 2003 QA data and the nonradiological detection limits can be found on the $\mathrm{CD}$ accompanying this report.

A more complete description of the QA program can be found in Savannah River Site Environmental Monitoring Program (WSRC-3Q1-2, Section 1100) and in the Savannah River Site Environmental Monitoring Section Quality Assurance Plan (WSRC3Q1-2, Section 8000).

The 2003 QA data and program reviews demonstrate that the data in this annual report are reliable and meet applicable standards.

\section{QA for EMA Laboratories}

\section{Internal Quality Assurance Program}

\section{Field Sampling Group}

EMA and EML personnel routinely conduct a blind sample program for field measurements of $\mathrm{pH}$ to assess the quality and reliability of field data measurements. EMA personnel also measure total residual chlorine, dissolved oxygen, and temperature in water samples; but because of the difficulties in providing field standards, these measurements are not suitable for a blind sample program.

During 2003, blind pH field measurements were taken for 24 samples. All field $\mathrm{pH}$ measurements were within the U.S. Environmental Protection Agency's (EPA's) suggested acceptable control limit of $\pm 0.4 \mathrm{pH}$ units of the true (known) value.

\section{Chemistry and Counting Laboratories}

Blind Tritium Samples Blind tritium samples provide a continuous assessment of laboratory sample preparation and counting. During 2003, 12 blind samples were analyzed for tritium; all the results were within the control limits.

Laboratory Certification EML is certified by the South Carolina Department of Health and Environmental Control (SCDHEC) Office of Laboratory Certification for the following analytes:

- $\quad$ under the Clean Water Act (CWA) - chemical oxygen demand, total suspended solids, field $\mathrm{pH}$, total residual chlorine, temperature, and 26 metals

- under the Resource Conservation and Recovery Act (RCRA) - 50 volatile organic compounds (VOCs) and 27 metals 
Table 7-1 Subcontract Laboratory Performance in ERA Water Pollution Studies

\begin{tabular}{lc}
\hline Laboratory & $\begin{array}{c}\text { Water Pollution Studies } \\
\text { (Percent Acceptable) }^{\mathrm{a}}\end{array}$ \\
\hline Lionville & WP 102(98\%) \\
General Engineering & WP $98(98 \%)^{\mathrm{c}}$ \\
General Engineering Mobile Lab & WP $99(100 \%)$ \\
Shealy Environmental Services & WP $101(94 \%)^{\mathrm{d}}$ \\
\hline a $\quad$ Laboratories are expected to exceed 80-percent-acceptable results. \\
b $\quad$ The result for tetrachloroethane, aroclor-1260, hardness, oil and grease, alkalinity, and chloride were not acceptable. \\
c $\quad$ Results for biological oxygen demand, chemical oxygen demand, orthophosphate (as phosphorus), and iron were not \\
acceptable.
\end{tabular}

\section{External Quality Assurance Program}

In 2003, EML participated in the U.S. Department of Energy (DOE) Quality Assurance Program (QAP), an interlaboratory comparison program that tracks performance accuracy and tests the quality of environmental data reported to DOE by its contractors.

For a radiological laboratory intercomparison in 2003, the analysis of 43 isotopes was completed in March on the 58th set of QAP samples, and the analysis of four isotopes was completed in September on the 59th set. A performance rating of 95-percent acceptable was achieved on the 58th set; the rating for the 59th set was 100-percent acceptable. This rating was calculated by dividing the "acceptables" and the "acceptable with warnings" by the total number of results. Environmental QA personnel consider 80 percent to be the minimum acceptance rating in this program.

Detailed QAP intercomparison study results can be found in the data tables section of the $\mathrm{CD}$ accompanying this report.

\section{QA for Subcontracted Laboratories/EMA Laboratories}

Subcontracted environmental laboratories providing analytical services must have a documented QA program and meet the quality requirements defined in the WSRC Quality Assurance Manual (WSRC 1Q).

An annual evaluation of each subcontracted laboratory is performed to ensure that all the laboratories maintain technical competence and follow the required QA programs. Each evaluation includes an examination of laboratory performance with regard to sample receipt, instrument calibration, analytical procedures, data verification, data reports, records management, nonconformance and corrective actions, and preventive maintenance. Reports of the findings and recommendations are provided to each laboratory, and follow=up evaluations are conducted as necessary.

\section{Nonradiological Liquid Effluents}

Effluent samples are analyzed by three onsite laboratories and two subcontracted laboratories. Laboratories must be certified by SCDHEC for all National Pollutant Discharge Elimination System (NPDES) analyses.

\section{Interlaboratory Comparison Program}

During 2003, EMA- and GM-subcontracted laboratories participated in the Environmental Resource Associates (ERA) WatR ${ }^{\text {TM }}$ Pollution Proficiency Testing (PT) Studies, which include various InterlaB

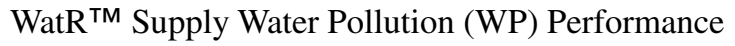
Evaluation Programs. Performance results by the subcontracted laboratories can be found in table 7-1.

The proficiency rating is calculated as follows: acceptable parameters divided by total parameters analyzed, multiplied by 100 .

EPA uses PT results to certify laboratories for specific analyses. As part of the recertification process, EPA requires that subcontracted laboratories investigate the outside-acceptance-limit results and implement corrective actions as appropriate.

Laboratories (commercial and government) that analyze NPDES samples participate in the Discharge Monitoring Report-Quality Assurance (DMR-QA) study or the WP study. Under this program, the laboratories obtain test samples from ERA. This 
provider, as required by EPA, is accredited by the National Institute of Standards and Technology. For the 2003 DMR-QA study, Shealy Environmental Services, Inc. (SES) used the WP 101 and 102 studies; EML used the WP 100 study; and the WSRC Site Utilities Division (SUD) used the WP 101 study.

SES reported acceptable results for 16 of 17 NPDES parameters; EML reported acceptable results for 14 of 16 NPDES parameters; and the SUD Wastewater Laboratory reported acceptable results for three of three NPDES parameters.

All laboratories that participated in the DMR-QA study and experienced "not acceptable" results identified analytical problems and made corrections as necessary to pass the follow-up WP analyses and maintain SCDHE certification.

\section{Intralaboratory Comparison Program}

The environmental monitoring intralaboratory program compares performance within a laboratory by analyzing duplicate and blind samples throughout the year.

SES, EML, and EMA analyzed 91 duplicate samples during 2003. Zero difference results were reported for 61 of these samples.

Percent difference calculations showed that nine of the 91 duplicate samples analyzed were outside the EMA internal QA requirement $( \pm 20$ percent of the true value). None of the exceptions resulted in a difference value that was greater than the parameter detection limit. These exceptions appeared to be related to an analytical error, sample contamination, or improper sampling techniques. Generally, exceptions in this range are not considered a problem.

SES, EML, and EMA analyzed 98 blind samples during 2003. Zero difference results were reported for 66 of these samples.

Percent difference calculations showed that 11 of the 98 blind samples analyzed were outside the EMA internal QA requirement $( \pm 20$ percent of the true value). Six of the exceptions resulted in a difference value that was greater than the parameter detection limit. These exceptions appeared to be related to an analytical error, sample contamination, or improper sampling techniques. Generally, exceptions in this range are not considered a problem.

Results for the duplicate and blind sampling programs met expectations, with no indications of consistent problems in the laboratories.

\section{Stream and River Water Quality}

SRS's water quality program requires checks of 10 percent of the samples to verify analytical results. Duplicate grab samples from SRS streams and the Savannah River were analyzed by SES and EMA in 2003. Most results were within the \pm acceptance limits. Detailed stream and Savannah River water quality duplicate sample results can be found in the data tables section of the $\mathrm{CD}$ accompanying this report.

\section{Groundwater}

Groundwater analyses at SRS are performed by subcontracted laboratories. SRS requires that the laboratories investigate the outside-acceptance-limit results and implement corrective actions as appropriate.

\section{Internal QA}

During 2003, approximately 5 percent of the samples collected (radiological and nonradiological) for the RCRA and the Comprehensive Environmental Response, Compensation, and Liability Act (CERCLA) programs were submitted to the primary laboratory for analysis as blind duplicates and to a different laboratory as a QA check. The laboratories' results were evaluated on the basis of the percentage within an acceptable concentration range.

Generally, results for all QA evaluations were found to be within control limits in 2003. Full results for all QA evaluations can be obtained by contacting the EMA manager at 803-952-6931.

\section{External QA (Environmental Resource Associates Standards)}

Quarterly Assessments During 2003, Soil and Groundwater Closure Projects (SGCP) personnel conducted quality assessments of the primary analytical laboratories to review the department's performance on certain analyses. Each laboratory received a set of certified environmental quality control standards from ERA, and its results were compared with the ERA-certified values and performance acceptance limits. The performance acceptance limits closely approximate the 95-percent confidence interval.

Results from the laboratories (EBL, General Engineering, General Engineering Mobile, Lionville,

Microseeps, and Sanford Cohen and Associates) for the first three quarters are summarized in table 7-2 (fourth-quarter results not available in time for publication in this report). The results show that all the 
Table 7-2 Subcontract Laboratory Performance on Environmental Resource Associates (ERA) Standards

\begin{tabular}{|c|c|c|c|c|}
\hline \multicolumn{2}{|c|}{ Laboratory } & 1st Quarter 2003 & 2nd Quarter 2003 & 3rd Quarter 2003 \\
\hline \multicolumn{2}{|c|}{ EBL } & $96.6 \%$ a & $92.4 \% \mathrm{~b}$ & $92.9 \%{ }^{c}$ \\
\hline \multicolumn{2}{|c|}{ General Engineering } & $98.9 \% d$ & $97.5 \%$ e & $97.5 \%$ \\
\hline \multicolumn{2}{|c|}{ GE Mobile Lab } & $100 \%$ & $98.0 \% \mathrm{~g}$ & $98.6 \% \mathrm{~h}$ \\
\hline \multicolumn{2}{|c|}{ Lionville (Recra) } & $97.7 \%$ & $100 \%$ & $98.9 \%$ j \\
\hline \multicolumn{2}{|c|}{ Microseeps } & $96.9 \% \mathrm{k}$ & $94.1 \%$ & $97.3 \% \mathrm{~m}$ \\
\hline \multicolumn{2}{|c|}{ Sanford Cohen \& Assoc. } & - & $55.6 \% n$ & $55.6 \% \circ$ \\
\hline a & \multicolumn{4}{|c|}{ Results for 1,1-dichloroethylene and zinc were not acceptable. } \\
\hline b & \multicolumn{4}{|c|}{ Results for antimony, gross alpha, mercury, nonvolatile beta, and strontium were not acceptable. } \\
\hline c & \multicolumn{4}{|c|}{ Results for antimony, cobalt- 60 , gross beta, mercury, and strontium were not acceptable. } \\
\hline d & \multicolumn{4}{|c|}{ Results for mercury and total phosphates (as phosphorus) were not acceptable. } \\
\hline e & \multicolumn{4}{|c|}{ Results for cesium-134, cobalt-60, phenols, silver, and total phosphates (as p) were not acceptable. } \\
\hline f & \multicolumn{4}{|c|}{ Results for cesium-134, chloride, grease \& oil, silver, and turbidity were not acceptable. } \\
\hline g & \multicolumn{4}{|c|}{ Results for cesium-134, cyanide, and di-n-butyl phthalate were not acceptable. } \\
\hline $\mathrm{h}$ & \multicolumn{4}{|c|}{ Results for silver and tritium were not acceptable; the duplicate result for tritium was within the PAL. } \\
\hline i & \multicolumn{4}{|c|}{ Results for cyanide, 2,4-D, 2,4,5-T, and PCB1242 were not acceptable. } \\
\hline j & \multicolumn{4}{|c|}{ Results for alkalinity and bromoform were not acceptable. } \\
\hline k & \multicolumn{4}{|c|}{ Results for acetone, anthracene, and n-nitrosodiphenylamine/diphenylamine were not acceptable. } \\
\hline I & \multicolumn{4}{|c|}{$\begin{array}{l}\text { Results for acetone, arsenic, chloromethane (methyl chloride), molybdenum, styrene, and } \mathrm{m} / \mathrm{p} \text {-xylene were not accept- } \\
\text { able. }\end{array}$} \\
\hline $\mathrm{m}$ & \multicolumn{4}{|c|}{ Results for aluminum, chromium, and copper were not acceptable. } \\
\hline $\mathrm{n}$ & \multicolumn{4}{|c|}{ Results for cesium-134, cesium-137, cobalt- 60 , and strontium-89 were not acceptable. } \\
\hline o & \multicolumn{4}{|c|}{ Results for cesium-134, cobalt-60, gross beta, and strontium-89 were not acceptable. } \\
\hline
\end{tabular}

laboratories except the Sanford Cohen facility exceeded the expected 80-percent-acceptable-results level. Sanford Cohen is not a full-service laboratory (radiological analysis only), and its performance in the 2003 DOE/QAP interlaboratory comparison program was considered acceptable. Radiological parameters were not included in the WSRC-administered QA program until 2003, and Sanford Cohen analyzed only eight radiological analytes. This made its percentage seem unacceptable when compared with the other (full service) laboratories, each of which analyzed and reported more than 200 analytes. SRS will evaluate Sanford Cohen's QA performance in January 2004 and request a corrective action plan.

\section{Soil/Sediment}

Environmental investigations of soils and sediments, primarily for RCRA/CERCLA units, are performed by subcontracted laboratories. Data from 2003 were validated by SGCP according to EPA standards for analytical data quality, unless specified otherwise by site customers.

The environmental validation program is based on two EPA guidance documents, Guidance for the Data
Quality Objectives Process for Superfund (EPA-540R-93-071) and Data Quality Objectives Process for Hazardous Waste Sites (G-4HW) (EPA-600/R-00007). These documents identify QA issues to be addressed, but they do not formulate a procedure for how to evaluate these inputs, nor do they propose pass/fail criteria to apply to data and documents. Hence, the validation program necessarily contains elements from - and is influenced by - several other sources, including

- Guidance on Environmental Data Verification and Data Validation (QA/G-8), EPA-240/R-02/ 004

- USEPA Contract Laboratory Program National Functional Guidelines for Organic Data Review, EPA-540/R-99/008

- USEPA Contract Laboratory Program National Functional Guidelines for Chlorinated Dioxin/ Furan Data Review, EPA-540/R-02/003

- USEPA Contract Laboratory Program National Functional Guidelines for Inorganic Data Review, EPA-540/R-01/008 
- Test Methods for Evaluating Solid Waste, EPA, November 1986, SW-846, Third Edition

- DOE Quality Systems for Analytical Services, Revision 0, July, 2003

Relative percent difference for the soil/sediment program is calculated for field duplicates and laboratory duplicates. Generally, results for all QA evaluations were found to be within control limits in 2003. A summary of this information is presented in each project report prepared by SGCP personnel.

\section{Data Review}

The QA program's detailed data review for groundwater and soil/sediment analyses is described in WSRC3Q1-2, Section 1100.

In 2003, the major QA issues discovered and addressed in connection with these programs for soil/ sediment and groundwater analyses included the following:

- false positives of curium-245/246 systematically reported without qualification at one subcontract laboratory
- $\quad$ quantitation limits reported in place of results for detected analytes over a brief period at another subcontract laboratory

- various problems transitioning an in-house laboratory to environmental groundwater work

- data recording problems (temperature and sample association) on chains-of-custody by a sampling contractor

Items identified in 2003 that are still being addressed include the following:

- inability to demonstrate the absence of spectral interference for liquid scintillation counter radioisotopes at one subcontract laboratory

- inconsistent application of qualification policy for basic quantitation and blank contamination across all but one of the laboratories

These findings illustrate that, although laboratory procedures are well defined, analytical data quality does benefit from technical scrutiny. A corrective action plan has been put into place to address these issues, which are expected to be resolved during 2004. 



\section{Appendix $A$}

\section{Applicable Guidelines, Standards, and Regulations}

$\mathrm{T}$ HE Savannah River Site (SRS) environmental monitoring program is designed to meet state and federal regulatory requirements for radiological and nonradiological programs. These requirements are stated in U.S. Department of Energy (DOE) Order 5400.5, "Radiation Protection of the Public and the Environment"; in the Clean Air Act [Standards of Performance for New Stationary Sources, also referred to as New Source Performance Standards (NSPS), and the National Emission Standards for Hazardous Air Pollutants (NESHAP)]; in the Comprehensive Environmental Response, Compensation, and Liability Act (CERCLA - also known as Superfund); in the Resource Conservation and Recovery Act (RCRA); in the Clean Water Act (i.e., National Pollutant Discharge Elimination SystemNPDES); and in the National Environmental Policy Act (NEPA). Compliance with environmental requirements is assessed by DOE-Savannah River (DOESR), the South Carolina Department of Health and Environmental Control (SCDHEC), and the U.S. Environmental Protection Agency (EPA).

The SRS environmental monitoring program's objectives incorporate recommendations of

- the International Commission on Radiological Protection (ICRP) in Principles of Monitoring for the Radiation Protection of the Population, ICRP Publication 43
- $\quad$ DOE Order 5400.5

- $\quad$ DOE/EH-0173T, "Environmental Regulatory Guide for Radiological Effluent Monitoring and Environmental Surveillance"

Detailed information about the site's environmental monitoring program is documented in Section 1111 (SRS EM Program) of the SRS Environmental Monitoring Section Plans and Procedures, WSRC$3 \mathrm{Q} 1-2$, Volume 1 . This document is reviewed annually and updated every 3 years.

SRS has implemented and adheres to the SRS Environmental Management System Policy. Implementation of a formal Environmental Management System (EMS), such as that described in the International Organization for Standardization (ISO) 14001 standard, is an Executive Order 13148 ("Greening the Government Through Leadership in Environmental Management”) and DOE Order 450.1 ("Environmental Protection Program") requirement. SRS maintains an EMS that fully meets the requirements of ISO 14001. The full text of the SRS EMS Policy is included at the end of this appendix.

Drinking water standards (DWS) can be found at http:/ /www.epa.gov/safewater/mcl.html on the Internet, and maximum allowable concentrations of toxic air pollutants can be found at http://www.scdhec.net/baq. More information about certain media is presented in this appendix.

\section{Air Effluent Discharges}

DOE Order 5400.5 establishes Derived Concentration Guides (DCGs) for radionuclides in air. DCGs, calculated by DOE using methodologies consistent with recommendations found in ICRP publications 26 (Recommendations of the International Commission on Radiological Protection) and 30 (Limits for the Intake of Radionuclides by Workers), are used as reference concentrations for conducting environmental protection programs at DOE sites. DCGs are not considered release limits. DCGs for radionuclides in air are discussed in more detail on page 73 .
Radiological airborne releases also are subject to EPA regulations cited in 40 CFR 61, "National Emission Standards for Hazardous Air Pollutants," Subpart H ("National Emission Standards for Emissions of Radionuclides Other Than Radon from Department of Energy Facilities").

Regulation of radioactive and nonradioactive air emissions - both criteria pollutants and toxic air pollutants - has been delegated to SCDHEC. Therefore, SCDHEC must ensure that its air pollution 
regulations are at least as stringent as federal regulations required by the Clean Air Act. This is accomplished by SCDHEC Regulation 61-62, "Air Pollution Control Regulations and Standards." As with many regulations found in the Code of Federal Regulations (CFR), many of SCDHEC's regulations and standards are source specific. Each source of air pollution at SRS is permitted or exempted by SCDHEC, with specific emission rate limitations or special conditions identified. The bases for the limitations and conditions are the applicable South Carolina air pollution control regulations and standards. In some cases, specific applicable CFRs also are cited in the permits issued by SCDHEC. The applicable SCDHEC regulations are too numerous to discuss here, so only the most significant are listed.

A total of 256 toxic air pollutants and their respective allowable site boundary concentrations are identified in Regulation 61-62.5, Standard No. 8, "Toxic Air Pollutants." As with Standard No. 2, "Ambient Air Quality Standards," compliance is determined by air dispersion modeling. Toxic air pollutants can be found at http://www.scdhec.net/baq.

SCDHEC airborne emission standards for each SRS permitted source may differ, based on size and type of facility, type and amount of expected emissions, and the year the facility was placed into operation. For example, SRS powerhouse coal-fired boilers are regulated by Regulation 61-62.5, Standard No. 1, "Emissions From Fuel Burning Operations." This standard specifies that for powerhouse stacks built before February 11, 1971, the opacity standard is 40 percent. For new sources constructed after this date, the opacity standard typically is 20 percent. The standards for particulate and sulfur dioxide emissions are shown in table A-2.

Regulation 61-62.5, Standard No. 4, "Emissions from Process Industries," is applicable to all SRS sources except those regulated by a different source-specific standard. For some SRS sources, particulate matter emission limits depend on the weight of the material being processed and are determined from a table in the regulation. For process and diesel engine stacks in existence on or before December 31, 1985, emissions shall not exhibit an opacity greater than 40 percent. For new sources, where construction began after December 31,1985 , the opacity standard is 20 percent.

Two SCDHEC standards, which govern criteria and toxic air pollutants and ambient air quality, are applicable to all SRS sources. Regulation 61-62.5,
Standard No. 2, "Ambient Air Quality Standards," identifies eight criteria air pollutants commonly used as indices of air quality (e.g., sulfur dioxide, nitrogen dioxide, and lead) and provides allowable site boundary concentrations for each pollutant, as well as the measuring intervals. Compliance with the various pollutant standards is determined by conducting air dispersion modeling for all sources of each pollutant, using EPA-approved dispersion models and then comparing the results to the standard. The pollutants, measuring intervals, and allowable concentrations are provided in table $\mathrm{A}-1$. The standards are in micrograms per cubic meter, unless noted otherwise.

As previously mentioned, some SRS sources have both SCDHEC and CFRs applicable and identified in their permits. For the package steam generating boilers

\section{Table A-1 Criteria Air Pollutants}

\begin{tabular}{|c|c|c|}
\hline Pollutant & Interval & $\mu \mathbf{g} / \mathbf{m}^{3 a, b}$ \\
\hline Sulfur Dioxide & $\begin{array}{l}3 \text { hours } \\
24 \text { hours } \\
\text { annual }\end{array}$ & $\begin{array}{l}1300 \\
365 \\
80\end{array}$ \\
\hline $\begin{array}{l}\text { Total Suspended } \\
\text { Particulates }\end{array}$ & $\begin{array}{l}\text { Annual Geometric } \\
\text { Mean }\end{array}$ & 75 \\
\hline PM10 & $\begin{array}{l}24 \text { hours } \\
\text { annual }\end{array}$ & $\begin{array}{l}150^{d} \\
50^{d}\end{array}$ \\
\hline Carbon Monoxide & $\begin{array}{l}1 \text { hour } \\
8 \text { hours }\end{array}$ & $\begin{array}{l}40 \mathrm{mg} / \mathrm{m}^{3} \\
10 \mathrm{mg} / \mathrm{m}^{3}\end{array}$ \\
\hline Ozone & 1 hour & $0.12 p p m^{d, e}$ \\
\hline $\begin{array}{l}\text { Gaseous Fluorides } \\
\text { (as HF) }\end{array}$ & $\begin{array}{l}\text { 12-hour average } \\
24 \text {-hour average } \\
1 \text {-week average }\end{array}$ & $\begin{array}{l}3.7 \\
2.9 \\
1.6\end{array}$ \\
\hline Nitrogen Dioxide & annual & 100 \\
\hline Lead & $\begin{array}{l}\text { Calendar Quarterl } \\
\text { Mean }\end{array}$ & 1.5 \\
\hline
\end{tabular}

a Arithmetic average except in case of total suspended particulate matter (TSP)

b At $25^{\circ} \mathrm{C}$ and $760 \mathrm{~mm} \mathrm{Hg}$

c Not to be exceeded more than once a year

d Attainment determinations will be made based on the criteria contained in appendices $\mathrm{H}$ and K, 40 CFR 50 , July 1, 1987.

e New ozone standard promulgated in CFR but not yet incorporated into SC State Implementation Plan and regulations. Standard based on 8-hour average of 0.080 ppm, with nonattainment designation based on fourth exceedance 


\section{Table A-2 Airborne Emission Standards for SRS Coal-Fired Boilers}

\begin{tabular}{ll} 
Sulfur Dioxide & $3.6 \mathrm{lb} / 10^{6} \mathrm{Btu}^{\mathrm{a}}$ \\
$\begin{array}{l}\text { Total Suspended } \\
\text { Particulates }\end{array}$ & $0.6 \mathrm{~b} / 10^{6} \mathrm{Btu}$ \\
Opacity & $40 \%$ \\
\hline a British thermal unit & \\
\hline
\end{tabular}

in K-Area and two portable package boilers, both SCDHEC and federal regulations are applicable. The standard for sulfur dioxide emissions is specified in 40 CFR 60, Subpart Dc, "Standards of Performance for Small Industrial-Commercial-Institutional Steam Generating Units," while the standard for particulate matter is found in Regulation 61-62.5, Standard No.

1. Because these units were constructed after applicability dates found in both regulations, the opacity limit for the units is the same in both regulations. The emissions standards for these boilers are presented in table A-3.

Another federal regulation, 40 CFR 60, Subpart Kb, "Standards of Performance for Volatile Organic Liquid
Storage Vessels (Including Petroleum Liquid Storage Vessels) for which Construction, Reconstruction, or Modification Commenced after July 23, 1984," specifies types of emission controls that must be incorporated into the construction of a source. In this regulation, the type of control device required depends on the size of the tank and the vapor pressures of the material being stored. The regulation is applicable to several sources at SRS, such as the two 30,000-gallon No. 2 fuel oil storage tanks in K-Area and the four mixed solvent storage tanks in H-Area. However, because of the size of these tanks and the vapor pressures of the materials being stored, the tanks are not required to have control devices. The only requirements applicable to SRS storage tanks are those for record keeping.

Table A-3 Airborne Emission Standards for SRS Fuel Oil-Fired Package Boilers

\begin{tabular}{ll}
\hline Sulfur Dioxide & $0.5 \mathrm{lb} / 10^{6} \mathrm{Btu}$ \\
$\begin{array}{l}\text { Total Suspended } \\
\text { Particulates }\end{array}$ & $0.6 \mathrm{~b} / 10^{6} \mathrm{Btu}$ \\
Opacity & $20 \%$ \\
\hline
\end{tabular}

\section{(Process) Liquid Effluent Discharges}

DOE Order 5400.5 establishes DCGs for radionuclides in process effluents. (DCGs for radionuclides in liquid are discussed in more detail on page 73.) DCGs were calculated by DOE using methodologies consistent with recommendations found in ICRP, 1987 and ICRP, 1979 and are used

- as reference concentrations for conducting environmental protection programs at DOE sites

- as screening values for considering best available technology for treatment of liquid effluents

DOE Order 5400.5 exempts aqueous tritium releases from best available technology requirements but not from ALARA (as low as reasonably achievable) considerations.
Three NPDES permits are in place that allow SRS to discharge water into site streams and the Savannah River: one industrial wastewater permit (SC0000175) and two stormwater runoff permits (SCR000000 for industrial discharges and SCR100000 for construction discharges).

A fourth permit (ND0072125) is a no-discharge water pollution control land application permit that regulates sludge generated at onsite sanitary waste treatment plants.

Detailed requirements for each permitted discharge point-including parameters sampled for, permit limits for each parameter, sampling frequency, and method for collecting each sample - can be found in the individual permits, which are available to the public through SCDHEC's Freedom of Information Office at 803-734-5376. 
Table A-4

South Carolina Water Quality Standards for Freshwaters

Note: This is a partial list of water quality standards for freshwaters.

\title{
Parameters Standards
}

a. Fecal coliform Not to exceed a geometric mean of $200 / 100 \mathrm{~mL}$, based on five consecutive samples during any 30-day period; nor shall more than 10 percent of the total samples during any 30-day period exceed $400 / 100 \mathrm{~mL}$.

b. pH Range between 6.9 and 8.5

c. Temperature Generally, shall not be increased more than $5^{\circ} \mathrm{F}\left(2.8^{\circ} \mathrm{C}\right)$ above natural temperature conditions or be permitted to exceed a maximum of $90{ }^{\circ} \mathrm{F}\left(32.2^{\circ} \mathrm{C}\right)$ as a result of the discharge of heated liquids. For exceptions, see C.10, Regulation 61-68, "Water Classifications and Standards" (June 21, 2001).

d. Dissolved oxygen

Daily average not less than $5.0 \mathrm{mg} / \mathrm{L}$, with a low of $4.0 \mathrm{mg} / \mathrm{L}$.

e. Garbage, cinders, ashes, sludge, or other refuse

f. Treated wastes, toxic wastes, deleterious substances, colored or other wastes, except those in (e) above

\author{
g. Ammonia, chlorine, and toxic \\ pollutants listed in South Carolina \\ Regulation 61-68,“Water \\ Classifications and Standards"
}

None allowed.

None alone or in combination with other substances of wastes in sufficient amounts to make the waters unsafe or unsuitable for primary-contact recreation or to impair the waters for any other best usage as determined for the specific waters assigned to this class.

See Appendix: Water Quality Numeric Criteria for the Protection of Aquatic Life and Human Health, Regulation 6168,"Water Classifications and Standards" (June 21, 2001)

SOURCE: SCDHEC, 2001

\section{Site Streams}

SRS streams are classified as "Freshwaters" by South Carolina Regulation 61-69, "Classified Waters." Freshwaters are defined in Regulation 61-68, "Water Classifications and Standards," as surface water suitable for

- $\quad$ primary- and secondary-contact recreation and as a drinking water source after conventional treatment in accordance with SCDHEC requirements
- $\quad$ fishing and survival and propagation of a balanced indigenous aquatic community of fauna and flora

- $\quad$ industrial and agricultural uses

Table A-4 provides some of the specific guides used in water quality surveillance, but because some of these guides are not quantifiable, they are not tracked in response form (i.e., amount of garbage found).

\section{Savannah River}

Because the Savannah River is defined under South Carolina Regulation 61-69 as a freshwater system, the river is regulated in the same manner as are site streams (table A-4). 


\section{Drinking Water}

The federal Safe Drinking Water Act—enacted in 1974 to protect public drinking water supplies-was amended in 1980, 1986, and 1996.

SRS drinking water systems are tested routinely by SRS and SCDHEC to ensure compliance with SCDHEC State Primary Drinking Water Regulations (R61-58) and EPA National Primary Drinking Water Regulations (40 CFR 141).

SRS drinking water is supplied by 18 separate systems, all of which utilize groundwater sources. The three larger consolidated systems (A-Area, D-Area, and K-Area) are actively regulated by SCDHEC and are classified as nontransient/noncommunity systems because each serves more than 25 people. The remaining 15 site water systems, each of which serves fewer than 25 people, receive a lesser degree of regulatory oversight.

Under the SCDHEC-approved, ultrareduced monitoring plan, lead and copper sampling will not be required again for the A-Area consolidated system until 2004. The D-Area and K-Area consolidated water systems qualified in 1997 for an ultrareduced monitoring plan. Both D-Area and K-Area were sampled in 2003 for lead and copper, and neither stream exceeded the lead or copper action levels. These systems are not required to be sampled again until 2006.

The B-Area Bottled Water Facility, which was approved for operation in 1998, is listed as a public water system by SCDHEC and is required to be sampled quarterly for bacteriological analysis. Unlike the D-Area and K-Area consolidated water systems, lead and copper monitoring are not required.

DWS for specific radionuclides and contaminants can be found on the Internet at http://http://www.epa.gov/ safewater/mcl.html.

\section{Groundwater}

Groundwater is a valuable resource and is the subject of both protection and cleanup programs at SRS. More than 1,000 wells are monitored each year at the site for a wide range of constituents. Monitoring in the groundwater protection program is performed to detect new or unknown contamination across the site, and monitoring in the groundwater cleanup program is performed to meet the requirements of state and federal laws and regulations. Most of the monitoring in the cleanup program is governed by SCDHEC's administration of RCRA regulations.

The analytical results of samples taken from SRS monitoring wells are compared to various standards. The most common are final federal primary DWS-or other standards if DWS do not exist. The DWS are considered first because groundwater aquifers are defined as potential drinking water sources by the South Carolina Pollution Control Act. DWS can be found at http://www.epa.gov/safewater/mcl.html on the Internet. Other standards sometimes are applied by regulatory agencies to the SRS waste units under their jurisdiction. For example, standards under RCRA can include DWS, groundwater protection standards, background levels, or alternate concentration limits.

SRS responses to groundwater analytical results require careful evaluation of the data and relevant standards. Results from two constituents having
DWS-dichloromethane and bis (2-ethylhexyl) phthalate - are evaluated more closely than other constituents and are commonly dismissed. Both are common laboratory contaminants and are reported in groundwater samples with little or no reproducibility. Both are reported, with appropriate flags and qualifiers, in detailed groundwater monitoring results that can be obtained by contacting the manager of the Westinghouse Savannah River Company (WSRC) Environmental Monitoring and Analysis group at 803952-6931. Also, the standard used for lead, $50 \mu \mathrm{g} / \mathrm{L}$, is the SCDHEC DWS. The federal standard of $15 \mu \mathrm{g} / \mathrm{L}$ is a treatment standard for drinking water at the consumer's tap.

The regulatory standards for radionuclide discharges from industrial and governmental facilities are set under the Clean Water Act and Nuclear Regulatory Commission and DOE regulations. In addition, radionuclide cleanup levels are included in the site RCRA permit under the authority of the South Carolina Pollution Control Act. The proposed drinking water maximum contaminant levels discussed in this report are only an adjunct to these release restrictions and are not used to regulate SRS groundwater.

Many potential radionuclide contaminants are beta emitters. The standard used for gross beta is a screening standard; when public drinking water exceeds this 
standard, the supplier is expected to analyze for individual beta and gamma emitters. A gross beta result above the standard is an indication that one or more radioisotopes are present in quantities that would exceed the EPA annual dose equivalent for persons consuming 2 liters daily. Thus, for the individual beta and gamma radioisotopes (other than strontium-90 and tritium), the standard considered is the activity per liter that would, if only that isotope were present, exceed the dose equivalent. Similarly, the standards for alpha emitters are calculated to present the same risk at the same rate of ingestion.

The element radium has several isotopes of concern in groundwater monitoring. Although radium has a DWS of $5 \mathrm{pCi} / \mathrm{L}$ for the sum of radium-226 and radium-228, the isotopes have to be measured separately, and the combined numbers may not be representative of the total. Radium-226, an alpha emitter, and radium-228, a beta emitter, cannot be analyzed by a single method. Analyses for total alpha-emitting radium, which consists of radium-223, radium-224, and radium-226, are compared to the standard for radium-226.
Four other constituents without DWS are commonly used as indicators of potential contamination in wells. These constituents are

- $\quad$ specific conductance at values equal to or greater than $100 \mu \mathrm{S} / \mathrm{cm}$

- alkalinity (as $\mathrm{CaCO}_{3}$ ) at values equal to or greater than $100 \mathrm{mg} / \mathrm{L}$

- total dissolved solids (TDS) at values equal to or greater than $200 \mathrm{mg} / \mathrm{L}$

- $\quad \mathrm{pH}$ at values equal to or less than 4.0 or equal to or greater than 8.5 .

The selection of these values as standards for comparison is somewhat arbitrary; however, the values exceed levels usually found in background wells at SRS. The occurrence of elevated alkalinity (as $\mathrm{CaCO}_{3}$ ), specific conductance, $\mathrm{pH}$, and TDS within a single well also may indicate leaching of the grouting material used in well construction, rather than degradation of the groundwater.

\section{Potential Dose}

The radiation protection standards followed by SRS are outlined in DOE Order 5400.5 and include EPA regulations on the potential doses from airborne releases and treated drinking water.

The following radiation dose standards for protection of the public in the SRS vicinity are specified in DOE Order 5400.5:

Drinking Water Pathway .............. 4 mrem per year

Airborne Pathway 10 mrem per year

All Pathways 100 mrem per year

The EPA annual dose standard of 10 mrem $(0.1 \mathrm{mSv})$ for the atmospheric pathway, which is contained in 40 CFR 61, Subpart H, is adopted in DOE Order 5400.5.

These dose standards are based on recommendations of the ICRP and the National Council on Radiation Protection and Measurements.

The DOE dose standard enforced at SRS for drinking water is consistent with the criteria contained in "National Interim Primary Drinking Water Regula- tions, 40 CFR Part 141." Under these regulations, persons consuming drinking water shall not receive an annual whole body dose-DOE Order 5400.5 interprets this dose as committed effective dose equivalent-of more than 4 mrem $(0.04 \mathrm{mSv})$.

In 2000, EPA promulgated 40 CFR, Parts 9, 141, and 142, "National Primary Drinking Water Regulations; Radionuclides; Final Rule." This rule, which is applicable only to community drinking water systems, finalized maximum contaminant levels (MCLs) for radionuclides, including uranium. In essence, it reestablishes the MCLs from EPA's original 1976 rule. Most of these MCLs are derived from dose conversion factors that are based on early ICRP-2 methods.

However, when calculating dose, SRS must use the more current ICRP-30-based dose conversion factors provided by DOE. Because they are based on different methods, most EPA and DOE radionuclide dose conversion factors differ. Therefore, a direct comparison of the drinking water doses calculated for showing compliance with DOE Order 5400.5 to the EPA drinking water MCLs cannot be made. 


\section{Comparison of Average Concentrations in Airborne Emissions to DOE Derived Concentration Guides}

Average concentrations of radionuclides in airborne emissions are calculated by dividing the yearly release total of each radionuclide from each stack by the yearly stack flow quantities. These average concentrations then can be compared to the DOE DCGs, which are found in DOE Order 5400.5 for each radionuclide.

DCGs are used as reference concentrations for conducting environmental protection programs at all DOE sites. DCGs, which are based on a 100-mrem exposure, are applicable at the point of discharge (prior to dilution or dispersion) under conditions of continuous exposure (assumed to be an average inhalation rate of 8,400 cubic meters per year). This means that the DOE DCGs are based on the highly conservative assumption that a member of the public has direct access to and continuously breathes (or is immersed in) the actual air effluent 24 hours a day, 365 days a year. However, because of the large distance between most SRS operating facilities and the site boundary, this scenario is improbable.

Average annual radionuclide concentrations in SRS air effluent can be referenced to DOE DCGs as a screening method to determine if existing effluent treatment systems are proper and effective.

\section{Comparison of Average Concentrations in Liquid Releases to DOE Derived Concentration Guides}

In addition to dose standards, DOE Order 5400.5 imposes other control considerations on liquid releases. These considerations are applicable to direct discharges but not to seepage basin and Solid Waste Disposal Facility migration discharges. The DOE order lists DCG values for most radionuclides. DCGs are used as reference concentrations for conducting environmental protection programs at all DOE sites. These DCG values are not release limits but screening values for best available technology investigations and for determining whether existing effluent treatment systems are proper and effective.

Per DOE Order 5400.5, exceedance of the DCGs at any discharge point may require an investigation of best available technology waste treatment for the liquid effluents. Tritium in liquid effluents is specifically excluded from best available technology requirements; however, it is not excluded from other ALARA considerations. DOE DCG compliance is demonstrated when the sum of the fractional DCG values for all radionuclides detectable in the effluent is less than 1.00, based on consecutive 12-month average concentrations.

DCGs, based on a 100-mrem exposure, are applicable at the point of discharge from the effluent conduit to the environment (prior to dilution or dispersion). They are based on the highly conservative assumption that a member of the public has continuous direct access to the actual liquid effluents and consumes 2 liters of the effluents every day, 365 days a year. Because of security controls and the considerable distances between most SRS operating facilities and the site boundary, this scenario is highly improbable, if not impossible.

For each SRS facility that releases radioactivity, the site's Environmental Monitoring and Analysis group compares the monthly liquid effluent concentrations and 12-month average concentrations against the DOE DCGs.

\section{Environmental Management}

SRS began its cleanup program in 1981. Two major federal statutes provide guidance for the site's environmental restoration and waste management activities-RCRA and CERCLA. RCRA addresses the management of hazardous waste and requires that permits be obtained for facilities that treat, store, or dispose of hazardous or mixed waste. It also requires that DOE facilities perform appropriate corrective action to address contaminants in the environment. CERCLA (also known as Superfund) addresses the uncontrolled release of hazardous substances and the cleanup of inactive waste sites. This act establishes a National Priority List of sites targeted for assessment and, if necessary, corrective/remedial action. SRS was placed on this list December 21, 1989 [Fact Sheet, 2000]. In August 1993, SRS entered into the Federal 
Facility Agreement (FFA) with EPA Region IV and SCDHEC. This agreement governs the corrective/ remedial action process from site investigation through site remediation. It also describes procedures for setting annual work priorities, including schedules and deadlines, for that process [FFA under section 120 of CERCLA and sections 3008(h) and 6001 of RCRA].

Additionally, DOE is complying with Federal Facility Compliance Act requirements for mixed waste management - including high-level waste, most transuranic waste, and low-level waste with hazardous constituents. This act requires that DOE develop and submit site treatment plans to the EPA or state regulators for approval.

The disposition of facilities after they are declared excess to the government's mission is managed by Site Decommissioning and Demolition (D\&D)_formerly Facilities Disposition Projects. The facility disposition process is conducted in accordance with DOE Order 430.1A, "Life Cycle Asset Management," and its associated guidance documents. The major emphases are (1) to reduce the risks to workers, the public, and the environment, and (2) to reduce the costs required to maintain the facilities in a safe condition through a comprehensive surveillance and maintenance program.

\section{Quality Assurance/Quality Control}

DOE Order 414.1, "Quality Assurance," sets requirements and guidelines for departmental quality assurance (QA) practices. To ensure compliance with regulations and to provide overall quality requirements for site programs, WSRC developed its Quality Assurance Management Plan, Rev. 8 (WSRC-RP-92225). The plan's requirements are implemented by the WSRC Quality Assurance Manual (WSRC 1Q).

The SRS Environmental Monitoring Section Quality Assurance Plan (WSRC-3Q1-2, Volume 3, Section 8000 ), was written to apply the QA requirements of WSRC $1 \mathrm{Q}$ to the environmental monitoring and surveillance program. The EMA WSRC-3Q1 procedure series includes procedures on sampling, radiochemistry, and water quality that emphasize the quality control requirements for EMA.

QA requirements for monitoring radiological air emissions are specified in 40 CFR 61, "National Emission Standards for Hazardous Air Pollutants." For radiological air emissions at SRS, the responsibilities and lines of communication are detailed in National Emission Standards for Hazardous Air Pollutants Quality Assurance Project Plan (U) (WSRC-IM-9160).
To ensure valid and defensible monitoring data, the records and data generated by the monitoring program are maintained according to the requirements of DOE Guide 1324.5B, "Implementation Guide for Use with 36 CFR Chapter XII - Subchapter B Records Management," and of WSRC 1Q. QA records include sampling and analytical procedure manuals, logbooks, chain-of-custody forms, calibration and training records, analytical notebooks, control charts, validated laboratory data, and environmental reports. These records are maintained and stored per the requirements of WSRC Sitewide Records Inventory and Disposition Schedule (WSRC-1M-93-0060).

EMA assessments are implemented according to the following documents:

- $\quad$ DOE Order 414.1

- DOE/EH-0173T

- DOE Environmental Management Consolidated Audit Program (EMCAP)

- WSRC $1 \mathrm{Q}$

- WSRC 12Q, Assessment Manual

\section{Reporting}

DOE Orders 231.1, "Environment, Safety and Health Reporting," and 5400.5, "Radiation Protection of the Public and Environment," require that SRS submit an annual environmental report.

This report, the SRS Environmental Report for 2003, is an overview of effluent monitoring and environmen- tal surveillance activities conducted on and in the vicinity of SRS from January 1 through December 31, 2003. 


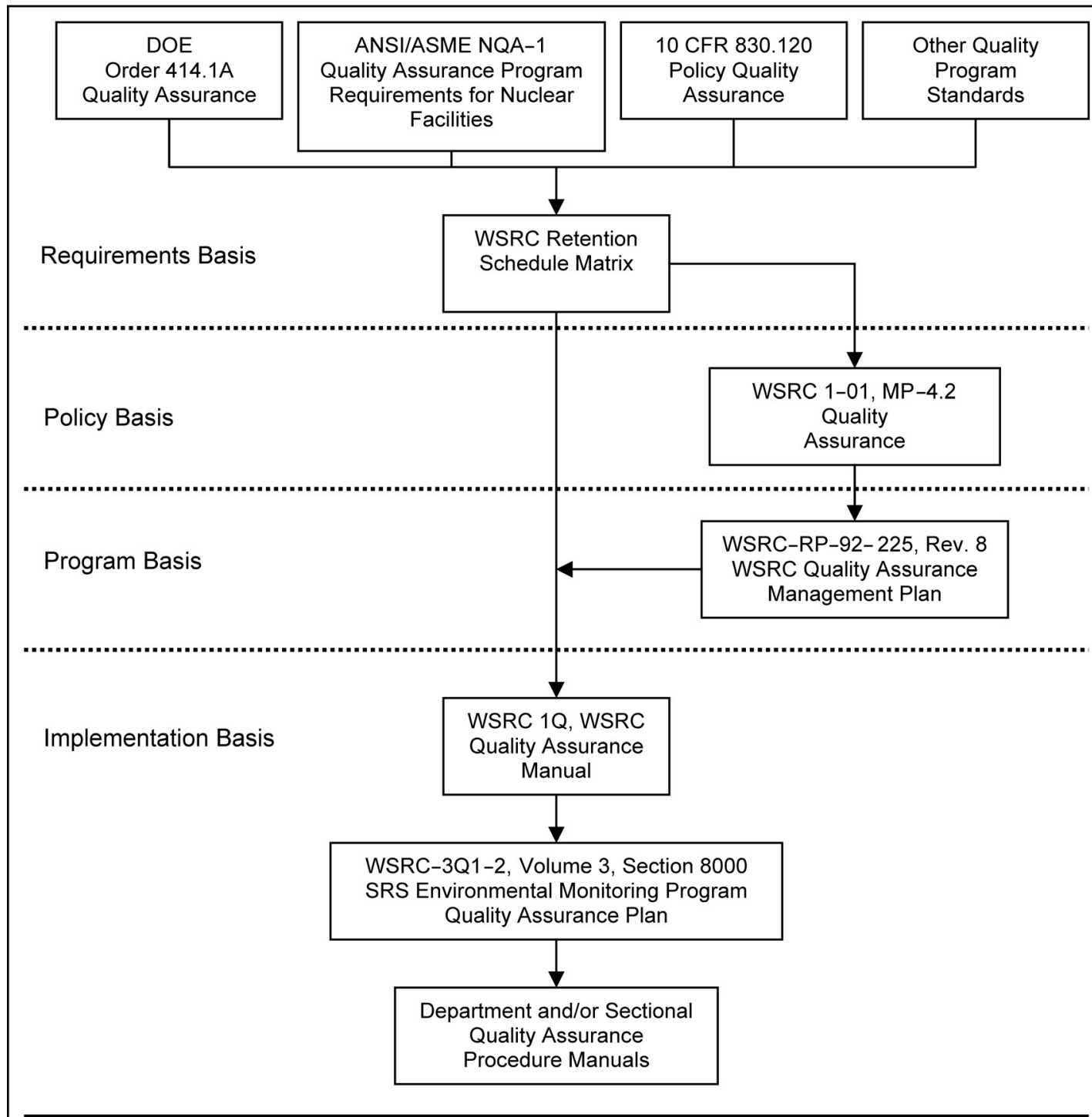

Other Quality Program Standards and Guidances

- ISO 1996

- ANSI 1995

- ISO 1999

Documents referenced in this figure are as follows:

-ANSI 1989

-WSRC 2001a

-DOE 2000

- DOE 2001a

-WSRC 2001b

-WSRC 1992

WSRC 2001j

-WSRC 2001I

Figure A-1 SRS EM Program QA/QC Document Hierarchy

This diagram depicts the hierarchy of relevant guidance and supporting documents for the QA/QC program. 


\section{ISO 14001 Environmental Management System}

ISO 14001 is the EMS standard within the ISO 14000 series of standards, a family of voluntary environmental management standards and guidelines. SRS first achieved ISO 14001 independent certification of its EMS against this standard in 1997 by demonstrating adherence to and programmatic implementation of the SRS Environmental Management System Policy.
Beginning in May 2002, the site discontinued independent certification of its EMS program, but it continues to self-evaluate itself against the ISO 14001 standard. A requirement of the standard is maintenance of an environmental policy. The full text of the policy follows.

\section{Environmental Management System Policy} June 16, 2003

\section{Objective}

The management of the Savannah River Site (SRS) recognize its responsibility to conduct its operations in compliance with applicable laws and regulations providing for the protection of the environment, to reduce the use of procedures and processes that produce hazardous wastes, and to seek ways to continually improve the performance of activities protective of the environment.

\section{Directive}

Recognizing that many aspects of operations carried out at SRS may impact the environment, the SRS policy is that all employees, contractors, subcontractors, and other entities performing work at SRS shall abide by the directives in this document. This document serves as the primary documentation for the environmental goals and objectives of SRS and shall be available to the public. It shall be centrally maintained and updated as necessary to reflect the changing needs, missions, visions, and goals of SRS. The U.S. Department of Energy-Savannah River Operations Office (DOE-SR), Westinghouse Savannah River Company, Wackenhut Services Inc.Savannah River Site, Savannah River Ecology Laboratory, General Services Administration-Savannah River Site, National Nuclear Security Administration-Savannah River Site (NNSA-SRS), and United States Forest Service-Savannah River endorse the principles stated in this policy.

- The Environmental Management System pursues and measures continual improvement in performance by establishing and maintaining documented environmental objectives and targets that correspond to SRS's mission, vision, and core values. The environmental objectives and targets shall be established for each relevant function within DOE-SR, NNSA-SRS, and all contractors, subcontractors, and other entities performing work at SRS for all activities having actual or potentially significant environmental impacts.

- DOE-SR, NNSA-SRS, and all contractors, subcontractors, and other entities performing work at SRS shall

1. manage the SRS environment, natural resources, products, waste, and contaminated materials so as to eliminate or mitigate any threat to human health or the environment at the earliest opportunity and implement process improvements, as appropriate, to ensure continual improvement of performance in environmental management

2. implement a pollution prevention program to reduce waste generation, releases of pollutants, and future waste management and pollution control costs, and to promote energy efficiency

3. conduct operations in compliance with all applicable federal, state, and local laws, regulations, statutes, executive orders, directives, and standards

4. work cooperatively and openly with appropriate local, state, and federal agencies, public stakeholders, and site employees to prevent pollution, achieve environmental compliance, conduct cleanup and restoration activities, enhance environmental quality, and ensure the protection of workers and the public 
5. design, develop, operate, maintain, decommission, and deactivate facilities and perform operations in a manner that shall be resource efficient and will protect and improve the quality of the environment for future generations, and continue to maintain SRS as a unique national environmental asset

6. recognize that the responsibility for quality communications rests with each individual employee and that it shall be the responsibility of all employees to identify and communicate ideas for improving environmental protection activities and programs at the site

Adherence to and programmatic implementation of this policy shall be the responsibility of DOE-SR, NNSASRS, and the Office of Fissile Materials Disposition managers in coordination with the contractors, subcontractors, and other entities performing work at SRS.

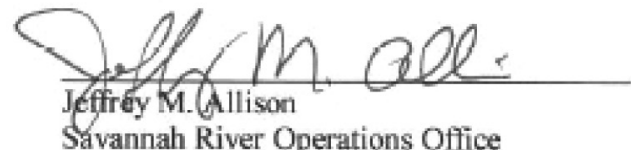

Savannah River Operations Office

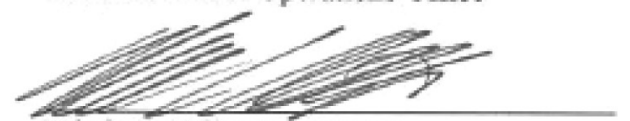

Edwin L. Wilmot, Manager

Savannah River Site Office, NNSA-SRS

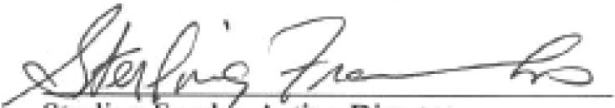

Sterling Franks, Acting Director

Fissile Matenals Dispogrion Office, NNSA-SRS

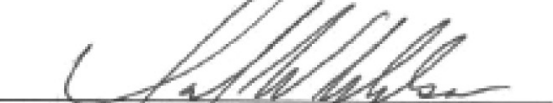

David W. Wilson, Forest Manager

U. S. Forest Service - Savannah River

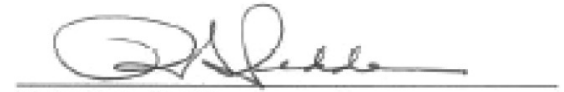

Robert A. Pedde

Westinghouse Savannah River Company LLC

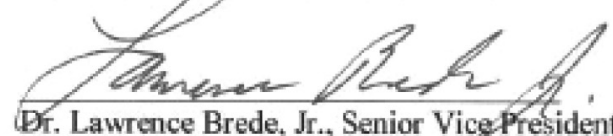

Dr. Lawrence Brede, Jr., Senior Vice Presiden and General Manager, WSI-SRS

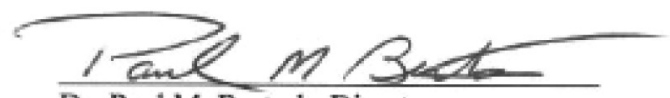

Dr. Paul M. Bertsch, Director

Savannah River Ecology Laboratory

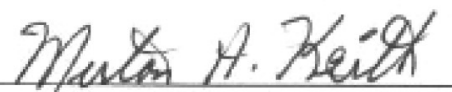

Merton A. Keith, Environmental Manager, GSA-SRS 



\section{Appendix B \\ Radionuclide and Chemical \\ Nomenclature}

\begin{tabular}{|c|c|c|c|c|c|}
\hline \multicolumn{6}{|c|}{ Nomenclature and Half-Life for Radionuclides } \\
\hline Radionuclide & Symbol & Half-life $e^{a, b}$ & Radionuclide & Symbol & Half-life $e^{a, b}$ \\
\hline Actinium-228 & Ac-228 & $6.15 \mathrm{~h}$ & Mercury-203 & $\mathrm{Hg}-203$ & $46.61 \mathrm{~d}$ \\
\hline Americium-241 & Am-241 & 432.7 y & Neptunium-237 & Np-237 & 2.14E6 y \\
\hline Americium-243 & Am-243 & 7370 y & Neptunium-239 & Np-239 & $2.355 d$ \\
\hline Antimony-124 & Sb-124 & $60.2 \mathrm{~d}$ & Nickel-59 & $\mathrm{Ni}-59$ & 7.6E4 y \\
\hline Antimony-125 & Sb-125 & 2.758 y & Nickel-63 & $\mathrm{Ni}-63$ & $100 y$ \\
\hline Argon-39 & Ar-39 & 269 y & Niobium-94 & $\mathrm{Nb}-94$ & $2.0 \mathrm{E} 4 \mathrm{y}$ \\
\hline Barium-133 & Ba-133 & $10.7 y$ & Niobium-95 & $\mathrm{Nb}-95$ & $34.97 \mathrm{~d}$ \\
\hline Beryllium-7 & $\mathrm{Be}-7$ & $53.28 d$ & Plutonium-238 & Pu-238 & $87.7 y$ \\
\hline Bismuth-212 & $\mathrm{Bi}-212$ & $2.14 \mathrm{~m}$ & Plutonium-239 & Pu-239 & $2.41 E 4 y$ \\
\hline Bismuth-214 & $\mathrm{Bi}-214$ & $19.9 \mathrm{~m}$ & Plutonium-240 & Pu-240 & $6560 \mathrm{y}$ \\
\hline Carbon-14 & C-14 & 5714 y & Plutonium-241 & Pu-241 & $14.4 \mathrm{y}$ \\
\hline Cerium-141 & Ce-141 & $32.5 \mathrm{~d}$ & Plutonium-242 & Pu-242 & 3.75E5 y \\
\hline Cerium-144 & Ce-144 & $284.6 \mathrm{~d}$ & Potassium-40 & $\mathrm{K}-40$ & 1.27E9 $y$ \\
\hline Cesium-134 & Cs-134 & $2.065 \mathrm{y}$ & Praseodymium-144 & Pr-144 & $17.28 \mathrm{~m}$ \\
\hline Cesium-137 & Cs-137 & 30.07 y & Praseodymium $-144 \mathrm{~m}$ & Pr- $144 m$ & $7.2 \mathrm{~m}$ \\
\hline Chromium-51 & Cr-51 & $27.702 \mathrm{~d}$ & Promethium-147 & $\mathrm{Pm}-147$ & $2.6234 \mathrm{y}$ \\
\hline Cobalt-57 & Co-57 & $271.8 d$ & Protactinium-231 & $\mathrm{Pa}-231$ & $3.28 E 4$ y \\
\hline Cobalt-58 & Co-58 & $70.88 d$ & Protactinium-233 & $\mathrm{Pa}-233$ & $27.0 \mathrm{~d}$ \\
\hline Cobalt-60 & Co-60 & $5.271 \mathrm{y}$ & Protactinium-234 & $\mathrm{Pa}-234$ & $6.69 \mathrm{~h}$ \\
\hline Curium-242 & $\mathrm{Cm}-242$ & $162.8 d$ & Radium-226 & Ra-226 & 1599 y \\
\hline Curium-244 & $\mathrm{Cm}-244$ & $18.1 \mathrm{y}$ & Radium-228 & $\mathrm{Ra}-228$ & $5.76 \mathrm{y}$ \\
\hline Curium-245 & $\mathrm{Cm}-245$ & 8.50E3 y & Ruthenium-103 & Ru-103 & $39.27 \mathrm{~d}$ \\
\hline Curium-246 & $\mathrm{Cm}-246$ & 4.76E3 y & Ruthenium-106 & Ru-106 & $1.020 \mathrm{y}$ \\
\hline Europium-152 & Eu-152 & $13.54 \mathrm{y}$ & Selenium-75 & Se-75 & $119.78 \mathrm{~d}$ \\
\hline Europium-154 & Eu-154 & 8.593 y & Selenium-79 & Se-79 & $6.5 \mathrm{E} 5 \mathrm{y}$ \\
\hline Europium-155 & Eu-155 & $4.75 y$ & Sodium-22 & $\mathrm{Na}-22$ & $2.604 \mathrm{y}$ \\
\hline lodine-129 & $\mathrm{I}-129$ & 1.57E7 y & Strontium-89 & Sr-89 & $50.52 \mathrm{~d}$ \\
\hline lodine-131 & $\mathrm{I}-131$ & $8.0207 \mathrm{~d}$ & Strontium-90 & Sr-90 & $28.78 \mathrm{y}$ \\
\hline lodine-133 & $\mathrm{I}-133$ & $20.3 \mathrm{~h}$ & Technetium-99 & Tc-99 & $2.13 E 5 y$ \\
\hline Krypton-85 & $\mathrm{Kr}-85$ & $10.76 \mathrm{y}$ & Thallium-208 & TI-208 & $3.053 \mathrm{~m}$ \\
\hline Lead-212 & $\mathrm{Pb}-212$ & $10.64 \mathrm{~h}$ & Thorium-228 & Th-228 & $1.913 y$ \\
\hline Lead-214 & $\mathrm{Pb}-214$ & $27 \mathrm{~m}$ & Thorium-230 & Th-230 & 7.54E4 y \\
\hline Manganese-54 & $\mathrm{Mn}-54$ & $312.1 \mathrm{~d}$ & Thorium-232 & Th-232 & $1.40 \mathrm{E} 10 \mathrm{y}$ \\
\hline
\end{tabular}

a $m=$ minute; $h=$ hour; $d=$ day; $y=$ year

b Reference: Chart of the Nuclides, 15th edition, revised 1996, General Electric Company 
Nomenclature and Half-Life for Radionuclides, Continued

\begin{tabular}{llcllr} 
Radionuclide & Symbol & Half-life $^{\text {a,b }}$ & Radionuclide & Symbol & Half-life $^{\text {a,b }}$ \\
\hline Thorium-234 & Th-234 & $24.10 \mathrm{~d}$ & Uranium-235 & U-235 & $7.04 \mathrm{E} 8 \mathrm{y}$ \\
Tin-113 & $\mathrm{Sn}-113$ & $115.1 \mathrm{~d}$ & Uranium-236 & $\mathrm{U}-236$ & $2.342 \mathrm{E} 7 \mathrm{y}$ \\
Tin-126 & $\mathrm{Sn}-126$ & $2.5 \mathrm{E} 5 \mathrm{y}$ & Uranium-238 & $\mathrm{U}-238$ & $4.47 \mathrm{E} 9 \mathrm{y}$ \\
Tritium (Hydrogen-3) & $\mathrm{H}-3$ & $12.32 \mathrm{y}$ & Xenon-135 & $\mathrm{Xe}-135$ & $9.10 \mathrm{~h}$ \\
Uranium-232 & $\mathrm{U}-232$ & $69.8 \mathrm{y}$ & Zinc-65 & Zn-65 & $243.8 \mathrm{~d}$ \\
Uranium-233 & $\mathrm{U}-233$ & $1.592 \mathrm{E} 5 \mathrm{y}$ & Zirconium-85 & Zr-85 & $7.7 \mathrm{~m}$ \\
Uranium-234 & $\mathrm{U}-234$ & $2.46 \mathrm{E} 5 \mathrm{y}$ & Zirconium-95 & Zr-95 & $64.02 \mathrm{~d}$
\end{tabular}

a $\mathrm{m}=$ minute; $\mathrm{h}=$ hour; $\mathrm{d}=$ day; $\mathrm{y}=$ year

b Reference: Chart of the Nuclides, 15th edition, revised 1996, General Electric Company 


\section{Nomenclature for Elements and Chemical Constituent Analyses}

Constituent Symbol Constituent Symbol

Note: $\quad$ Some of the symbols listed in this table came from various databases used to format the data tables in this report and are included here to assist the reader in understanding the tables.

\begin{tabular}{|c|c|c|c|}
\hline Aluminum & $\mathrm{Al}$ (or $\mathrm{AL})$ & Nitrite, Nitrate & $\begin{array}{l}\mathrm{NO} 2, \mathrm{NO} 3 \text { (or } \mathrm{NO}_{2} \\
\left.\mathrm{NO}_{3} \text { or } \mathrm{NO} / \mathrm{NO}_{3}\right)\end{array}$ \\
\hline Ammonia & $\mathrm{NH}_{3}$ & & $\mathrm{NO}_{3}$ or $\left.\mathrm{NO} 2 / \mathrm{NO} 3\right)$ ) \\
\hline Ammonia as Nitrogen & $\mathrm{NH}_{3}-\mathrm{N}($ or $\mathrm{AN})$ & $\mathrm{pH}$ & $\mathrm{pH}$ (orPH) \\
\hline Antimony & $\mathrm{Sb}$ (or SB) & Phenol & PHE \\
\hline Arsenic & As (or AS) & Phosphorus & $\mathrm{P}$ \\
\hline Barium & $\mathrm{Ba}$ (or $\mathrm{BA})$ & Phosphate & $\mathrm{PO}_{4}$ (or PO4-P or \\
\hline Biological Oxygen Demand & BOD & & $\left.\mathrm{PO}_{4}^{-} \mathrm{P}\right)$ \\
\hline Beryllium & $\mathrm{Be}$ & Polychlorinated Biphenyl & PCB \\
\hline Boron & $\mathrm{B}$ & Potassium & $\mathrm{K}$ \\
\hline Bromine & $\mathrm{Br}$ & Selenium & Se (or SE) \\
\hline Cadmium & $\mathrm{Cd}($ or CD) & Silver & $\mathrm{Ag}(\operatorname{or} \mathrm{AG})$ \\
\hline Chemical Oxygen Demand & COD & Sulfate & $\mathrm{SO}_{4}($ or SO 4$)$ \\
\hline Chlorine & $\mathrm{Cl}$ (or $\mathrm{CHL})$ & Tetrachloroethene & PERCL \\
\hline Chromium & $\mathrm{Cr}$ (or CR) & Tetrachloroethylene & \\
\hline Cobalt & Co & (Perchloroethylene) & PERCL \\
\hline Copper & $\mathrm{Cu}$ (or CU) & Trichloroethene & TRICL \\
\hline Cyanide & $\mathrm{CN}$ & Trichloroethylene & TRICL \\
\hline Dissolved Oxygen & DO & Tin & SN \\
\hline Iron & $\mathrm{Fe}$ (or FE) & Total Dissolved Solids & TDS \\
\hline Lead & $\mathrm{Pb}$ (or PB) & Total Kjeldahl Nitrogen & TKN \\
\hline Magnesium & $\mathrm{Mg}$ (or $\mathrm{MG})$ & Total Organic Carbon & TOC \\
\hline Manganese & $\mathrm{Mn}$ (or MN) & Total Suspended Particulate & TSP \\
\hline Mercury & $\mathrm{Hg}$ (or HG) & Matter & \\
\hline Molybdenum & Mo & Total Suspended Solids & TSS \\
\hline Nickel & $\mathrm{Ni}($ or $\mathrm{NI})$ & Total Volatile Solids & TVS \\
\hline Nitrate & $\mathrm{NO}_{3}$ & Uranium & $U$ \\
\hline Nitrate as Nitrogen & $\mathrm{NO}_{3-} \mathrm{N}$ & Vinyl Chloride & VC \\
\hline Nitrite as Nitrogen & $\mathrm{NO}_{2-} \mathrm{N}$ & Zinc & $\mathrm{Zn}($ or $\mathrm{ZN})$ \\
\hline
\end{tabular}





\section{Glossary}

A

accuracy - Closeness of the result of a measurement to the true value of the quantity.

actinide - Group of elements of atomic number 89 through 103. Laboratory analysis of actinides by alpha spectrometry generally refers to the elements plutonium, americium, uranium, and curium but may also include neptunium and thorium.

activity - See radioactivity.

air flow - Rate of flow, measured by mass or volume per unit of time.

air stripping - Process used to decontaminate groundwater by pumping the water to the surface, "stripping" or evaporating the chemicals in a specially designed tower, and pumping the cleansed water back to the environment.

aliquot - Quantity of sample being used for analysis.

alkalinity - Alkalinity is a measure of the buffering capacity of water, and since $\mathrm{pH}$ has a direct effect on organisms as well as an indirect effect on the toxicity of certain other pollutants in the water, the buffering capacity is important to water quality.

alpha particle - Positively charged particle emitted from the nucleus of an atom having the same charge and mass as that of a helium nucleus (two protons and two neutrons).

ambient air - Surrounding atmosphere as it exists around people, plants, and structures.

analyte - Constituent or parameter that is being analyzed.

analytical detection limit - Lowest reasonably accurate concentration of an analyte that can be detected; this value varies depending on the method, instrument, and dilution used.

aquifer - Saturated, permeable geologic unit that can transmit significant quantities of water under ordinary hydraulic gradients. aquitard - Geologic unit that inhibits the flow of water.

Atomic Energy Commission - Federal agency created in 1946 to manage the development, use, and control of nuclear energy for military and civilian application. It was abolished by the Energy Reorganization Act of 1974 and succeeded by the Energy Research and Development Administration. Functions of the Energy Research and Development Administration eventually were taken over by the U.S. Department of Energy and the U.S. Nuclear Regulatory Commission.

B

background radiation - Naturally occurring radiation, fallout, and cosmic radiation. Generally, the lowest level of radiation obtainable within the scope of an analytical measurement, i.e., a blank sample.

bailer - Container lowered into a well to remove water. The bailer is allowed to fill with water and then is removed from the well.

best management practices - Sound engineering practices that are not required by regulation or by law.

beta particle - Negatively charged particle emitted from the nucleus of an atom. It has a mass and charge equal to those of an electron.

blank - Control sample that is identical, in principle, to the sample of interest, except that the substance being analyzed is absent. In such cases, the measured value or signal for the substance being analyzed is believed to be due to artifacts. Under certain circumstances, that value may be subtracted from the measured value to give a net result reflecting the amount of the substance in the sample. The U.S. Environmental Protection Agency does not permit the subtraction of blank results in Environmental Protection Agency-regulated analyses.

blind blank - Sample container of deionized water sent to a laboratory under an alias name as a quality control check. 
blind replicate - In the Environmental Services Section groundwater monitoring program, a second sample taken from the same well at the same time as the primary sample, assigned an alias well name, and sent to a laboratory for analysis (as an unknown to the analyst).

blind sample - Control sample of known concentration in which the expected values of the constituent are unknown to the analyst.

C

calibration - Process of applying correction factors to equate a measurement to a known standard. Generally, a documented measurement control program of charts, graphs, and data that demonstrate that an instrument is properly calibrated.

Carolina bay - Type of shallow depression commonly found on the coastal Carolina plains. Carolina bays are typically circular or oval. Some are wet or marshy, while others are dry.

Central Savannah River Area (CSRA) - Eighteencounty area in Georgia and South Carolina surrounding Augusta, Georgia. The Savannah River Site is included in the Central Savannah River Area. Counties are Richmond, Columbia, McDuffie, Burke, Emanuel, Glascock, Jenkins, Jefferson, Lincoln, Screven, Taliaferro, Warren, and Wilkes in Georgia and Aiken, Edgefield, Allendale, Barnwell, and McCormick in South Carolina.

chemical oxygen demand - Indicates the quantity of oxidizable materials present in a water and varies with water composition, concentrations of reagent, temperature, period of contact, and other factors.

chlorocarbons - Compounds of carbon and chlorine, or carbon, hydrogen, and chlorine, such as carbon tetrachloride, chloroform, tetrachloroethylene, etc. They are among the most significant and widespread environmental contaminants. Classified as hazardous wastes, chlorocarbons may have a tendency to cause detrimental effects, such as birth defects.

cleanup - Actions taken to deal with release or potential release of hazardous substances. This may mean complete removal of the substance; it also may mean stabilizing, containing, or otherwise treating the substance so that it does not affect human health or the environment. closure - Control of a hazardous waste management facility under Resource Conservation and Recovery Act requirements.

compliance - Fulfillment of applicable requirements of a plan or schedule ordered or approved by government authority.

composite - Blending of more than one portion to make a sample for analysis.

Comprehensive Environmental Response, Compensation, and Liability Act (CERCLA) - This act addresses the cleanup of hazardous substances and establishes a National Priorities List of sites targeted for assessment and, if necessary, restoration (commonly known as "Superfund").

\section{Comprehensive Environmental Response, Compensation, and Liability Act} (CERCLA)-reportable release - Release to the environment that exceeds reportable quantities as defined by the Comprehensive Environmental Response, Compensation, and Liability Act.

concentration - Amount of a substance contained in a unit volume or mass of a sample.

conductivity - Measure of water's capacity to convey an electric current. This property is related to the total concentration of the ionized substances in a water and the temperature at which the measurement is made.

contamination - State of being made impure or unsuitable by contact or mixture with something unclean, bad, etc.

count - Signal that announces an ionization event within a counter; a measure of the radiation from an object or device.

counting geometry - Well-defined sample size and shape for which a counting system has been calibrated.

criteria pollutant - Any of the pollutants commonly used as indices for air quality that can have a serious effect on human health and the environment, including sulfur dioxide, nitrogen dioxide, total suspended particulates, $\mathrm{PM}_{10}$ carbon monoxide, ozone, gaseous fluorides, and lead.

curie - Unit of radioactivity. One curie is defined as $3.7 \times 10^{10}$ (37 billion) disintegrations per second. Several fractions and multiples of the curie are commonly used: 
kilocurie (kCi) - $10^{3} \mathrm{Ci}$, one thousand curies; $3.7 \mathrm{x}$ $10^{13}$ disintegrations per second.

millicurie (mCi) - $10^{-3} \mathrm{Ci}$, one-thousandth of a curie; $3.7 \times 10^{7}$ disintegrations per second.

microcurie $(\mu \mathrm{Ci})-10^{-6} \mathrm{Ci}$, one-millionth of a curie; $3.7 \times 10^{4}$ disintegrations per second.

picocurie (pCi) - $10^{-12} \mathrm{Ci}$, one-trillionth of a curie; 0.037 disintegrations per second.

D

decay (radioactive) - Spontaneous transformation of one radionuclide into a different radioactive or nonradioactive nuclide, or into a different energy state of the same radionuclide.

decay time - Time taken by a quantity to decay to a stated fraction of its initial value.

deactivation - The process of placing a facility in a stable and known condition, including the removal of hazardous and radioactive materials to ensure adequate protection of the worker, public health and safety, and the environment- - thereby limiting the long-term cost of surveillance and maintenance.

decommissioning - Process that takes place after deactivation and includes surveillance and maintenance, decontamination, and/or dismantlement.

decontamination - The removal or reduction of residual radioactive and hazardous materials by mechanical, chemical, or other techniques to achieve a stated objective or end condition.

decommissioning and demolition - Program that reduces the environmental and safety risks of surplus facilities at SRS.

derived concentration guide - Concentration of a radionuclide in air or water that, under conditions of continuous exposure for one year by one exposure mode (i.e., ingestion of water, submersion in air, or inhalation), would result in either an effective dose equivalent of $0.1 \mathrm{rem}(1 \mathrm{mSv})$ or a dose equivalent of $5 \mathrm{rem}(50 \mathrm{mSv})$ to any tissue, including skin and lens of the eye. The guides for radionuclides in air and water are given in U.S. Department of Energy Order 5400.5 .

detection limit - See analytical detection limit, lower limit of detection, minimum detectable concentration. detector - Material or device (instrument) that is sensitive to radiation and can produce a signal suitable for measurement or analysis.

diatometer - Diatom collection equipment consisting of a series of microscope slides in a holder that is used to determine the amount of algae in a water system.

diatoms - Unicellular or colonial algae of the class Bacillariophyceae, having siliceous cell walls with two overlapping, symmetrical parts. Diatoms represent the predominant periphyton (attached algae) in most water bodies and have been shown to be reliable indicators of water quality.

disposal - Permanent or temporary transfer of U.S. Department of Energy control and custody of real property to a third party, which thereby acquires rights to control, use, or relinquish the property.

disposition - Those activities that follow completion of program mission-including, but not limited to, surveillance and maintenance, deactivation, and decommissioning.

dissolved oxygen - Desirable indicator of satisfactory water quality in terms of low residuals of biologically available organic materials. Dissolved oxygen prevents the chemical reduction and subsequent leaching of iron and manganese from sediments.

dose - Energy imparted to matter by ionizing radiation. The unit of absorbed dose is the rad, equal to 0.01 joules per kilogram in any medium.

absorbed dose - Quantity of radiation energy absorbed by an organ, divided by the organ's mass. Absorbed dose is expressed in units of rad (or gray) (1 $\mathrm{rad}=0.01 \mathrm{~Gy})$.

dose equivalent - Product of the absorbed dose (rad) in tissue and a quality factor. Dose equivalent is expressed in units of rem (or sievert) $(1 \mathrm{rem}=$ 0.01 sievert).

committed dose equivalent - Calculated total dose equivalent to a tissue or organ over a 50-year period after known intake of a radionuclide into the body. Contributions from external dose are not included. Committed dose equivalent is expressed in units of rem (or sievert).

committed effective dose equivalent - Sum of the committed dose equivalents to various tissues in the body, each multiplied by the appropriate weighting factor. Committed effective dose equivalent is expressed in units of rem (or sievert). 
effective dose equivalent - Sum of the dose equivalents received by all organs or tissues of the body after each one has been multiplied by an appropriate weighting factor. The effective dose equivalent includes the committed effective dose equivalent from internal deposition of radionuclides and the effective dose equivalent attributable to sources external to the body.

\section{collective dose equivalent/collective effective} dose equivalent - Sums of the dose equivalents or effective dose equivalents of all individuals in an exposed population within a $50-$ mile $(80-\mathrm{km})$ radius, and expressed in units of person-rem (or person-sievert). When the collective dose equivalent of interest is for a specific organ, the units would be organ-rem (or organ-sievert). The 50-mile distance is measured from a point located centrally with respect to major facilities or U.S. Department of Energy program activities.

dosimeter - Portable detection device for measuring the total accumulated exposure to ionizing radiation.

downgradient - In the direction of decreasing hydrostatic head.

drinking water standards - Federal primary drinking water standards, both proposed and final, as set forth by the U.S. Environmental Protection Agency.

duplicate result - Result derived by taking a portion of a primary sample and performing the identical analysis on that portion as is performed on the primary sample.

E

effluent - Any treated or untreated air emission or liquid discharge to the environment.

effluent monitoring - Collection and analysis of samples or measurements of liquid and gaseous effluents for purpose of characterizing and quantifying the release of contaminants, assessing radiation exposures of members to the public, and demonstrating compliance with applicable standards.

environmental compliance - Actions taken in accordance with government laws, regulations, orders, etc., that apply to site operations' effects on onsite and offsite natural resources and on human health; used interchangeably in this document with regulatory compliance. environmental monitoring - Program at Savannah River Site that includes effluent monitoring and environmental surveillance with dual purpose of (1) showing compliance with federal, state, and local regulations, as well as with U.S. Department of Energy orders, and (2) monitoring any effects of site operations on onsite and offsite natural resources and on human health.

environmental restoration - U.S. Department of Energy program that directs the assessment and cleanup of inactive waste units and groundwater (remediation) contaminated as a result of nuclearrelated activities.

environmental surveillance - Collection and analysis of samples of air, water, soil, foodstuffs, biota, and other media from U.S. Department of Energy sites and their environs and the measurement of external radiation for purpose of demonstrating compliance with applicable standards, assessing radiation exposures to members of the public, and assessing effects, if any, on the local environment.

exceedance - Term used by the U.S. Environmental Protection Agency and the South Carolina Department of Health and Environmental Control that denotes a report value is more than the upper guide limit. This term is found on the discharge monitoring report forms that are submitted to the Environmental Protection Agency or the South Carolina Department of Health and Environmental Control.

exposure (radiation) - Incidence of radiation on living or inanimate material by accident or intent. Background exposure is the exposure to natural background ionizing radiation. Occupational exposure is that exposure to ionizing radiation that takes place during a person's working hours. Population exposure is the exposure to the total number of persons who inhabit an area.

exposure pathway - Route that materials follow to get to the environment and then to people.

fallout - See worldwide fallout.

Federal Facility Agreement (FFA) - Agreement negotiated among the U.S. Department of Energy, the U.S. Environmental Protection Agency, and the South Carolina Department of Health and Environmental Control, specifying how the Savannah River Site will 
address contamination or potential contamination to meet regulatory requirements at Savannah River Site waste units identified for evaluation and, if necessary, cleanup.

feral hog - Hog that has reverted to the wild state from domestication.

\section{G}

gamma ray - High-energy, short-wavelength electromagnetic radiation emitted from the nucleus of an excited atom. Gamma rays are identical to X-rays except for the source of the emission.

gamma-emitter - Any nuclide that emits a gamma ray during the process of radioactive decay. Generally, the fission products produced in nuclear reactors.

gamma spectrometry - System consisting of a detector, associated electronics, and a multichannel analyzer that is used to analyze samples for gammaemitting radionuclides.

grab sample - Sample collected instantaneously with a glass or plastic bottle placed below the water surface to collect surface water samples (also called dip samples).

\section{H}

half-life (radiological) - Time required for half of a given number of atoms of a specific radionuclide to decay. Each nuclide has a unique half-life.

heavy water - Water in which the molecules contain oxygen and deuterium, an isotope of hydrogen that is heavier than ordinary hydrogen.

hydraulic gradient - Difference in hydraulic head over a specified distance.

hydrology - Science that treats the occurrence, circulation, distribution, and properties of the waters of the earth, and their reaction with the environment.

in situ - In its original place. Field measurements taken without removing the sample from its origin; remediation performed while groundwater remains below the surface. inorganic - Involving matter other than plant or animal.

instrument background - Instrument signal due to electrical noise and other interferences not attributed to the sample or blank.

ion exchange - Process in which a solution containing soluble ions is passed over a solid ion exchange column that removes the soluble ions by exchanging them with labile ions from the surface of the column. The process is reversible so that the trapped ions are removed (eluted) from the column and the column is regenerated.

irradiation - Exposure to radiation.

isotopes - Forms of an element having the same number of protons in their nuclei but differing in the number of neutrons.

long-lived isotope - Radionuclide that decays at such a slow rate that a quantity of it will exist for an extended period (half-life is greater than three years).

short-lived isotope - Radionuclide that decays so rapidly that a given quantity is transformed almost completely into decay products within a short period (half-life is two days or less).

laboratory blank - Deionized water sample generated by the laboratory; a laboratory blank is analyzed with each batch of samples as an in-house check of analytical procedures. Also called an internal blank.

legacy - Anything handed down from the past; inheritance, as of nuclear waste.

lower limit of detection - Smallest concentration/ amount of an analyte that can be reliably detected in a sample at a 95-percent confidence level.

$\mathbf{M}$

macroinvertebrates - Size-based classification used for a variety of insects and other small invertebrates; as defined by the U.S. Environmental Protection Agency, those organisms that are retained by a No. 30 (590-micron) U.S. Standard Sieve.

macrophyte - A plant that can be observed with the naked eye. 
manmade radiation - Radiation from sources such as consumer products, medical procedures, and nuclear industry.

maximally exposed individual - Hypothetical individual who remains in an uncontrolled area and would, when all potential routes of exposure from a facility's operations are considered, receive the greatest possible dose equivalent.

mean relative difference - Percentage error based on statistical analysis.

mercury - Silver-white, liquid metal solidifying at $-38.9^{\circ} \mathrm{C}$ to form a tin-white, ductile, malleable mass. It is widely distributed in the environment and biologically is a nonessential or nonbeneficial element. Human poisoning due to this highly toxic element has been clinically recognized.

migration - Transfer or movement of a material through the air, soil, or groundwater.

minimum detectable concentration - Smallest amount or concentration of a radionuclide that can be distinguished in a sample by a given measurement system at a preselected counting time and at a given confidence level.

moderate - To reduce the excessiveness of; to act as a moderator.

moderator - Material, such as heavy water, used in a nuclear reactor to moderate or slow down neutrons from the high velocities at which they are created in the fission process.

monitoring - Process whereby the quantity and quality of factors that can affect the environment and/ or human health are measured periodically to regulate and control potential impacts.

nonroutine radioactive release - Unplanned or nonscheduled release of radioactivity to the environment.

nuclide - Atom specified by its atomic weight, atomic number, and energy state. A radionuclide is a radioactive nuclide.
0

opacity - The reduction in visibility of an object or background as viewed through the diameter of a plume.

organic - Of, relating to, or derived from living organisms (plant or animal).

outcrop - Place where groundwater is discharged to the surface. Springs, swamps, and beds of streams and rivers are the outcrops of the water table.

outfall - Point of discharge (e.g., drain or pipe) of wastewater or other effluents into a ditch, pond, or river.

parameter - Analytical constituent; chemical compound(s) or property for which an analytical request may be submitted.

permeability - Physical property that describes the ease with which water may move through the pore spaces and cracks in a solid.

person-rem - Collective dose to a population group. For example, a dose of one rem to 10 individuals results in a collective dose of 10 person-rem.

pH - Measure of the hydrogen ion concentration in an aqueous solution. Acidic solutions have a $\mathrm{pH}$ from 0 6 , basic solutions have a $\mathrm{pH}>7$, and neutral solutions have a $\mathrm{pH}=7$.

piezometer - Instrument used to measure the potentiometric surface of the groundwater. Also, a well designed for this purpose.

plume - Volume of contaminated air or water originating at a point-source emission (e.g., a smokestack) or at a waste source (e.g., a hazardous waste disposal site).

point source - any defined source of emission to air or water such as a stack, air vent, pipe, channel or passage to a water body.

population dose - See collective dose equivalent under dose. 
process sewer - Pipe or drain, generally located underground, used to carry off process water and/or waste matter.

purge - To remove water prior to sampling, generally by pumping or bailing.

purge water - Water that has been removed prior to sampling; water that has been released to seepage basins to allow a significant part of tritium to decay before the water outcrops to surface streams and flows to the Savannah River.

Q

quality assurance (QA) - In the Environmental Monitoring System program, QA consists of the system whereby the laboratory can assure clients and other outside entities, such as government agencies and accrediting bodies, that the laboratory is generating data of proven and known quality.

quality control (QC) - In the Environmental Monitoring System program, QC refers to those operations undertaken in the laboratory to ensure that the data produced are generated within known probability limits of accuracy and precision.

$\mathbf{R}$

rad - Unit of absorbed dose deposited in a volume of material.

radioactivity - Spontaneous emission of radiation, generally alpha or beta particles, or gamma rays, from the nucleus of an unstable isotope.

radioisotopes - Radioactive isotopes.

radionuclide - Unstable nuclide capable of spontaneous transformation into other nuclides by changing its nuclear configuration or energy level. This transformation is accompanied by the emission of photons or particles.

real-time instrumentation - Operation in which programmed responses to an event essentially are simultaneous to the event itself.

reforestation - Process of planting new trees on land once forested.

regulatory compliance - Actions taken in accordance with government laws, regulations, orders, etc., that apply to Savannah River Site operations' effects on onsite and offsite natural resources and on human health; used interchangeably in this document with environmental compliance.

release - Any discharge to the environment. Environment is broadly defined as any water, land, or ambient air.

rem - Unit of dose equivalent (absorbed dose in rads $x$ the radiation quality factor). Dose equivalent frequently is reported in units of millirem (mrem) which is one-thousandth of a rem.

remediation - Assessment and cleanup of U.S. Department of Energy sites contaminated with waste as a result of past activities. See environmental restoration.

remediation design - Planning aspects of remediation, such as engineering characterization, sampling studies, data compilation, and determining a path forward for a waste site.

replicate - In the Environmental Services Section groundwater monitoring program, a second sample from the same well taken at the same time as the primary sample and sent to the same laboratory for analysis.

Resource Conservation and Recovery Act (RCRA) - Federal legislation that regulates the transport, treatment, and disposal of solid and hazardous wastes. This act also requires corrective action for releases of hazardous waste at inactive waste units.

Resource Conservation and Recovery Act (RCRA) site - Solid waste management unit under Resource Conservation and Recovery Act regulation. See Resource Conservation and Recovery Act.

retention basin - Unlined basin used for emergency, temporary storage of potentially contaminated cooling water from chemical separations activities.

RFI/RI Program - RCRA Facility Investigation/ Remedial Investigation Program. At the Savannah River Site, the expansion of the RFI Program to include Comprehensive Environmental Response, Compensation, and Liability Act and hazardous substance regulations.

routine radioactive release - Planned or scheduled release of radioactivity to the environment. 
$\mathbf{S}$

seepage basin - Excavation that receives wastewater. Insoluble materials settle out on the floor of the basin and soluble materials seep with the water through the soil column, where they are removed partially by ion exchange with the soil. Construction may include dikes to prevent overflow or surface runoff.

sensitivity - Capability of methodology or instruments to discriminate between samples with differing concentrations or containing varying amounts of analyte.

settling basin - Temporary holding basin (excavation) that receives wastewater that subsequently is discharged.

site stream - Any natural stream on the Savannah River Site. Surface drainage of the site is via these streams to the Savannah River.

source - Point or object from which radiation or contamination emanates.

source check - Radioactive source (with a known amount of radioactivity) used to check the performance of the radiation detector instrument.

source term - Quantity of radioactivity (released in a set period of time) that is traceable to the starting point of an effluent stream or migration pathway.

spent nuclear fuel - Used fuel elements from reactors.

spike - Addition, to a blank sample, of a known amount of reference material containing the analyte of interest.

stable - Not radioactive or not easily decomposed or otherwise modified chemically.

stack - Vertical pipe or flue designed to exhaust airborne gases and suspended particulate matter.

standard deviation - Indication of the dispersion of a set of results around their average.

stormwater runoff - Surface streams that appear after precipitation.

Superfund - see Comprehensive Environmental Response, Compensation, and Liability Act (CERCLA).

supernate - Portion of a liquid above settled materials in a tank or other vessel. surface water - All water on the surface of the earth, as distinguished from groundwater.

$\mathbf{T}$

tank farm - Installation of interconnected underground tanks for storage of high-level radioactive liquid wastes.

temperature - Thermal state of a body, considered with its ability to communicate heat to other bodies.

thermoluminescent dosimeter (TLD) - Device used to measure external gamma radiation.

total dissolved solids - Dissolved solids and total dissolved solids are terms generally associated with freshwater systems; they consist of inorganic salts, small amounts of organic matter and dissolved materials.

total phosphorus - When concentrations exceed 25 $\mathrm{mg} / \mathrm{L}$ at the time of the spring turnover on a volumeweighted basis in lakes or reservoirs, it may occasionally stimulate excessive or nuisance growths of algae and other aquatic plants.

total suspended particulates - Refers to the concentration of particulates in suspension in the air, irrespective of the nature, source, or size of the particulates.

transport pathway - Pathway by which a released contaminant is transported physically from its point of discharge to a point of potential exposure to humans. Typical transport pathways include the atmosphere, surface water, and groundwater.

transuranic waste - Solid radioactive waste containing primarily alpha-emitting elements heavier than uranium.

trend - General drift, tendency, or pattern of a set of data plotted over time.

turbidity - Measure of the concentration of sediment or suspended particles in solution.

$\mathbf{U}$

unspecified alpha and beta emissions - the unidentified alpha and beta emissions that are determined at each effluent location by subtracting the sum of the individually measured alpha-emitting (e.g., 
plutonium-239 and uranium-235) and beta-emitting (e.g., cesium-137 and strontium-90) radionuclides from the measured gross alpha and beta values, respectively.

\section{V}

vitrify - Change into glass.

vitrification - Process of changing into glass.

volatile organic compounds - Broad range of organic compounds, commonly halogenated, that vaporize at ambient, or relatively low, temperatures (e.g., acetone, benzene, chloroform, and methyl alcohol).

W

waste management - The U.S. Department of Energy uses this term to refer to the safe, effective management of various kinds of nonhazardous, hazardous, and radioactive waste generated on site.

waste unit - An inactive area known to have received contamination or to have had a release to the environment. water table - Planar, underground surface beneath which earth materials, such as soil or rock, are saturated with water.

weighting factor - Value used to calculate dose equivalents. It is tissue specific and represents the fraction of the total health risk resulting from uniform, whole-body irradiation that could be attributed to that particular tissue. The weighting factors used in this report are recommended by the International Commission on Radiological Protection (Publication 26).

wetlands - Lowland area, such as a marsh or swamp, inundated or saturated by surface or groundwater sufficiently to support hydrophytic vegetation typically adapted for life in saturated soils.

wind rose - Diagram in which statistical information concerning wind direction and speed at a location is summarized.

worldwide fallout - Radioactive debris from atmospheric weapons tests that has been deposited on the earth's surface after being airborne and cycling around the earth. 



\section{References}

Aadland et al., 1995 Aadland, R.K., J.A. Gellici, and P.A. Thayer, 1995, "Hydrogeologic Framework of West-Central South Carolina," Report 5, Water Resources Division, South Carolina Department of Natural Resources, Columbia, S.C.

Carlton et al., 1994 Carlton, W.H., C.E. Murphy, Jr., and A.G. Evans, 1994, "Radiocesium in the Savannah River Site Environment," Health Physics, Volume 67, Number 3, Williams \& Wilkins, Baltimore, Md.

Clarke and West, 1997 Clarke, J.S., and C.T. West, 1997, "Ground-Water Levels, Predevelopment GroundWater Flow, and Stream-Aquifer Relations in the Vicinity of the Savannah River Site, Georgia and South Carolina," U.S. Geological Survey Water-Resources Investigations Report 974197, U.S. Geological Survey, Reston, Va.

DOE, 1988 U.S. Department of Energy, 1988, External and Internal Dose Conversion Factors for Calculation of Dose to the Public, DOE/EH-0070 \& 71, Washington, D.C.

DOE, 1991 U.S. Department of Energy, 1991, Environmental Regulatory Guide for Radiological Effluent Monitoring and Environmental Surveillance, DOE/EH-0173T, National Technical Information Service, Springfield, Va.

DOE, 2002 U.S. Department of Energy, 2002, A Graded Approach for Evaluating Radiation Doses to Aquatic and Terrestrial Biota, DOE Standard, DOE-STD-1153-2002, July 2002, Washington, D.C.

DOE, 2003 U.S. Department of Energy, 2003, DOE Quality Systems for Analytical Services, Revision 0, July 2003, Office of Environmental Management, Washington, D.C.

EMS QA Plan, 2001 Savannah River Site Environmental Monitoring Section Quality Assurance Plan, 2001, WSRC-3Q1-2, Volume 3, Section 8000, Savannah River Site, Aiken, S.C.

EPA, 1986 U.S. Environmental Protection Agency, 1986, Test Methods for Evaluating Solid Waste, November 1986, SW-846, Third Edition, Washington, D.C.

EPA, 1993 U.S. Environmental Protection Agency, 1993, Data Quality Objectives Process for Superfund, EPA-540-R-93-071, Washington, D.C.

EPA, 1999a U.S. Environmental Protection Agency, 1999, "National Emission Standards for Hazardous Air Pollutants," Title 40 Code of Federal Regulations, Part 61, Washington, D.C.

EPA, 1999b U.S. Environmental Protection Agency, 1999, Cancer Risk Coefficients for Environmental Exposure to Radionuclides, Federal Guidance Report No. 13, EPA 402-R-99-001, September 1999, Washington, D.C.

EPA, 1999c U.S. Environmental Protection Agency, 1999, USEPA Contract Laboratory Program National Functional Guidelines for Organic Data Review, EPA-540/R-99/008, Washington, D.C.

EPA, 2000 U.S. Environmental Protection Agency, 2000, Guidance for the Data Quality Objectives Process for Hazardous Waste Site Investigations $(Q A / G-4 H W)$, EPA-600/R-00-007, January 2000, Washington, D.C.

EPA, 2001 U.S. Environmental Protection Agency, 2001, USEPA Contract Laboratory Program National Functional Guidelines for Inorganic Data Review, EPA-540/R-01/008, Washington, D.C.

EPA, 2002a U.S. Environmental Protection Agency, 2002, Guidance on Environmental Data Verification and Data Validation $(Q A / G-8)$, EPA-240/R-02/004, November 2002, Washington, D.C.

EPA, 2002b U.S. Environmental Protection Agency, 2002, USEPA Contract Laboratory Program National Functional Guidelines for Chlorinated Dioxin/Furan Data Review, EPA-540/R-02/003, August 2002, Washington, D.C. 
Fact Sheet, 2000 Westinghouse Savannah River Company, 2000, "Environmental Restoration," Fact Sheet, www.srs.gov/general/aboutsrs/pub rel/factsheets/hlwtf7.pdf, Savannah River Site, Aiken, S.C.

Fallaw and Price, 1995 Fallaw, W.C., and V. Price, 1995, "Stratigraphy of the Savannah River Site and Vicinity," Southeastern Geology, Vol. 35, No. 1, March 1995, pp. 21-58, Duke University, Durham, N.C.

Hamby, 1991 Hamby, D.M., 1991, Land and Water Use Characteristics in the Vicinity of the Savannah River Site (U), WSRC-RP-91-17, Savannah River Site, Aiken, S.C.

Hamby and Bauer, 1994 Hamby, D.M., and L.R. Bauer, 1994, "The Vegetation-to-Air Concentration Ratio in a Specific Activity Atmospheric Tritium Model," Health Physics, Volume 66, Number 3, Williams \& Wilkins, Baltimore, Md.

ICRP, 1979 International Commission on Radiation Protection, 1979, "Limits for the Intake of Radionuclides by Workers," Publication 30, Elmsford, N.Y.

ICRP, 1985 International Commission on Radiation Protection, 1985, "Principles of Monitoring for the Radiation Protection of the Population," Publication 43, Elmsford, N.Y.

ICRP, 1987 International Commission on Radiation Protection, 1987, "Recommendations of the International Commission on Radiation Protection," Publication 26, Elmsford, N.Y.

NRC, 1977 U.S. Nuclear Regulatory Commission, 1977, Regulatory Guide 1.109, Calculation of Annual Doses to Man from Routine Releases of Reactor Effluents for the Purpose of Evaluating Compliance with 10 CFR 50, Appendix I, Revision 1, Washington, D.C.

SCDHEC, 2001 South Carolina Department of Health and Environmental Control, 2001, "Water Classifications and Standards," South Carolina Code of Regulations, R.61-68, Columbia, S.C.

Smits et al., 1996 Smits, A.D., M.K. Harris, K.L. Hawkins, and G.P. Flach, 1996, "Integrated Hydrogeological Model of the General Separations Area, Volume 1: Hydrogeological Framework," WSRC-TR-96-0399, Revision 0, Westinghouse Savannah River Company, Aiken, S.C.

SRS Data, 1995 Environmental Protection Department Environmental Monitoring Section, 1995, Savannah River Site Environmental Data for 1994, WSRC-TR-95-077, Savannah River Site, Aiken, S.C.

SRS EM Program, 2001 Savannah River Site Environmental Monitoring Section Plans and Procedures, 2001, WSRC-3Q1-2, Volume 1, Section 1100, Savannah River Site, Aiken, S.C.

WSRC, 1991 Westinghouse Savannah River Company, 1991, National Emissions Standards for Hazardous Air Pollutants Quality Assurance Plan (U), WSRC-IM-91-60, Savannah River Site, Aiken, S.C.

WSRC, 1992 Westinghouse Savannah River Company, 1999, Quality Assurance Management Plan (WSRCRP-92-225), Revision 8, Savannah River Site, Aiken, S.C.

WSRC, 1993 Westinghouse Savannah River Company, 1993, WSRC Sitewide Records Inventory and Disposition Schedule, WSRC-IM-93-0060, Savannah River Site, Aiken, S.C.

WSRC, 2000a Westinghouse Savannah River Company, 2000, WSRC Environmental Compliance Manual, WSRC 3Q, Savannah River Site, Aiken, S.C.

WSRC, 2000b Westinghouse Savannah River Company, 2000, WSRC Quality Assurance Manual, WSRC 1Q, Savannah River Site, Aiken, S.C.

WSRC, 2000c Westinghouse Savannah River Company, 2000, WSRC Assessment Manual, WSRC 12Q, Savannah River Site, Aiken, S.C.

WSRC, 2003 Westinghouse Savannah River Company, 2003, Savannah River Site Environmental Monitoring Section Quality Assurance Plan, WSRC-3Q1-2, Section 8000), Savannah River Site, Aiken, S.C. 


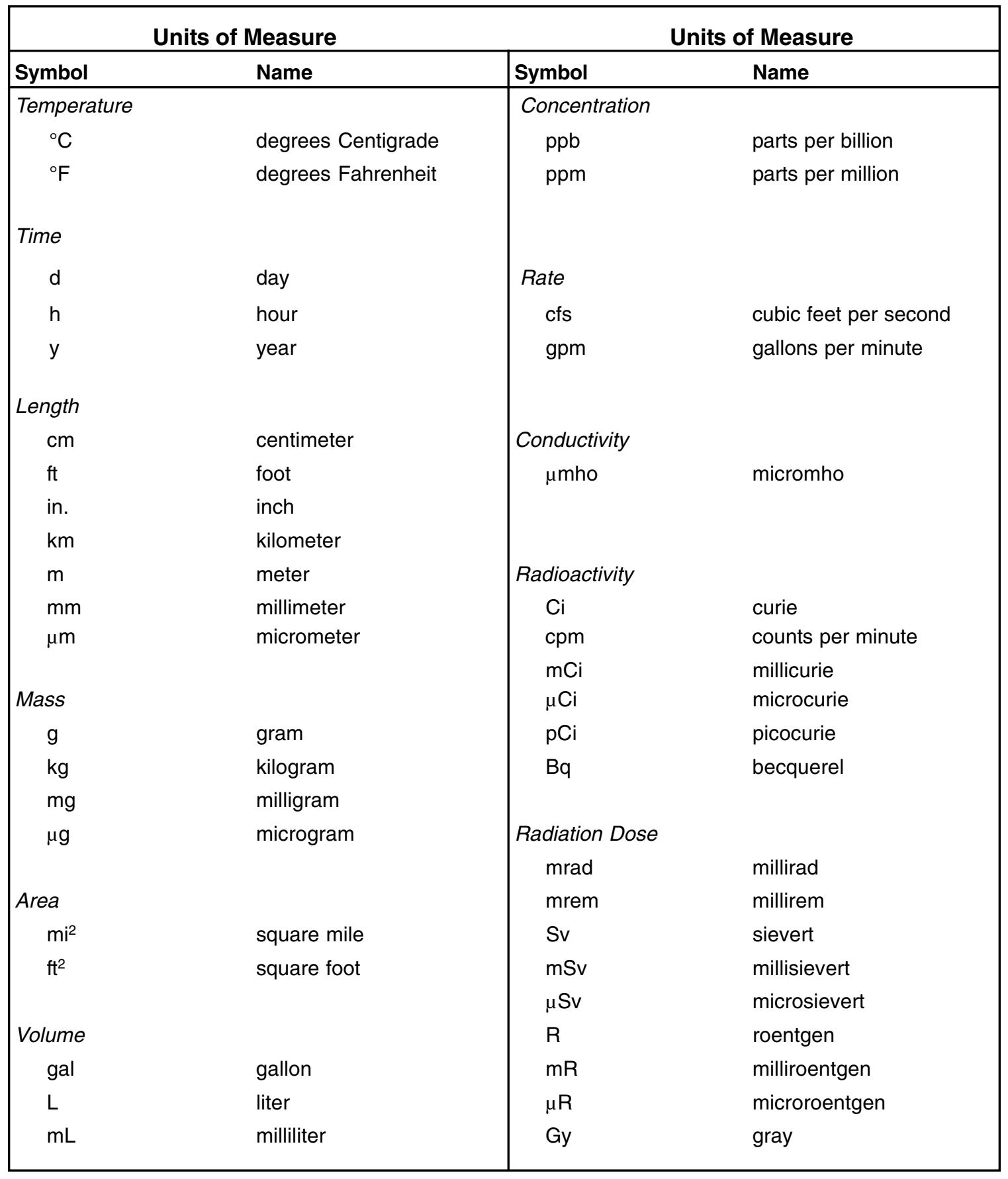




\begin{tabular}{|lcllc|}
\hline \multicolumn{5}{c}{ Fractions and Multiples of Units } \\
\hline Multiple & Decimal Equivalent & Prefix & Symbol & $\begin{array}{c}\text { Report } \\
\text { Format }\end{array}$ \\
\hline $10^{6}$ & $1,000,000$ & mega- & $\mathrm{M}$ & $\mathrm{E}+06$ \\
$10^{3}$ & 1,000 & kilo- & $\mathrm{k}$ & $\mathrm{E}+03$ \\
$10^{2}$ & 100 & hecto- & $\mathrm{h}$ & $\mathrm{E}+02$ \\
10 & 10 & deka- & $\mathrm{da}$ & $\mathrm{E}+01$ \\
$10^{-1}$ & 0.1 & deci- & $\mathrm{d}$ & $\mathrm{E}-01$ \\
$10^{-2}$ & 0.01 & centi- & $\mathrm{C}$ & $\mathrm{E}-02$ \\
$10^{-3}$ & 0.001 & milli- & $\mathrm{m}$ & $\mathrm{E}-03$ \\
$10^{-6}$ & 0.000001 & micro- & $\mu$ & $\mathrm{E}-06$ \\
$10^{-9}$ & 0.000000001 & nano- & $\mathrm{n}$ & $\mathrm{E}-09$ \\
$10^{-12}$ & 0.000000000001 & pico- & $\mathrm{p}$ & $\mathrm{E}-12$ \\
$10^{-15}$ & 0.0000000000000001 & femto- & $\mathrm{f}$ & $\mathrm{E}-15$ \\
$10^{-18}$ & 0.0000000000000000001 & atto- & $\mathrm{a}$ & $\mathrm{E}-18$ \\
\hline
\end{tabular}

\begin{tabular}{|lll|}
\hline \multicolumn{3}{|c|}{ Conversion Table (Units of Radiation Measure) } \\
\hline Current System & Systéme International & Conversion \\
\hline curie $(\mathrm{Ci})$ & becquerel $(\mathrm{Bq})$ & $1 \mathrm{Ci}=3.7 \times 10^{10} \mathrm{~Bq}$ \\
rad (radiation absorbed dose) & gray (Gy) & $1 \mathrm{rad}=0.01 \mathrm{~Gy}$ \\
rem (roentgen equivalent man) & sievert $(\mathrm{Sv})$ & $1 \mathrm{rem}=0.01 \mathrm{~Sv}$ \\
\hline
\end{tabular}

\begin{tabular}{|lll|lll|}
\hline \multicolumn{5}{c|}{ Conversion Table } \\
\hline Multiply & By & To Obtain & Multiply & By & To Obtain \\
\hline $\mathrm{in.}$ & 2.54 & $\mathrm{~cm}$ & $\mathrm{~cm}$ & 0.394 & $\mathrm{in}$. \\
$\mathrm{ft}$ & 0.305 & $\mathrm{~m}$ & $\mathrm{~m}$ & 3.28 & $\mathrm{ft}$ \\
$\mathrm{mi}$ & 1.61 & $\mathrm{~km}$ & $\mathrm{~km}$ & 0.621 & $\mathrm{mi}$ \\
$\mathrm{lb}$ & 0.4536 & $\mathrm{~kg}$ & $\mathrm{~kg}$ & 2.205 & $\mathrm{lb}$ \\
$\mathrm{liq} \mathrm{qt}-$ U.S. & 0.946 & $\mathrm{~L}$ & $\mathrm{~L}$ & 1.057 & $\mathrm{liq}$ qt-U.S. \\
$\mathrm{ft}^{2}$ & 0.093 & $\mathrm{~m}^{2}$ & $\mathrm{~m}^{2}$ & 10.764 & $\mathrm{ft}^{2}$ \\
$\mathrm{mi}^{2}$ & 2.59 & $\mathrm{~km}^{2}$ & $\mathrm{~km}^{2}$ & 0.386 & $\mathrm{mi}^{2}$ \\
$\mathrm{ft}^{3}$ & 0.028 & $\mathrm{~m}^{3}$ & $\mathrm{~m}^{3}$ & 35.31 & $\mathrm{ft}^{3}$ \\
$\mathrm{~d} / \mathrm{m}$ & 0.450 & $\mathrm{pCi}$ & $\mathrm{pCi}$ & 2.22 & $\mathrm{~d} / \mathrm{m}$ \\
$\mathrm{pCi}$ & $10^{-6}$ & $\mu \mathrm{Ci}$ & $\mu \mathrm{Ci}$ & $10^{6}$ & $\mathrm{pCi}$ \\
$\mathrm{pCi} / \mathrm{L}$ (water) & $10^{-9}$ & $\mu \mathrm{Ci} / \mathrm{mL}$ (water) & $\mu \mathrm{Ci} / \mathrm{mL}$ (water) & $10^{9}$ & $\mathrm{pCi} / \mathrm{L}$ (water) \\
\hline
\end{tabular}

